\title{
Sarvāstivāda Buddhist Theories of Temporality and the Pātañjala Yoga Theory of Transformation (parināma)
}

\author{
Philipp A. Maas ${ }^{1} \mathbb{C}$
}

Accepted: 12 September 2020/Published online: 29 October 2020

(C) The Author(s) 2020

\begin{abstract}
This article discusses a peculiar Sānkhya-Yoga theory of transformation (parināma) that the author of the Pātañjalayogaśāstra created by drawing upon Sarvāstivāda Buddhist theories of temporality. In developing his theory, Patañjali adaptively reused the wording in which the Sarvāstivāda theories were formulated, the specific objections against these theories, and their refutations to win the philosophical debate about temporality against Sarvāstivāda Buddhism. Patañjali's approach towards the Sarvāstivāda Buddhist theories was possible, even though his system of Yoga is based on an ontology that differs considerably from that of Sarvāstivāda Buddhism because both systems share the philosophical view that time is not a separate ontological entity in itself. Time is a concept deduced from change in the empirical world. This agreement results from the common philosophical orientation of Sarvāstivāda Buddhism and Yoga, which takes the phenomenon of experience as the basis of philosophical enquiry into the structure of the world. The intention that guided Patañjali's adaptive reuse was twofold. On the one hand, he aimed at winning the debate with Sarvāstivāda Buddhism about how the problem of temporality can be solved. He thus integrated four mutually exclusive theories on
\end{abstract}

The present article is based on the lecture "Sarvāstivāda Buddhism and the Yoga of Patañjali" presented on 23 August 2014 at the 17. Congress of the International Association of Buddhist Studies in Vienna (Maas 2014). In a subsequent discussion, Kei Kataoka was kind enough to draw my attention to the following work of Takagi Shingen, which is written in Japanese and therefore unfortunately not accessible to me: Takagi Shingen, Koten Yōga Taikei no Kenkyū (A Study of the Classical Yoga System). Takagi Shingen Chosaku shū (Collected Works of Takagi Shingen). Vol. 1. Kyōto: Hōzōkan, 1991. Many thanks are due to Eli Franco, Elisa Freschi, Isabelle Ratié and Dominik Wujastyk for their insightful comments upon drafts of this article that led to several revisions and clarifications. I am also indebted to two anonymous reviewers for their valuable suggestions for additional improvements.

Philipp A. Maas

philipp.a.maas@gmail.com

1 Institut für Indologie und Zentralasienwissenschaften, University of Leipzig, Schillerstr. 6, 04109 Leipzig, Germany 
temporality into a single theory of transformation of properties (dharma) involving a second-level and a third-level theory on the transformation of the temporal characteristic mark (lakșaṇa) and on the transformation of states (avasthā), respectively. On the other hand, Patañjali intended to achieve philosophical clarification regarding the question of how exactly properties relate to their underlying substrate in the process of transformation of the three constituents or forces (guna) sattva, rajas and tamas of matter (pradhāna) that account for all phenomena of the world except pure consciousness (purușa). Patañjali's theory of transformation is thus of central importance for his Sānkhya ontology, according to which the world consists of 25 categories or constituents (tattva), i.e., of primal matter (prakrti) and its transformations and pure consciousness.

Keywords Ontology · Temporality · Pātañjala Yoga · Yoga philosophy · Sārvāstivāda Buddhism · Abhidharma

\section{Introduction}

This article discusses a peculiar Sānkhya-Yoga theory of transformation (parināma) that the author of the Pātañjalayogaśāstra created by drawing upon Sarvāstivāda Buddhist theories of temporality. In developing his theory, Patañjali adaptively reused the wording in which the Sarvāstivāda theories were formulated, the specific objections against these theories, and their refutations to win the philosophical debate about temporality against Sarvāstivāda Buddhism. ${ }^{1}$ Patañjali's approach towards the Sarvāstivāda Buddhist theories was possible, even though his system of Yoga is based on an ontology that differs considerably from that of Sarvāstivāda Buddhism because both systems share the philosophical view that time is not a separate ontological entity in itself. Time is a concept deduced from change in the empirical world. ${ }^{2}$ This agreement results from the common philosophical orientation of Sarvāstivāda Buddhism and Yoga, which takes the phenomenon of experience as the basis of philosophical enquiry into the structure of the world. As was already argued by Braj M. Sinha (1983, p. 6f.), both philosophical schools identify the structure of temporality with the structure of subjectivity.

The intention that guided Patañjali's adaptive reuse was twofold. On the one hand, he aimed at winning the debate with Sarvāstivāda Buddhism about how the

\footnotetext{
1 "The concept of reuse comprises four main aspects, viz. (1.) the involvement of at least one consciously acting agent, who, (2.) in order to achieve a certain purpose, (3.) resumes the usage (4.) of a clearly identifiable object after an interruption in its being used. The attribute 'adaptive' presupposes that the reusing person pursues a specific purpose by adapting something already existent to his or her specific needs. The reused object has to be identifiable as being reused, ..." Freschi and Maas (2017, p. 13).

2 See Ratié (forthcoming) $§ 7$. According to Yoga, which takes the world as real and independent of mind or consciousness, time is not an entity but merely a mental construct: "This 'time,' although it has no reality [and is just] a creation of the mind resulting from verbal cognitions, appears as if it had a real nature to worldly people whose views are agitated." sa khalv ayam kālo vastuśūnyo 'pi buddhinirmāṇah śabdajñānānupātī laukikānāṃ vyutthitadarśanānām vastusvarūpa ivāvabhāsate (PYŚ 3.52, ed. Āgāse, pp. 171, 1. 1-3). Although time is a mental construct, the present moment (kșaṇa) is real; see also Rospatt (1995, p. 97).
} 
problem of temporality can be solved. He thus integrated four mutually exclusive theories on temporality into a single theory of transformation of properties (dharma) involving a second-level and a third-level theory on the transformation of the temporal characteristic mark (lakșaṇa) and on the transformation of states (avasthā), respectively. On the other hand, Patañjali intended to achieve philosophical clarification regarding the question of how exactly properties relate to their underlying substrate in the process of transformation of the three constituents or forces (guna) sattva, rajas and tamas of matter (pradhāna) that account for all phenomena of the world except pure consciousness (purușa). Patañjali's theory of transformation is thus of central importance for his Sānkhya ontology, according to which the world consists of 25 categories or constituents (tattva), i.e., of primal matter (prakrti) and its transformations and pure consciousness.

The existence of a parallel between theories of temporality in Sarvāstivāda Buddhism and the theory of transformation in Pātañjala Yoga has long been known. In the early phase of Indological research, it was highlighted, for example, by Fëdor Ščerbatckoj (also known as Theodore Stscherbatsky) (1923, pp. 43-47) and by Louis de La Vallée Poussin (1937, pp. 237-239). The exact relationship between Sarvāstivāda theories of temporality and Pātañjala Yoga has remained, however, largely unexplored. ${ }^{3}$ In 1973, Erich Frauwallner judged the relationship between the locus classicus of Sarvāstivāda temporality, which occurs in all three vibhāṣa compendia, to Pātañjala Yoga in the context of his discussion of the Sarvāstivāda in the following way: "[Ein] Abklatsch dieses Textes hat schließlich auch seinen Weg in das Yogabhāṣyam gefunden."4

According to Frauwallner, a poor copy or an inferior imitation ("ein Abklatsch") of the Sarvāstivāda theories of temporality has found its way into the Yogabhāṣya, a text that Frauwallner thought to be a commentary on the Yogasütra composed by an author named Vyāsa around the year $500 \mathrm{CE} .^{5}$ However, as the present author has shown based on observations made by earlier scholars (Jacobi 1929, p. 584, Kane 1934, p. 392f., Raghavan 1938-1939, Bronkhorst 1985), the text of the Yogabhāsya is probably only a portion of a more comprehensive work, namely the Pātañjalayogaśāstra, in which the Yogasūtra and the Yogabhāṣya appear as an integrated literary composition of a single author whose name was Patañjali. ${ }^{6}$ Independently from the authorship question concerning the Yogasütra-s and its bhāsya, Frauwallner overlooked that not only the bhāsya-part of the Pātañjalayogaśāstra but also yogasütra-s 3.13 and 4.12 indicate that Patañjali was familiar with Sarvāstivāda theories of temporality. ${ }^{7}$

\footnotetext{
${ }^{3}$ Neither Chakravarti (1951, pp. 93-99) nor Yamashita (1994, pp. 40-64) investigated the relationship between the four Sarvāstivāda theories of temporality and their reuse in the Pātañjalayogaśāstra in detail.

4 Frauwallner (1973, p. 100, n. 11).

5 Frauwallner (1953, p. 288).

6 See Maas (2006, pp. xii-xix) and Maas (2013, pp. 57-65).

7 Sūtra 3.13 contains the two terms lakșaṇa and avasthā that are characteristic for the Sarvāstivāda theories attributed to Ghoșaka, Vasumitra and Buddhadeva (see below, sections The Difference in Characteristic Marks, The Difference in the State and Relative Difference), and Sūtra 4.12 is heavily indebted to the characteristic Sarvāstivāda teaching that entities exist in reality not only in the present but also in the past and future time. "[A thing] exists essentially [even] when it is past or present because
} 
Frauwallner's assessment of Patañjali's degree of philosophical creativity had changed over time. Twenty years before the publication of the just-quoted later verdict, he had remarked more positively on the relationship of Sarvāstivāda Buddhism and Pātañjala Yoga in the first volume of his Geschichte der indischen Philosophie (1953). There, he wrote about inspirations (“Anregungen”, p. 416) and details in the implementation of thought ("Einzelheiten in der Durchführung der Gedanken", p. 416) that Vyāsa, the alleged author of the Yogabhāṣya, had received from Sarvāstivāda Buddhism. ${ }^{8}$

Sinha, in contradistinction to Frauwallner and without reference to his work, did not recognise a historical dependency of Patañjali's Yoga theory on the conceptions of temporality of Sarvāstivāda Buddhism and argued in favour of a "parallelism" resulting from similar philosophical solutions of the problem of temporality in Sarvāstivāda Buddhism and early Sānkhya-Yoga. A further factor that increased the degree of similarity of philosophical positions may have been, according to Sinha,

a history of interaction between the two schools that one can discern here, even though from the very nature of the case and the general paucity of historical data one is not able to substantiate it through independent sources. ${ }^{9}$

Sinha describes a possible scenario, according to which similarities between Pātañjala Yoga and Sarvāstivāda Buddhism result from similar but independently derived solutions of the same philosophical problem in two systems of thought that both take a subjective philosophical perspective. Once this solution was discovered, early Sarvāstivādins and pre-Pātañjala Yogins may have entered into philosophical discourses leading to further harmonization of their respective positions. Due to historical contingency, this hypothesis cannot be substantiated with written sources.

It is, however, not the case that written sources for the history of pre-Pâtañjala Sānkhya-Yoga are entirely missing, even if the picture that can be drawn from sources such as the Mahābhārata, the Carakasamhitā, the older and middle Upanișads and others is incomplete. Neither of these sources attests a theory of temporality similar to the Sarvāstivāda Buddhist theories discussed below in preclassical Sānkhya currents of thought.

The various views on time within the history of Sānkhya philosophy starting from the classical period are the subject of a comprehensive forthcoming study by Isabelle Ratié. Ratié characterises the views on time in the Sānkhyakārikāas by Iśvarakṛ̣̣na and its earlier commentaries, i.e. the Suvarṇasaptativyākhyā (only

\footnotetext{
Footnote 7 continued properties are subject to different times" atītānāgatam svarūpato 'sty adhvabhedād dharmānām (YS 4.12, ed. Āgāśe, p. 186, 1. 3f.).

${ }^{8}$ Frauwallner (1953, pp. 412-416). Similarly, Johannes Bronkhorst (2011, pp. 59) assumed that Patañjali "borrowed" his theories of temporality from Sarvāstivāda Buddhism.

9 Sinha (1983, p. 132).
} 
preserved in Chinese translation), Sānkkhyavrtti, Sān்khyasaptativrtti, Gaudapādabhāṣya and Mātharavṛtti, as

not so much concerned with defining time as they are with denying its causality; they do so by asserting that time has no existence over and above the three constitutive elements of reality acknowledged in Sāmphya ... . ${ }^{10}$

According to Ratié's analysis, all early commentaries on the Sänhhkyakārikā-s are based on the same interpretation of stanza 61 . And this

... early interpretation of the $S[\bar{a}$ ṅkhya $] \mathrm{K}[\bar{a}$ rikā $]$ seems to have offered little more than an argument of authority regarding the ontological and causal status of time (namely: since the S[ānkhya]K[ārikā] do[es] not mention kāla as a separate item in the enumeration of categories, it cannot be one); and while emphatically denying $k \bar{a} l a$ 's distinct reality or causality, it did not offer any clear definition of it. ${ }^{11}$

Taking into consideration that the classical Sānkhya position on time differs fundamentaly from that of Pātañjala Yoga, it is unlikely that the specific solution for the problem of temporality in Sarvāstivāda Buddhism and Pātañjala Yoga developed independently from each other. The high degree of conceptional, terminological and literal agreement between the Sarvavāstivāda theories as reported in Vasubandhu's Abhidharmokośabhāṣya and the Pātañjalayogaśāstra even virtually rules out the possibility of parallel developments. Taking into consideration the chronology of the pertinent Sarvāstivāda theories and the Pātañjalayogaśāstra and the fact that Patañjali possibly reused Vasubandhu's Abhidharmakośabhāsya also at other instances, ${ }^{12}$ it is highly probable that Frauwallner judged the historical relationship between the Sarvāstivāda theories of temporality and Patañjali's theory of transformation correctly.

Frauwallner's later pejorative verdict on the philosophical quality of Patañjali's adaptation of the Buddhist theories is, however, problematic. Patañjali did not copy the Buddhist theories poorly, but he adaptively reused them in a new theory meant to outmatch rival Buddhist theories and to defend the Sānkhya theory of transformation against possible objections. In support of this assertion, the present article initially introduces the Sarvāstivāda Buddhist theories in their philosophical and historical contexts. After that, the article will discuss Patañjali's adaptive reuse based on a close analysis of text passages from the Pātañjalayogaśāstra and from Vasubandhu's Abhidharmakośabhāṣya, which is the oldest formulation of the Sarvāstivāda theories preserved in Sanskrit, and with additional sources.

\footnotetext{
${ }^{10}$ Ratié forthcoming: $\S 1$.

11 Ratié forthcoming: $\S 1$.

12 See O’Brien-Kop (2018, p. 146).
} 


\section{Sarvāstivāda Buddhist Ontology and the Problem of Temporality}

According to Sarvāstivāda Buddhism, all conditioned factors (samskṛtadharma) that make up the empirical world are momentary. The factors are active only for the tiny instance of time that is necessary to exercise birth (jāti), duration (sthiti), decay (jarā), and vanishing (anityatā $).{ }^{13}$ Within the short time of their activity, the factors cause the arising of related factors that are similar to their predecessors, which again cause further factors and so on. In this way, the seeming continuous empirical world is, in reality, a stream of discrete momentary factors, each of which is active only briefly. $^{14}$

Sarvāstivāda combines its doctrine of momentariness with the teaching that conditioned factors exist in reality, not only in the present time but also in the past and the future, without acknowledging the existence of time as a separate transcendental or empirical entity serving as a container of the factors. ${ }^{15}$ The combination of the two peculiar doctrines led to philosophical questions concerning the exact nature of momentary conditioned factors and their reality throughout all three times. Already the three vibhāṣa compendia that are preserved in Chinese translations contain four alternative theories on temporality that are meant to answer this question in their specific ways. Two of these compendia ascribe these theories to the four Buddhist masters Dharmatrāta, Ghoșaka, Vasumitra and Buddhadeva. ${ }^{16}$

As was first noticed by Frauwallner, the four theories appear in two vibhāṣa compendia as doxographical appendices. This may indicate that they were developed sometime before the composition of the vibhạsa $\bar{a}$ compendia, which is difficult to date. Based on the information provided in Willemen et al. (1998, p. 232), a period from the middle of the first to the middle of the second century CE appears to be a viable learned guess. According to Johannes Bronkhorst (2018, p. 125), the earliest vibhāṣā compendia are possibly even two hundred years older and reach back to the time of the grammarian Patañjali, who lived in the middle of the second century BCE. In any case, they are considerably older than the Pātañjalayogaśāstra, which was composed around the year $400 \mathrm{CE}^{17}$

It should, however, not go without notice that in the vibhassa $\bar{a}$ compendia the four alternative theories appear in a systematic sequence which is based on philosophical considerations. Initially, a theory is presented in which temporality is entirely intrinsic to factors. The sequence leads, via two intermediate positions, to a theory in which temporality is exclusively the result of the factors' mutual relationship.

\footnotetext{
13 See Willemen et al. (1998, p. 24).

14 See Rospatt (1995, pp. 49-53).

15 See Sinha (1983, p. 91).

16 According to Collett Cox (1995, p. 154, n. 30), the four theories are found in similar formulations in the following works: *Āryavasumitrabodhisattvasangītiśāstra, *Vibhāṣāśāstra, *Abhidharmavibhāṣāśāstra, *Mahāvibhāṣāśāstra, Vasubandhu's Abhidharmakośabhāṣya, Yaśomitra's Sphutārthā Abhidharmakoșavyākhyā, Sañghabhadra's *Nyāyānusāraśāstra, Abhidharmadīpa and Śāntarakșita's Tattvasamgraha. This list can be supplemented with Dharmatrāta's *Samyuktābhidharmahrdaya (Dessein 2007, p. 335). On the vibhāṣa compendia in general, see Willemen et al. (1998, p. 232).

17 On the dating of the Pātañjalayogaśāstra, see Maas (2013, p. 65) f. and the section "Dating" in Maas forthcoming.
} 
Thus the four positions' sequence of presentation does not necessarily correspond to the chronology of their development. ${ }^{18}$ Regardless of whether the author-compilers of the vibhāsa $\bar{a}$ compendia invented or reformulated the four theories in such a way that they fitted their philosophical program, the Sarvāstivāda theories are still much older than Patañjali's work on Yoga.

Since the Pātañjalayogaśāstra is the oldest attestation of a Sānkhya theory comparable to the theories of Sarvāstivāda Buddhism, it is virtually sure that Patañjali drew upon the Sarvāstivāda theories when he developed his theory of transformation of matter. The degree of literary agreement between Patañjali's theory and the four Sarvāstivāda theories in Vasubandhu's Abhidharmakośabhāṣya indicates that Patañjali may even have used this same work. ${ }^{19}$ A common source for the respective theories in Sarvāstivāda Buddhism and Yoga is thus by far the less likely explanation for textual and conceptual agreements in the two systems of thought. $^{20}$

The Abhidharmakośabhāsya is an auto-commentary on the Abhidharmakośakārikā-s that Vasubandhu composed in the second half of the fourth century CE. ${ }^{21}$ It contains the oldest formulation of the Sarvāstivāda theories of the reality of all conditioned factors throughout the three times preserved in Sanskrit. Vasubandhu adopted the exposition of the four theories from the *Mahāvibhāsāśāstra and combined each of the four attributions of authorship, which in his exemplar occur at the end of the section describing the theories, into the running text of his work. ${ }^{22}$ Later authors, like Sanghabhadra, a younger contemporary of Vasubandhu who criticised the Abhidharmakośabhāsya from the perspective of

\footnotetext{
18 On the ahistorical nature of Indian doxographical writing in general, see Bouthillette (2020, pp. 1-24).

19 See below, Tables 1, 2 and 3 and Wujastyk (2018, p. 40), referencing Maas (2014).

${ }^{20}$ Chakravarti (1951, p. 98) thought that the direction of influence cannot be determined with certainty. His hesitation to accept that the Pātañjalayogaśāstra reused the Sarvāstivāda theories may partially be explained from the fact that the Sanskrit formulation of the theories in the Abhidharmakośabhāsya was not accessible to him. He thus could not assess the degree of literal agreement between the Abhidharmakośabhāṣya and the Pātañjalayogaśāstra. Moreover, the relative chronology of the two works was at his time not yet as accurately established as it is now.
}

21 Eli Franco and Karin Preisendanz (2010, p. XVI), who interpreted data highlighted by Lambert Schmithausen (1992), argued convincingly for dating Vasubandhu to the time between 320 and 400 CE. More recently, Florin Deleanu (2019) suggested a dating of Vasubandhu to the time between 350 and 430, but unfortunately, he ignored the compelling arguments of Franco and Preisendanz. An additional argument in favour of dating Vasubandhu to the time proposed by Franco and Preisendanz is the fact that the post-Vasubandhu Pātañjalayogaśāstra is quoted in Vātsyāyana's Nyāyabhāṣya (see below, note 71). This work was, according to Franco and Preisendanz (1995), composed at ca. $450 \mathrm{CE}$, or, according to Preisendanz (2018, p. 183, n.112), in "the first half of the fifth century." If one accords a period of ca. 20 years for the time in which a work receives the prominence that is necessary for being received in a work of a rival philosophical school, the following dates appear as reasonable estimations, considering that Vasubandhu authored the Abhidharmakośabhāşya when he had embraced Yogācāra views (see Kritzer 2005, p. xxviii and Franco 2017, n. 5; Changwhan Park (2014) questions, however, that Vasubandhu betrays specific Yogācāra views in the Abhidharmakośabhāṣya): Abhidharmakośabhāṣya ca. 360-380, Pātañjalayogaśāstra ca. 380-400, Nyāyabhāṣya ca. 420-440. On the life, works, and philosophical orientation of Vasubandhu, see Kritzer (2019).

22 See Dessein (2007, p. 339). 
orthodox Sarvāstivāda in his *Nyāyānusāraśāstra, followed Vasubandhu's formulation of the four Sarvāstivāda theories. ${ }^{23}$

Although the Abhidharmakośabhāsya is not the oldest available source of the four Sarvāstivāda theories under discussion, it suggests itself for a comparison with the Pātañjalayogaśāstra for several reasons. First, the Abhidharmakośabhāṣya is preserved in Sanskrit, whereas earlier attestations are only preserved in Chinese translation. This makes it impossible for the present author to consult them in their original language. ${ }^{24}$ More importantly, choosing the Abhidharmakośabhāsya for a comparison with the Pātañjalayogaśāstra allows for a comparison of the exact wording of the respective text passages in their original language. Secondly, both works belong to a comparable literary genre, i.e., they consist of a base text, i.e., the Abhidharmakośakārikā-s and the Yogasütra-s, respectively, which are commented upon and elaborated in the second layer of text, an auto-commentary called bhāsya. ${ }^{25}$ Finally, also the general approach of Vasubandhu and Patañjali towards the literature of their respective traditions appears to be at least comparable. The Abhidharmakośabhāsya "is based on the Abhidharma system as it had been systematized by Dharmaśreșţhin and revised and enlarged by Upaśānta and Dharmatrāta." 26 In his summary Vasubandhu voiced critique of Sarvāstivāda positions from a Sautrāntika perspective and based on his philosophical views that become apparent most of all in the ninth chapter of his work, in which Vasubandhu deals with the refutation of the existence of a permanent self. Patañjali's work is similar in that it is also based on earlier works (in this case now lost works of Sānkhya orientation), among which the Saștitantra by Vārṣaganya appears to have figured prominently. ${ }^{27}$ Besides, Patañjali adaptively reused various Buddhist sources. $^{28}$

\section{The Difference in the Mode of Being}

Vasubandhu ascribed the first temporal Sarvāstivāda theory to the Buddhist master Dharmatrāta, who tried to solve the problem of temporality by assuming that a factor (dharma) changes its mode of being (bhâva) when it passes through time, without, however, losing its identity. The passage Vasubandhu devoted to the exposition of Dharmatrāta's theory reads as follows:

\footnotetext{
23 See Dessein (2007, p. 337).

24 According to Dessein (2007, p. 336), the older of the two Chinese translations of the Abhidharmakośa by Paramārtha does not contain the passage under discussion in the present article. An anonymous reviewer of the present article informed me, however, that this is not the case. Paramārtha's version does contain the section under discussion.

25 On the authorship of the Pātañjalayogaśāstra, see Maas (2013, pp. 57-68).

26 Willemen et al. (1998, p. 270).

27 In his Tattvavaiśáradī (p. 187, 1. 28 ff.), Vācaspatimiśra identified a quotation in PYŚ 4.13 as a quotation from the Saștitantra. Patañjali himself ascribed a text passage that he cited (PYŚ 2.55, p. 116, 1. 7) to the Sānkhya teacher Jagīṣavya.

28 See Wujastyk (2018) and O’Brien-Kop (2018).
} 
The venerable Dharmatrāta claimed a difference in the mode of being. He reportedly said: "A conditioned factor (dharma) changes its mode of being, not its being an entity (dravya), while proceeding in the [three] times. Like a vessel made of gold that has been destroyed and made into something different changes its shape (samsthāna) and not its colour. And like milk when transforming into yoghurt loses its flavour, potency, and modified flavour but not its colour. In the same way, also a conditioned factor that comes from the future time to the present time gives up the future mode of being, but not its being an entity. In the same way, when it moves from the present to the past, it gives up its present mode of being, not its mode of being an entity."

bhāvānyathiko bhadantadharmatrātah. sa kilāha: "dharmasyādhvasu pravartamānasya bhāvānyathātvam bhavati na dravyānyathātvam. yathā suvarṇabhājanasya bhittvānyathā kriyamāṇasya samsthānānyathātvam bhavati na varṇānyathātvam. yathā ca kșīram dadhitvena pariṇamad rasavīryavipākān parityajati na varṇam. evam dharmo 'py anāgatād adhvanaḥ pratyutpannam adhvānam āgacchann anāgatabhāvam jahāti na dravyabhāvam. evam pratyutpannād atītam adhvānam gacchan pratyutpannabhāvam jahāti na dravyabhāvam” iti (AKBh 5.25; ed. Pradhan, p. 296, lines 10-15).

The interpretations of Dharmatrāta's position within the camp of Vaibhāṣika Sarvāstivāda varied in the course of history. In earlier times, Dharmatrāta's view appears to have been entirely accepted since two out of the three preserved vibhāsa $\bar{a}$ compendia do not voice any criticism. ${ }^{29}$ The *Mahāvibhāṣaśāstra objects, however, that a difference between the mode of being (bhāva) and the intrinsic nature (svabhāva) of a factor is difficult to maintain. ${ }^{30}$ If the mode of being of a factor would be identical to its intrinsic nature, a factor, while passing from one time to the next, would assume a new nature or identity, and could, accordingly, not remain the same factor in all three times. ${ }^{31}$

Vasubandhu dismissed Dharmatrāta's theory for a different reason. He thought it to be mostly identical to the philosophical system of Sānkhya that he refutes elsewhere in his work. ${ }^{32}$ Thus for Vasubandhu, Dharmatrāta's theory presupposes the existence of a permanent substrate, which violates the just-mentioned Buddhist theory of the momentariness of all conditioned factors. However, the Saravāstivāda

\footnotetext{
29 See Frauwallner (1973, p. 101).

30 See Dessein (2007, p. 333).

31 "To have a svabhāva is to exist in a primary sense, to be unique, in no sense whatsoever be something else, and the svabhāva is that characteristic which is applicable solely to that entity ..." (Williams 1981, p. 243). See also Kamalaśîla's specification of Dharmatrāta's position: "Otherwise the undesirable consequence arises that [a factor] is one in the future, another one in the present and [again] another one in the past." anyathānyo evānāgato* 'nyo vartamāno 'nyo 'tīta iti prasajyate (Tattvasamgrahapañjikā p. 504, 1. 12). Variant: *evānāgato] emended from evānāgate in Krishnamacharya's edition. The correct reading is found in Dwārikādās Śāstrī’s edition (p. 430, 1. 20).

32 The same verdict appears in the commentary on the Abhidharmadīpa called Vibhāsāprabhāvrtti, which dismisses the position as being that of the Sānkhya teacher Vārșagaṇya (Abhidharmadīpa p. 159, 1. 14).
} 
scholar Sanghabhadra, a contemporary of Vasubandhu, did not characterise Dharmatrāta's theory as crypto-Sānkhya and refuted this criticism as unfounded. ${ }^{33}$ Dharmatrāta's theory accordingly remained a viable alternative at least in some circles of Sarvāstivāda Buddhisms until the late fourth century.

Outside Buddhism, the view that a substance is permanent is, for example, attested in the Vyākaranamahābhāṣya of the grammarian Patañjali (ca. 150 BCE), who discussed the relationship between an impermanent (anitya) shape (ākrti) and its carrier, a permanent (nitya) substance (dravya), by drawing upon the example of a piece of gold that may be transformed into various forms. ${ }^{34}$

If, however, Dharmatrāta was a Sarvāstivādin, his theory could not violate the axiom of the momentariness of all conditioned factors. His theory, therefore, did not imply the existence of a permanent substrate that remains identical in time while its properties change. The original intention of Dharmatrāta's theory becomes clear if one takes a closer look at Dharmatrāta's examples, in which the two words "shape" (samsthāna) and "colour" (varna) refer to the two aspects of visible matter (rüpa) that make conditioned material factors recognizable as individual entities. ${ }^{35}$ The choice of these two terms indicates that in Dharmatrāta's first example the golden vessel is indeed meant to be a material conditioned factor that is subject to momentariness. The golden vessel loses one aspect of its identity, i.e., its shape, but it preserves another aspect, namely its colour. Also in Dharmatrāta's second example - the transformation of milk into yoghurt - the colour of milk is preserved in transformation, whereas the medical qualities consisting of flavour, potency, and modified flavour change. ${ }^{36}$ Both processes are comparable to the travel of a factor in time in so far as in changing its time a dharma loses one of its aspects, i.e., the mode of being. The same factor preserves, however, all aspects of its identifiability as an individual unit. In this interpretation, Dharmatrāta's theory is indeed a fully developed Sarvāstivāda theory of temporality that explains how momentary factors exist throughout the three times. Being present, past and future are for Dharmatrāta special modal properties of momentary entities, just like colour and form are properties of what appears as durable entities in everyday experience. Temporality, accordingly, does not affect the existence of a factor as an individual entity $(\text { dravya })^{37}$

Dharmatrāta's theory was, however, susceptible to misinterpretation, since the word dravya that Dharmatrāta used to refer to an identifiable entity may be used with a different meaning to refer to a substrate, which, as a changeable but durable

\footnotetext{
33 See Schayer (1938, p. 31f., n. 1) and Cox (1995, p. 140).

34 "For the substance is permanent, the form is impermanent" dravyam hi nityam äkrtir nityā. (Mahābhāṣya 1.1.1, p. 7, 1. 11 f.). Many thanks to Isabelle Ratié for reminding me of this passage. See also Halbfass (1992, p. 91).

35 "Form is twofold, [consisting of] colour and shape." rūpam dvidhā, varṇaḥ saṃsthānam ca (AK 1.10a ed. Pradhan, p. 6, 1. 8f.).

36 See Maas (2018b, p. 546f.).

37 For a similar interpretation of Dharmatrāta's theory, see Sinha (1983, p. 128).
} 
entity common to all phenomena, carries properties through time ${ }^{38}$ especially when dravya as something enduring is opposed to a changeable mode of being (bhâva). In this misinterpretation, Dharmatrāta's theory becomes similar to the Sānkhya theory of transformation of a single persistent substance. ${ }^{39}$ As will be discussed in more detail below, Patañjali employed this similarity to adaptively reuse Dharmatrāta's theory by a slight reformulation of its wording which involves significant semantic changes concerning the terms dharma and dravya. These changes instantiate the ontological disagreement between Yoga and Sārvāstivāda Buddhism. ${ }^{40}$

\section{The Difference in Characteristic Marks}

The second theory that Vasubhandhu presented is the one ascribed to Ghoșaka, who intended to solve the problem of the reality of factors through time by assigning each factor three characteristic marks that account for the time in which the factor exists. The pertinent text passage reads as follows:

The venerable Ghoșaka claimed a difference in characteristic marks. He reportedly said: "A conditioned factor, when proceeding through the [three] times, is past when it is connected with the characteristic mark of the past without being separated from the characteristic marks of the future and the present. When it is future, it is connected with the characteristic mark of the future, without being separated from the characteristic marks of the past and the present. In the same way, also when it is present, [the factor] is not separated from the past and future. For example: A man who desires one woman is not indifferent to the remaining [women]."

\section{lakșaṇānyathiko bhadantaghoṣakah. sa kilāha: “dharmo 'dhvasu pravar- tamāno 'tīto 'tītolakșaṇayukto 'nāgatapratyutpannābhyām lakṣanāāhyām aviyuktaḥ. anāgato 'nāgatalakṣaṇayukto 'tītapratyutpannābhyām aviyuktaḥ. evam pratyutpanno 'py atītānāgatābhyām aviyuktah. tadyathā: puruṣa ekasyām striyām raktaḥ śeṣāsv aviraktaḥ” iti (AKBh 5.25; ed. Pradhan, p. 296, lines 16-19).}

According to Ghoșaka, conditioned factors possess three characteristic marks: that of the past, that of the presence, and that of the future. Two of the characteristics exist inactively, whereas the third one, while being active, determines the time in which the factors exist. The proceeding of a factor from one time to the next is due to a change in the activation of the characteristic marks. The characteristic mark that accords for the existence in one time becomes inactive, whereas the characteristic mark of the next time becomes active.

This brief account of Ghoșaka's theory does not explain which causes exactly lead to the activation of one of the three characteristic marks. However, the

\footnotetext{
38 "Dravya, too, is a complex, controversial, and elusive concept. ... Its meanings range from 'concrete individual' to 'bare substrate' and 'ultimate essence.'” Halbfass (1992, p. 90).

39 Chakravarti (1951, p. 26) understood Dharmatrāta's theory in this manner.

40 See below, section The Transformation of Properties and the Adaptation of Dharmatrāta's Theory.
} 
exemplification of his theory indicates that the Buddhist master may have thought of specific circumstances, just as the awareness of one specific attractive woman may lead to the activation of desire for this particular woman in a man, whose desire for other women remains latent and may be activated under different conditions. ${ }^{41}$

Vasubandhu, following the *Mahāvibhāṣāśāstra, rejected Ghoṣaka's theory, because he interpreted the existence of all three characteristic marks in a single entity as leading to the undesirable consequence of a mixture of the three times. ${ }^{42}$ According to this interpretation, Ghoșaka's theory implies that entities in all three times carry the potential of the other two times. Thus, a past entity would have the potential to become present or future again.

Patañjali, however, who was aware of the fact that Ghoșaka's theory was criticised with this argument, adaptively reused it as a second-level theory that explains the temporal transformation of properties (dharma). ${ }^{43}$

\section{The Difference in the State}

The third theory that Vasubandhu presented, i.e., the one attributed to the Buddhist master Vasumitra, became generally accepted in Sarvāstivāda Buddhism. Vasumitra regarded the state (avasthā) of a factor to be decisive for its temporal existence. In Vasubandhu's formulation, this theory reads as follows:

The venerable Vasumitra claimed a difference in the state. He reportedly said: "A conditioned factor when proceeding through the [three] times, having acquired this or that state, is designated as this or that, because of its different state, not because of its different substance. As a single stick, ${ }^{44}$ if put down at the place of one, is called 'one,' at the place of a hundred 'one hundred' and at the place of a thousand 'one thousand'."

avasthānyathiko bhadantavasumitra. sa kilāha: "dharmo 'dhvasu pravartamāno 'vasthām avasthām prāpyānyo 'nyo nirdiśyate, avasthāntarato na dravyāntaratah. yathaikā vartikaikāinke nikșiptaikam ity ucyate śatānke śatam sahasrānkke sahasram” iti (AKBh 5.25; ed. Pradhan, p. 296, lines 20-23).

\footnotetext{
41 This interpretation agrees with the one proposed by Chakravarti (1951, p. 96).

42 See Frauwallner (1973, p. 101) and Dessein (2007, p. 333).

43 See below, section The Transformation of the Characteristic Mark and Patañjali's Adaptation of Ghoșaka's Theory.

44 The meaning of the word vartikā is not entirely clear (cf. Wujastyk 2018, p. 41). Yaśomitra used the word gulikā "pellet" in his commentary on the Abhidharmakośa, which has a parallel in mrdgulika "clay pellet" in Kamalaśīla's Tattvasamgraha (p. 505, 1. 19). The Vibhāṣāprabhāvrtti uses the compound nikșepavarttikā, which might mean a "stick" (vartikā) used for placing on a particular position in order to work out mathematical calculations; Franklin Edgerton (1953, p. 294b, s.v. nikșepa) thought that nikșepa may refer to solving a mathematical problem, but Dominik Wujastyk informed me that such a usage of the word is not attested in works on Indian mathematics or astronomy (email communication on 25 May 2020).
} 
Vasumitra's theory explains the existence of a factor in the three times as a shift of the position of the factor in time, comparable to a single symbol in the decimal place value system that may have different values according to its position in the number range. ${ }^{45}$ This theory, according to Frauwallner, originally meant that the things move from one time interval to the next, even though the Sarvāstivāda did not have any conception of time as an independent entity. ${ }^{46}$ However, already in the early sources, the Sarvāstivāda exegetics interpreted Vasumitra's theory differently. ${ }^{47}$ They held the view that the state (avastha $)$ of a factor in time is determined by its activity (käritra). ${ }^{48}$ Factors with a present activity are said to exist in the present time, those with a past activity are past, and dharma-s with a future activity are future. According to Frauwallner, this new interpretation contradicts the originally intended theory and must be based on the confusion of two different Sarvāstivāda authorities who shared the same name. ${ }^{49}$

Irrespective of the original meaning of Vasumitra's theory, the notion that activity determines the time of a factor became not only widely accepted in Sarvāstivāda Buddhism, it also found its entrance in an adapted manner in the theory of the reality of the three times of the Pātañjalayogaśāstra, where Patañjali substituted the conception that activity determines the existence of a factor (dharma) in time with the concept of manifestation (vyakti) of a property (dharma) or a characteristic mark (lakșaṇa). ${ }^{50}$

\section{Relative Difference}

Vasubandhu ascribed the fourth Sarvāstivāda theory of temporality to the Buddhist master Buddhadeva, who thought that the relative difference of factors determines temporality. The Abhidharmakośabhāṣya reports this position as follows:

The venerable Buddhadeva claimed a relative difference. He reportedly said: "A conditioned factor, when proceeding through the [three] times, is designated as the one or the other with regard to what precedes and what

\footnotetext{
45 See Plofker (2009, p. 45f.).

46 "Die Lehre Vasumitras, welche mit einem Wandern der Dinge durch die Zeitstufen rechnet, ist, auch wenn sie keinen Zeitbegriff kennt, mit der Lehre der Dārșțāntikā und Vibhajyavādī aufs engst verwandt, .." (Frauwallner 1973, p. 105). Different authors may have referred with the terms "Dārștāntikas" and "Sautrāntikas" to the same group of philosophers who, while denying the real existence of factors throughout the three times (Cox 1995, pp. 38-40, referencing Katō 1989), maintained that only present factors exist. Despite their fundamentally different view on the ontological status of past and future factors, the Dārștāntikas alias Sautrāntikas agreed with Vasumitra's Vaibhāṣika theory in that the present state of a factor is characterised through its activity.

47 The interpretation of the state (avasthā) of factors consisting in their efficacy is already attested in the * Mahāvibhāṣāśāstra; see Dessein (2007, p. 333).

48 Chakravarti (1951, p. 96) understood avasthā as the "condition," under which a factor may or may not "produce its function."

49 Frauwallner (1973, p. 105).

50 See below, section The Transformation towards Actualisation of Properties through Characteristic Marks, and Patañjali's Adaptations of Vasumitra's and Buddhadeva's Theories.
} 
follows, because of its different states, not because of its different substance. Just as a single woman may either be called 'mother' or 'daughter'."

anyathānyathiko* bhadantabuddhadevah. sa kilāha: "dharmo 'dhvasu pravartamānaḥ pūrvāparam apekșyānyo 'nya ucyate, avasthāntarato na dravyāntaratah. yathaik $\bar{a}$ strī mātā vocyate duhitā vā" iti (AKBh 5.25; ed. Pradhan, p. 297, lines 1-3. Variant reading: anyathānyathiko] emendation (Isabelle Ratié); anyathānyathikī ed.).

Buddhadeva's theory explains the occurrence of factors in time through their relationship to other factors, just as a woman is called "daughter" in relation to her mother, and "mother" with regard to her child. In other words, a factor $a$ is past in relation to factor $b$ that originated subsequently to factor $a$. Likewise, factor $a$ is future in relation to factor $c$ that occurred before factor $a$ and so on. ${ }^{51}$

The theory of Buddhadeva met with criticism already in the earliest preserved vibhasșa compendium. ${ }^{52}$ There, and in later works, it was interpreted to lead to the undesired consequence that all three times exist in each of the three times, because of the sequential occurrence of factors with predecessors and successors. Accordingly, Buddhadeva's theory would lead to the inflation of the number of times beyond the well-established number three.

Patañjali nevertheless reused the exemplification of a single woman that may be referred to with different designations according to her relation to other persons to illustrate the theory of the transformation of the state (avastha) of the characteristic marks of properties. ${ }^{53}$

\section{Reasons for the Real Existence of Factors in the Three Times}

Already from the time of the earliest vibhāṣā compendia onwards, Sarvāstivāda Buddhism supported the reality of the existence of factors in all three times with four lines of argumentation. ${ }^{54}$ Vasubandhu mentioned these arguments in a nutshell in Abhidharmokośakārikā 5.25 and spellt them out in the subsequent bhāsya. ${ }^{55}$

The reality of all times [is established] (1) because [the Buddha] has declared it, (2) because [cognitions] arise from two, (3) because [cognitions have] real objects (4) and because [past factors have] results.

sarvakālāstitoktatvād dvayāt sadviṣayāt phalāt / (AKBh 5.24ab; ed. Pradhan, p. 295, lines 7-22).

This series of arguments draws first upon the Buddha's verbal testimony, which is considered trustworthy because the Buddha is assumed to be omniscient. The

\footnotetext{
51 See Sinha (1983, p. 129f.).

52 See Frauwallner (1973, p. 102).

53 See below, section The Transformation towards Actualisation of Properties through Characteristic Marks, and Patañjali's Adaptations of Vasumitra's and Buddhadeva's Theories.

54 See Lamotte (1988, p. 601f.).

55 See Williams (1981, p. 229f.).
} 
second argument is based on the Buddhist notion that consciousness depends on two sets of entities, namely (1) on the visual sense (cakșus) plus matter (rüpa) and (2) on the mind (manas) plus the factors (dharma). The third argument supports the real existence of factors in the times of the future and the past by drawing upon the idea that cognitions are based upon the existence of really existent entities. Thus, the fact that there are cognitions of past and future factors establishes the fact that past and future entities must exist in reality. The final argument draws upon the conception of karmic retribution, according to which the ethical value of actions determines the quality of experiences in the future. For producing fruition (phala) in the future, past actions need to have a real existence. ${ }^{56}$ As will be shown in the following section of this article, the final two arguments re-appear with only little adaptation in the Pātañjalyogaśāstra.

\section{The Reality of the Three Times in the Pātañjalayogaśāstra}

Patañjali addressed the problem of temporality in the context of his soteriology in PYŚ 4.12. There, he discussed the question of how mental impresses (vāsanā) that cause the continued existence of beings within the circle of rebirths by storing karma, may cease through yogic meditation as a means towards final liberation. ${ }^{57}$ The vanishing of the impresses is problematic from the perspective of Sānkhya, which denies the possibility of either the generation of an existing entity from nonexistence or of the decay of something existing. ${ }^{58}$ Pātañjali counters this possible objection against the Yogic soteriology by explaining that impresses do not lose their existence, but shift from one time to another:

The past and the future exist in reality because properties (dharma) belong to different times (Yogasütra 4.12). The future is what has a future manifestation, the past is what already had experienced manifestation, and the present is that of which its activity has [just] arrived. And one should know that this triad is the object (vastu) of knowledge. If these [three times] did not exist in reality, this knowledge, lacking an object, could not arise. Therefore the past and the present exist in reality. Moreover, if the fruition of karma, which necessarily arises as either leading to experiences [in the cycle of rebirths] or as leading to

\footnotetext{
56 See Willemen et al. (1998, p. 20).

57 The Sanskrit term vāsanā appears to have been adopted from Buddhist contexts into Pātañjala Yoga. Edgerton (1953, p. 478b, s.v.) provides the meanings "impression, result of past deeds and experiences on the personality" and refers his readers to the derivation of $v \bar{a} s a n \bar{a}$ from the verb vāsayati "perfumes." That Patañjali uses the term vāsanā as a quasi-synonym to saṃskāra "mental impression," is indicated in PYŚ 2.13 (ye samskārāh smrtihetavas tā vāsanās tāś cānādikālīnāh) and similar passages. Therefore it appears appropriate to follow Patañjali and render $v \bar{a} s a n \bar{a}$ with a quasi-synonym of "impression" into English, even if this translation neither conveys the etymology of the term nor distinctly Buddhist Yogācārāra connotations.

58 One of the cornerstones of classical Sānkhya philosophy is the theory of sarvasarvātmakavāda, i.e., the view that everything is contained in everything, which implies that no existing entity can be generated from non-being. The long history of this concept may be traced back to the teaching of Uddālaka Āruni in Chāndogya-Upaniṣad 6.1.2; cf. Bhagavadgītā 2.16ab: nāsato vidyate bhāvo nābhāvo vidyate satah /. See Wezler (1987, p. 179f.).
} 
liberation, would be unreal (nirupākhya), then abiding by what is wholesome, for which the instruction in this [fruition of karma] is the cause, would not be appropriate.

atītānāgatam svarūpato 'sty adhvabhedād dharmānām (YS 4.12). bhaviṣyadvyaktikam anāgatam, anubhūtavyaktikam atītam, svavyāpāropārūụham vartamānam. trayam caitad vastu jūānasya jñeyam. yadi caitat svarūpato nābhavișyat, nedam nirvișayam jñ̄annam udapatsyata. tasmād atītānāgatam svarūpato ștīti. kimca bhogabhāgīyasya vāpavargabhāgīyasya vā karmaṇạ̣ phalam utpitsu yadi nirupākhyam iti taduddeśena tena nimittena kuśalānuṣthānạ̣ na yujyeta. (PYŚ 4.12, ed. Āgāśe, p. 186, 1. 3-10).

Already Patañjali's usage of the technical term adhvan with reference to time in Yogasūtra 4.12 indicates a Buddhist influence upon the passage under discussion. ${ }^{59}$ The shared terminology is, however, not the only similarity of Patañjali's work with Sarvāstivāda Buddhism. Also, Patañjali's definition of the three times through references to manifestation (vyakti) and activity (vyāpāra) echoes the Sarvāstivāda interpretations of Vasumitra's theory, according to which the activity ( $k \bar{a} r i t r a$ ) of a factor determines its existence in the three times. ${ }^{60}$ In addition, Patañjali reused the two arguments for the real existence of the three times from Sarvāstivāda sources. His first argument in favour of the Yoga version of the Sarvāstivāda doctrine is quite similar to the second argument that Vasubandhu reported in his Abhidharmakośa: Past and future entities cause valid knowledge. To be valid, knowledge needs to be knowledge of a really existing entity. ${ }^{61}$ Patañjali's second argument, like the fourth argument of AKBh 5.25, draws upon the concept of karmic retribution. Past actions that lead to retribution in the present or future must be real because otherwise the allocation of the quality of experiences to the ethical quality of actions could not be upheld. Patañjali argues that if this were the case, religious teachings based upon the conception of karmic retribution would simply serve no purpose and, accordingly, would be meaningless. ${ }^{62}$

The apparent reuse of Sarvāstivāda conceptions on the reality of all three times raises questions concerning the deviating ontologies of Sarvāstivāda Buddhism and Yoga. As was explained above, ${ }^{63}$ according to Sarvāstivāda, the perceptible world consists of conditioned factors (dharma), each of which is present, i.e., active, for an

\footnotetext{
59 See Edgerton (1958, p. 18b), s.v. adhvan. The word adhvan is also recorded in Monier-Williams (1899, p. 23c, s.v.) with the meaning "time" for Buddhist and Jaina texts. A later attestation of adhvan meaning "time" than the one in Pātañjalayogaśāstra occurs in the Kālsamuddeśa of Bhartṛhari's Vākyapadīya 3.548c [Kālasamuddeśa 61] (see Rau 1988, p. 10 a, s.v.) which, according to the commentary of Helarāja, refers to the text of Pātañjalayogaśāstra 3.13, § 9 in Appendix (Vākyapadīya p. $63,1.27 \mathrm{ff}$.). Many thanks to Dominik Wujastyk for drawing my attention to Bhartrhari's usage of the word adhvan.

60 See above, section The Difference in the State.

61 See above, section Reasons for the Real Existence of Factors in the Three Times.

62 See Chakravarti (1951, p. 94f.).

63 See above, section Sarvāstivāda Buddhist Ontology and the Problem of Temporality.
} 
infinitesimal small time-span. ${ }^{64}$ For Sānkhya-Yoga, the perceptible world consists of the gross elements and the senses of living beings that are a transformation of primal matter (prakrti). Matter, which is unconscious, active, and subject to change, enters into transformation when it comes under the influence of a Subject (purusa). The transformation originates from matter when it is in an imperceptible and ungraspable state that is called "without characteristic mark" (alinga) and finally leads to everything existing in the perceptible world. The same process of transformation is responsible for every change in the outside world as well as for mental events. All these phenomena are, according to Pātañjala Yoga, nothing but transformations of the permanent but changeable matter which consists of the three basic constituents or forces (guna) sattva, rajas and tamas.

The ontology of Pātañjala Yoga thus differs fundamentally from the ontology of Sarvāstivāda Buddhism, which denies the existence of a permanent substrate. However, both ontologies agree that phenomena are momentary. For Sarvāstivāda, conditioned factors (dharma) are subject to momentariness, whereas in Pātañjala Yoga the properties (dharma) of a permanent substrate transform in every single moment. $^{65}$

\section{The Adaptive Reuse of Sarvāstivāda Theories of Temporality in the Pātañjalayogaśāstra}

Patañjali introduced his specific theory of transformation comprehensively in Pātañjalayogaśāstra 3.13, one of the longest bhāṣa-passages of the whole work. This theory comprises three different aspects: (1) the transformation of properties (dharma), (2) the transformation of characteristic marks (lakșana) of the properties that account for their passing through time and (3) the transformation of states (avastha $)$ of the properties and characteristic marks. ${ }^{66}$ All three kinds of transformation occur within this text passage in sequence twice. Initially, Patañjali explains each of them concerning the mental organ (citta) as the substrate of properties. Subsequently, he addresses the transformation of the entities of the outside world under the category of "elements and the senses" (bhütendriya).

\footnotetext{
64 The ontological inventory of Sarvāstivāda comprises not only the conditioned dharma-s, but also three uncondictioned factors (asamskrtadharma). See Schayer (1938, p. 19).

65 "Therefore the whole world experiences transforms within [each] single moment" tenaikena kṣaṇena krțtsno lokah parịnāmam anubhavati (PYŚ 3.52, ed. Āgāśe, p. 171, 1. 9).

66 "Of these [types of transformation], the transformation through properties refers to the substrate. The transformation through characteristic marks refers to the properties that exist in three times. And the transformation through states refers to the characteristic marks. In this way, the activity of the constituents [of matter] is not free from the transformations of properties, characteristic marks and states even for a second." (tatra dharmino dharmaị̣ parịnāmaḥ, dharmānā̄m tryadhvanām lakṣanaih parịnāmaḥ, lakṣaṇānām apy avasthābhịh parịnāma iti. evam dharmalakṣaṇāvasthāparịnāmaị śünyam na kṣaṇam api gunavrttam avatișthate. PYŚ $3.13, \S 4,1.1-5$ in Appendix.)
} 


\section{The Transformation of Properties and the Adaptation of Dharmatrāta's Theory}

In his initial treatment of the transformation of properties, which addresses the transformation of the mental organ in yogic meditation, Patañjali's explanations are quite succinct:

Of these [transformations], the transformation of properties [present] in a substrate is the disappearance and appearance of the properties of activation and cessation. ${ }^{67}$

tatra vyutthānanirodhayor dharmayor abhibhavaprādurbhāvau dharmiṇi dharmapariṇāmah (PYŚ 3.13, § 2 in Appendix).

Within the second exposition of the transformation of properties, Patañjali explains the transformation of a property (dharma) in time as the transformation of the mode of its being (bhāva).

In this case, the property (dharma) changes its mode of being, not its substrate (dravya), when it passes in a substrate through the three times of past, future, and present. For example: A vessel made of gold that is destroyed and made into something different changes its mode of being, not its being gold.

tatra dharmasya dharmiṇi vartamānasyādhvasv atītānāgatavartamāneșu bhāvānyathātvam bhavati, na dravyānyathātvam. yathā suvarṇabhājanasya bhittvānyathākriyamānasya bhāvānyathātvam bhavati na suvarṇānyathātvam iti (PYŚ 3.13, § 6, 1. 1-3 in Appendix).

In this passage, Patañjali adaptively reused the wording of $\mathrm{AKBh} 5.25$ or a very similar formulation, which reports Dharmatrāta's Sarvāstivāda theory of temporality, by changing the wording of his exemplar slightly. ${ }^{68}$ First, Patañjali added the word dharmini "in a substrate" to render Dharmatrāta's theory consistent with his ontological premise of the existence of a permanent but changing entity, i.e., primordial matter (prakrti), the transformation of which accounts for all entities of the world, except the Subjects (puruṣa). Adding a single word, Patañjali also achieved a far-reaching semantic shift for the word dharma within the reused passage. The word is deprived of its Sarvāstivāda Buddhist meaning "conditioned factor," or "element of existence" and assumes the meaning "property" or "quality" of a substrate. In its adapted and Sānkhya-specific meaning, the word does not designate, as it did in its original context, an individual ontological unit or constituent of the world. It now designates a property with a minimal existence of its own, which intrinsically belongs to its underlying substrate. Patañjali introduced a similar semantic shift also with regard to the word dravya within the compound

\footnotetext{
67 The term "activation" (vyutthāna), which Patañjali used to refer to all forms of the functioning of the mental organ (cittavrtti), is the antonym of "cessation" (nirodha).

${ }^{68}$ For a detailed comparison of the wording of the two passages from AKBh 5.25 and PYŚ 3.13, see Table 1, below.
} 
Table 1 The wording of Dharmatrāta's theory according to AKBh 5.25 in comparison to PYŚ 3.13

Abhidharmakośabhāṣya 5.25 (ed. Pradhan) Pātañjalayogaśāstra 3.13, § 6, 1. 1-3

dharmasya_adhvasu pravartamānasya

bhāva-anyathātvam bhavati

na dravya-anyathātvam. yathā suvarna-

bhājanasya bhittvā_anyathā kriyamāṇasya

saṃsthāna-anyathātvam bhavati na varna-

anyathātvam

\author{
dharmasya dharmiṇi vartamānasya_adhvasv \\ atîtānāgatavartamāneșu bhāva-anyathātvam bhavati \\ na dravya-anyathātvam. yathā suvarna- \\ bhājanasya bhittvā_anyathā-kriyamānasya \\ bhāva-anyathātvam bhavati na suvarna- \\ anyathātvam iti
}

In Table 1 and all other tables of the present article, insignificant textual deviations are set in Roman characters, whereas deviations involving a significant difference of meaning are set in Roman and bold characters. To facilitate the comparison of the two passages, external and internal vocalic sandhi is resolved and word stems in compounds joined with hyphens. Resolved external sandhi is indicated by underline

dravyānyathātvam, which in his adaptation now refers to a permanent substrate rather than to a momentary individual entity. ${ }^{69}$

A further change, less significant for the new Sānkhya-specific meaning but indicative of the direction of adaptation, is the introduction of the compound atītānāgatavartamāneșu "in the past, future and present" as an explanatory gloss of the word adhvasu "in the times." Patañjali felt the need to explain the term adhvan "time" which he may have thought to be unfamiliar for those of his readers who lacked acquaintance with the terminology of Sarvāstivāda Buddhism as referring to the past, present and future time.

Additional adaptations in the wording of Dharmatrāta's Sarvāsitvāda theory occur in the exemplification. Here Patañjali changed Dharmatrāta's "shape" (samsthāna) to bhāva "mode of being" and Dharmatrāta's varna- "colour" to suvarna- "gold". These changes are again probably motivated by Patañjali's intention to get rid of specifically Buddhist terminology and to create a description of the Sānkhya-Yoga theory of transformation of a permanent substrate. In Patañjali's exemplification, the decisive aspect that the vessel maintains while changing its mode of being is not any longer its specific colour (varna), but its being a permanent substrate, i.e., gold (suvarna) ${ }^{70}$ By employing a small modification of wording, i.e., by adding the prefix $s u$ - to the word varna, Patañjali transformed the word "colour" into "gold."

Patañjali anticipated criticism of his theory of transformation from the camp of philosophers_-possibly Buddhists-who were not willing to accept the existence of a continuous substrate as the carrier of properties: ${ }^{71}$

\footnotetext{
69 See above, section The Difference in the Mode of Being.

70 As mentioned above (section The Difference in the Mode of Being), already Patañjali the grammarian referred to different items made of gold as exemplifications for the relationship of shape (ākrti) to substance (dravya) around the year 150 BCE.

71 The Pātañjalayogaśāstra does not identify the opponent with any particular philosophical school of thought. The Pātañjalayogaśāstravivaraṇa just refers to the opponent as someone who denies the production of the result from its previously existent cause (asatkāryārambhäbhimānin p, 146, 1. 20),
} 
An opponent argues: "The substrate is nothing more than a property because it cannot go beyond [being] the previous entity. When it is subject to the different states of being previous or later, it would have to be unchangeable if it would be continuous (anvayin)."

apara āha: "dharmānabhyadhiko dharmī pūrvatattvānatikramāt. pūrvāpar$\bar{a}$ vasthābhedam anupatitah kauțasthyenaiva parivarteta yady anvaȳ syāt" iti (PYŚ 3.13. § 6, 1. 3-5 in Appendix).

This argument criticises the ontology of Sānkhya, which is based on the premise of the continuous existence of a substrate, by taking it ad absurdum. If a substrate can be identified as an entity, like a lump of clay, it cannot be claimed to remain identical through time, because everyday experience shows that entities change, as, for example, a lump of clay may turn into a pot. If the Sānkhyin tries to avoid this difficulty by claiming that the alleged entity is just a property of a continuously existent substrate, then he would have to concede to the undesirable consequence that the substrate is unchangeable. This, however, would violate the Sānkhya teaching of primal matter as being permanent but changeable.

To counter this argument, Patañjali points out that his ontology is based on premises that differ from those underlying the objection.

Our position is not wrong. Why? Because we do not accept a one-sided position: This whole world here loses its manifestation, because we deny its permanence. Even when it has lost [its manifestation], it still exists, because we deny its destruction. Its subtlety arises from merging [into causes], ${ }^{72}$ and because of its subtlety, it cannot be perceived.

ayam adoṣah. kasmāt? ekāntatānabhyupagamāt: tad etat trailokyam vyakter apaiti nityatvapratiședhāt. apetam apy asti vināśapratiședhāt. samsargāc cāsya saukșmyam, saukșmyāc cānupalabdhir iti (PYŚ 3.13, § 6, 1. 5-7 in Appendix).

This passage, which the author of the Yuktidipika ascribes in his commentary on Sānkhyakārika 10 to the followers of Vārșaganya, ${ }^{73}$ whereas Patañjali does not mark it as a quotation, is based on an ontology that has no room for the dichotomy of being and non-being. ${ }^{74}$ The things of the world are manifestations of the potential

\footnotetext{
Footnote 71 continued

which characterises all philosophers outside the Sānkhya school of thought. Vācaspatimiśra introduced his commentary on this objection by naming the opponent a bauddha (see Tattvavaiśāradī on PYŚ 3.13, p. 127, 1. 15).

72 "Merging" (samsarga) is a specific Sānkha-related term that is not well-attested in modern Sanskrit dictionaries. It is "used here to denote the rejoining of a phenomenon with its cause(s) after having been manifest for some time, whereas the opposite process is called visarga" (Wezler 1987, p. 177); cf. Halbfass (1992, p. 59), who rendered samsarga as "merger."

73 Yuktidīpikā 10, ed. Wezler and Motegi (1998, p. 128, 1. 23).

74 Vātsyāyana quoted this passage in his Nyāyabhāṣya to provide an example for the self-contradictory (viruddha) fallacious reason (hetvābhāsa). See Nyāyabhāṣya 1.2.6, p. 43f.
} 
contained in a changeable but permanent substance. When entities seem to vanish, they just lose their manifestation. This loss is, however, not a loss of existence, but a merging into an underlying cause, which leads to subtlety, or in other words, to a loss of properties resulting in imperceptibility and not in inexistence.

\section{The Transformation of the Characteristic Mark and Patañjali's Adaptation of Ghoșaka's Theory}

The treatment of the transformation of characteristic marks (lakșana) concerning the mental organ (citta) is much more comprehensive than the explanation of the transformation of properties discussed above. This very fact may already indicate that Patañjali introduced this theory as an innovation to Sānkhya philosophy, which was necessary for explaining how properties of the mental organ change in a way that accounts for the very possibility of spiritual liberation without violating the Sānkhya premise that whatever exists cannot cease. ${ }^{75}$ The passage under consideration reads as follows:

The transformation of characteristic marks: Cessation [of mental activity] has three characteristic marks, [that is to say] it is connected with the three times. When this [cessation] gives up the time with the characteristic mark of the future without desisting from being a property, it attains the characteristic mark of the present, in which it manifests in its own form. This is its second time. And this [cessation] is not disconnected from the characteristic marks of the past and the future. In the same way, activation has three characteristic marks, [that is to say] it is connected with the three times. When this [activation] gives up [the time with] the characteristic mark of the present without desisting from being a property, it attains the characteristic mark of the past. This is its third time. And this [activation] is not disconnected from the characteristic marks of the future and the present. While arising, reactivation gives up [the time with] the characteristic mark of the future without desisting from being a property. It attains the characteristic mark of the present, in which, when it manifests in its own form, it is active. This is its second time. And this [re-activation] is not disconnected from the characteristic marks of the past and the future. In the same way cessation [occurs] again and activation [occurs] again.

lakșaṇaparịnāmaḥ: nirodhas trilakșaṇah, tribhir adhvabhir yuktaḥ. sa khalv anāgatalakșaṇam adhvānam hitvā dharmatvam anatikrānto vartamānam lakṣaṇam pratipannah̆, yatrāsya svarūpeñābhivyaktih. eșo 'sya dvitīyo 'dhvā na cātītānāgatābhyām lakṣaṇābhyām viyuktah. tathā vyutthānam trilakṣanam, tribhir adhvabhir yuktam, vartamānalakșaṇam hitvā dharmatvam anatikrāntam atītalakșaṇaṃ pratipannam. eșo sya tritīyo 'dhvā na cānāgatavartamānābhyām lakșaṇābhyām viyuktam. punar vyutthānam

\footnotetext{
75 See above, n. 59.
} 
upasampadyamānam anāgatalakșaṇam hitvā dharmatvam anatikrāntam vartamānalakṣaṇam pratipannam, yatrāsya svarūpābhivyaktau satyām vyāpāraḥ. eșo 'sya dvitīyo 'dhvā. na cātītānāgatābhyām lakșaṇābhyām viyuktam iti. evam punar nirodha evam punar vyutthānam iti (PYŚ 3.13, § 3, in Appendix).

As discussed above, Patañjali regarded the different states of the mental organ that may appear and vanish sequentially during yogic practices, i.e., the cessation of mental activity (nirodha) and activation (vyutthāna), as properties (dharma) of a continuously existing substance (dharmin). The change that these properties undergo in their temporal dimension is neither a generation of something new nor the destruction of something already existent. Properties, just like their substrate, exist continuously. They change, however, their characteristic marks, which accounts for their specific being in one of the three times.

In creating his specific theory of transformation, Patañjali adaptively reused the second theory reported in Vasubandhu's Abhidharmakoṣabhāṣa, i.e., the theory ascribed to Ghoșaka, which explains temporal change through the three characteristic marks that exist in all three times. ${ }^{76}$ The adaptation of Ghoșaka's theory reads as follows:

The transformation of characteristic marks: A property that exists in the three times is past when it is connected with the characteristic mark of the past without being separated from the characteristic marks of the future and the present. In the same way, it is future when it is connected with the characteristic mark of the future without being separated from the characteristic marks of the present and the past. In the same way, it is present when it is connected with the characteristic mark of the present without being separated from the past and the future. Just as a man, who desires one woman, is not detached from the remaining [women].

lakșaṇaparin̄āmaḥ: dharmo 'dhvasu vartamāno 'tīto 'tītalakșaṇayukto 'nāgatavartamānābhyām lakșaṇābhyām aviyuktah. tathānāgato 'nāgatalakșaṇayukto vartamānātītābhyām lakșaṇābhyām aviyuktaḥ. tathā vartamāno vartamānalakșaṇayukto 'tītānāgatābhyām aviyukta iti. yathā puruṣa ekasyām striyām rakto na śeșāsu virakto bhavatīti (PYŚ 3.13, § 7 in Appendix).

Ghoșaka's theory originally was an alternative to the one by Dharmatrāta, which explained temporality as a change of the mode of being (bhāva) in conditioned factors (dharma). In Patañjali's reused version, Ghoșaka's theory turned into a second-level theory to the theory of transformation of properties (dharma), which accounts for their temporality by assigning to properties three characteristic marks. Since Patañjali's adaptation of Dharmatrāta's theory had already involved a semantic shift in the meaning of the word dharma from the Buddhist meaning

$\overline{76}$ See above, section The Difference in Characteristic Marks. 
Table 2 The wording of Ghoșaka's theory according to AKBh 5.25 in comparison to PYŚ 3.13

\begin{tabular}{|c|c|}
\hline Abhidharmakośabhāṣya 5.25 (ed. Pradhan) & $\begin{array}{l}\text { Pātañjalayogaśāstra } 3.13 \\
\text { ( } § 7 \text { in Appendix })\end{array}$ \\
\hline $\begin{array}{l}\text { dharmo 'dhvasu pravartamāno 'tīto 'tīta-lakșana-yukto } \\
\text { 'nāgata-pratyutpannābhyām lakṣanāahyām } \\
\text { aviyuktah }\end{array}$ & $\begin{array}{l}\text { dharmo 'dhvasu vartamāno } \\
\text { 'tito 'tīta-lakșaṇa-yukto 'nāgata- } \\
\text { vartamānābhyām lakṣaṇābhyām aviyuktah }\end{array}$ \\
\hline $\begin{array}{l}\text { anāgato 'nāgata-lakșana-yukto } \\
\text { 'tīta-pratyutpannāahyām aviyuktah }\end{array}$ & $\begin{array}{l}\text { tathā_anāgato 'nāgata-lakșaṇa-yukto } \\
\text { vartamāna-atītābhyām lakṣaṇābhyām } \\
\text { aviyuktaḥ }\end{array}$ \\
\hline $\begin{array}{l}\text { evaṃ pratyutpanno 'py atīta-anāgatābhyām } \\
\text { aviyukta iti }\end{array}$ & $\begin{array}{l}\text { tathā vartamāno vartamānalakṣanayukto } \\
\text { 'tītānāgatābhyām aviyukta iti }\end{array}$ \\
\hline $\begin{array}{l}\text { tad-yathā: puruṣa ekasyām striyām raktah śeșāsv } \\
\text { avirakta iti }\end{array}$ & $\begin{array}{l}\text { yathā: purușa ekasyām striyām rakto na } \\
\text { śeșāsu virakto bhavati_iti }\end{array}$ \\
\hline
\end{tabular}

"conditioned factor" to the Sānkhya-related "property," Patañjali could implement Ghoșaka's theory in his theory without significant textual changes. ${ }^{77}$

As mentioned above, Ghoșaka's theory was criticised within the circles of Sārvāstivāda Buddhism because it was taken to imply a mixture of times. ${ }^{78}$ The same criticism is also voiced and refuted within Patañjali's exposition of the theory:

Others object that in this [theory of] transformation of characteristic marks the times would be mixed because all [properties] are connected with all [three] characteristic marks. The refutation of this [objection runs as follows]: The fact that properties are properties is uncontroversial. And if the state of being a property exists, different characteristic marks need to be acknowledged, [since] the present time is not the only characteristic mark of this property. Because, if it were like this, the mental organ with the property of craving would not exist at the time of aversion, since it does not execute craving.

“atra lakșanaparināme sarvasya sarvalakṣanayogād adhvasamkarah prāpnoti" iti parair doṣaś codyate. tasya parihārah: dharmānām dharmatvam aprasādhyam. sati ca dharmatve lakșanabhedo 'pi vācyah, na vartamānasamaya evāsya dharmasyaikalakșaṇam. evam hi na cittam rāgadharmakam syāt krodhakāle rāgasyāsamudācārāt, iti (PYŚ 3.13, § 8, 1. 1-4 in Appendix).

According to Patañjali, the second-level theory of characteristic marks follows necessarily from the reality of properties of substrates, because properties change over time. If the temporality of the properties would be denied, the reality of the substrate could not be maintained. The substrate would stop to exist as soon as its properties change.

\footnotetext{
77 See Table 2, below.

78 See above, section The Difference in Characteristic Marks.
} 


\section{The Transformation Towards Actualisation of Properties Through Characteristic Marks, and Patañjali's Adaptations of Vasumitra's and Buddhadeva's Theories}

Patañjali introduced his theory of the transformation of state (avasthā) by applying it to the mental organ and its states during yogic meditations and normal functioning:

Likewise, the transformation of state [is the following one]: At the moments of cessation, the impressions of cessation are strong, and the impressions of activation are weak. This is the transformation of the state of properties.

tathāvasthāparināmah: nirodhakșaneșu nirodhasamskārā balavanto bhavanti, durbalā vyutthānasaṃskārā iti. eșa dharmāṇām avasthāpariṇāmaḥ (PYŚ 3.13, $\S 4,1$. 1f. in Appendix).

This brief explanation indicates that Patañjali's theory of the transformation of the state of properties deals with properties during their existence in the present time. Similar to Vasumitra's theory of temporality, which explains the difference of times through a change of the state of factors within the temporal space that coincided with a change in efficacy (kāritra), Patañjali's theory involves efficacy, which in the present example is the efficacy to produce impressions in the mental organ that can be reactivated as memories at a later instance.

Patañjali's indebtedness to Vasumitra and Buddhadeva reveals itself even more clearly in his application of this theory to the entities of the outside world:

It is not the substrate that exists in the three times, but the properties exist in the three times. And they either have a [specific] characteristic mark, or they do not have it. Of these, the [properties] with a [specific] characteristic mark, when they obtain this or that state, are designated differently, because of their difference in state, not because of their difference in substance. Just like a single line is a hundred at the position of a hundred, ten at the position of ten and one at the position of one. Or just like a woman, although she is a single person, is called a mother, a daughter, or a sister.

na dharmī tryadhvā, dharmās tryadhvānah. te lakṣitā alakṣitāḥ. tatra lakșitās tām tām avasthām prāpnuvanto 'nyatvena pratinirdiśyante, avasthāntarato na dravyāntaratah. yathaikā rekhā śatasthāne śatam, daśasthāne daśa, ekā caikasthāne. yathā vaikatve 'pi strī "mātā" cocyate "duhitā" ca "svasā" ceti (PYŚ $3.13 \S 9$ in Appendix).

Already the almost identical formulation of the two exemplifications and the usage of the identical term avasth $\bar{a}$ indicate that the theories of Vasumitra and Buddhadeva as they were formulated in Vasubandhu's Abhidharmakośabhāsya may have inspired Patañjali's formulation of this theory, even if the degree of literary 
agreement in this adaptation is lower than the one of the two previously discussed cases. $^{79}$

The two Buddhist theories of Vasumitra and Buddhadeva explained temporality with reference to the state (avasthā) of conditioned factors. For Vasumitra, temporality was the result of the movement of a factor within the temporal space, from one state to the next, which he compared to a single symbol or item in the mathematical decimal place value system that assumes different values according to its position. The different values of the stick or pellet illustrate for Vasumitra the travel of a single property through the time of its existence from one time to another. This theory was interpreted as a change in the efficacy of factors. ${ }^{80}$ For Buddhadeva, however, the change of the state did not occur in a temporal space, but in relation to other factors. Accordingly, the mutual relationship of factors defines their temporality. Patañjali integrated both Buddhist theories into his Sānkhya theory of the transformation of states (avasthā) in the present time. Just like a single line executes different efficacies within the number range, properties can be actualized through their characteristic marks as entities in the present time. In Patañjali's exemplification, a single vertical line can actualize the value of one, ten or a hundred, dependent on the number of numerals attached to it. ${ }^{81}$ Patañali also acknowledged that the efficacy of a property is relative to the actualisation of other properties, just like the relational terms "mother," "daughter," and "sister" are used concerning the relationship of two persons.

\section{Conclusion}

Towards the end of this comprehensive exposition of the transformation of matter, Patañjali provided an exemplification of his theory of transformation of properties (dharma) including the second-level theory of the transformation of characteristic marks (laksana) and the third-level theory of states (avasthā):

For this [theory] there is an exemplification: The substrate clay, when it assumes a property that differs from the property of having the shape of a lump, transforms into the shape of a pot regarding its property. The shape of the pot gives up the future characteristic mark and attains the present characteristic mark [and] thus transforms concerning its characteristic mark. The pot, which experiences being [relatively] new and old at every moment, attains the transformation of its state. For the substrate, its state is [the attainment of] a different property, and for the property, its state is [the attainment of] a different characteristic mark. Thus one single transformation

\footnotetext{
79 See below, Table 3.

${ }^{80}$ See above, section The Difference in the State.

81 In Patañjali's adaptation, the example involves the concept of the decimal place value system in writing, in which a vertical line or stroke fulfils a function similar to that of the stick or pellet in the original example. Quite interestingly, in Patañjali's version, the single line substitutes in descending order the hundred, the ten, and the one, whereas in the original example the stick substitutes the one, the hundred and the thousand in ascending order, leaving out the ten.
} 
Table 3 The wording of the theories of Vasumitra and Buddhadeva according to AKBh 5.25 in comparison to PYŚ 3.13

\begin{tabular}{|c|c|}
\hline Abhidharmakośabhāṣya 5.25 (ed. Pradhan) & Pātañjalayogaśāstra $3.13, \S 9$ in Appendix \\
\hline $\begin{array}{l}\text { dharmo 'dhvasu pravartmāno 'vasthām avasthām } \\
\text { prāpyānyo 'nyo nirdiśyate 'vasthāntarato na } \\
\text { dravyāntaratah }\end{array}$ & $\begin{array}{l}\text { na dharmī tryadhvā dharmās tryadhvānaḥ. te lakṣitā } \\
\text { alakșitāḥ. tatra lakșitās tāṃ tām avasthām } \\
\text { prāpnuvanto 'nyatvena pratinirdiśyante } \\
\text { 'vasthāntarato na dravyāntaratah }\end{array}$ \\
\hline $\begin{array}{l}\text { yathā_ekā vārtikā eka-anke nikșiptā ekam ity } \\
\text { ucyate śata-anjke śatam sahasra-añke sahasram iti }\end{array}$ & $\begin{array}{l}\text { yathā_ekā rekhā śata-sthāne śatam daśa-sthāne } \\
\text { daśa_ekā ca_eka-sthāne }\end{array}$ \\
\hline $\begin{array}{l}\text {.. “'dharmo 'dhvasu pravartamānah pūrvāparam } \\
\text { apekșyānyo 'nya ucyate, avasthāntarato na } \\
\text { dravyāntaratah }\end{array}$ & \\
\hline yathā_ekā strī mātā vā_ucyate duhitā vā"” iti & $\begin{array}{l}\text { yathā vā_ekatve 'pi strī mātā ca_ucyate duhitā ca } \\
\text { svasā ca_iti }\end{array}$ \\
\hline
\end{tabular}

is explained as having parts. In the same way, [this theory] also applies to [all] other entities.

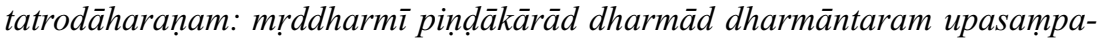
dyamāno dharmatah parinamate ghațākāra iti. ghațākāro 'nāgatam lakșanam hitvā vartamānam lakṣanam pratipadyata iti lakṣaṇatah parịnamate. ghato navapurānatām pratikṣaṇam anubhavann avasthāparin̄āmam pratipadyata iti. dharmino 'pi dharmāntaram avasthā, dharmasyāpi lakṣaṇāntaram avasthā, ity eka eva parināmo bhedenopadarśita iti. evam padārthāntareșv api yojyam iti (PYŚ 3.13, § 12 in Appendix).

Patañjali exemplified his Sānkhya-derived ontology through the substrate clay, whose modification into different shapes he employed to illustrate the transformation of primal matter into all entities of the perceptible world. According to Patañjali's analysis, a pot, just like all other things in the world, does not exist as an individual entity; it is a property of its substrate, just like the things in the world are properties of the substrate matter (pradhāna). Properties, i.e., alleged entities, appear when they actualise their inherent time characteristics of the present, and they disappear, when they actualise their time characteristic of the past. The actualisation of a different property in a substrate which goes along with the actualisation of a different time characteristic of a property is the transformation of the state (avastha) of the substrate.

The validity of Patañjali's theory of transformation as involving three different interrelated aspects is, however, only limited to a conventional level of truths. Ultimately, transformation is nothing but the transformation of the substrate.

From this [exposition], one should understand that concerning the elements and the senses transformation is threefold because properties and their substrate differ. According to the ultimate truth, however, there is just one transformation because a property is nothing more than the nature of its 
substrate, and this modification of the substrate is proliferated by [a reference to] properties.

etena bhütendriyeșu dharmadharmibhedāt trividhah parị̣āmo veditavyaḥ. paramārthatas tv eka eva parịnāmaḥ, dharmisvarūpamātro hi dharmaḥ, dharmivikriyaivaișā dharmadvārā prapañcyata iti (PYŚ 3.1.3, $\S 5$ in Appendix).

Although the triple theory of transformation is generally valid and can be defended against objections, it represents only a limited or conventional perspective on the reality of transformation. On a higher level of truth (paramärthatah) transformation is not a triple but a single unitary process. It is the mutually incompatible activity of the qualities or forces (guna) which make up primal matter (prakrti). Patañjali restated this crucial point in concluding his exposition of the theory of a triple transformation:

These very transformations of properties, characteristic marks and states do not transgress the nature of the substrate, so that only a single transformation accounts for all these [three] specific aspects: Transformation is the arising of a different property when the previous property of a continuous substrate passes away.

ta ete dharmalakṣaṇāvasthāparị̣āmā dharmisvarūpam anatikrāntā ity eka eva parịnāmah sarvān amūn viśeșān abhiplavate: avasthitasya dravyasya pūrvadharmanivrttau dharmāntarotpattị̆ parịnāma iti (PYŚ 3.13, § 13 in Appendix).

The previous pages have shown that Patañjali adaptively reused the wording of the original Buddhist Sarvāstivāda theories with slight modifications to formulate a new sānkhya-theory in such a way that the four Sarvāstivāda theories remained recognizable. His close adherence to the wording of his exemplars does not indicate a lack of creativity or philosophical ingenuity. It expresses a strategy designed to win the argument against the adherents of Sarvāstivāda Buddhism by demonstrating that their own, in Patañjali's view defective, theories of temporality can be rendered acceptable through slight modifications of wording, which involve a major ontological reorientation towards Sānkhya. The validity of this novel theory is, however, only provisional. On a higher level of reality, there is only a single transformation, which may be described elegantly and simply as the arising of a new property when a previous property vanishes.

This formulation is quite similar to, though not identical with, the characterisation of transformation in other sources. According to the Abhidharmakośabhāsya "transformation is the appearance of one property on a permanent substrate when another property vanishes". ${ }^{2}$ In Vasubandhu's formulation, properties become apparent (prādurbhāva), whereas for Patañjali, they arise (utpatti). Patañjali's

\footnotetext{
82 avasthitasya dravyasya dharmāntaranivịttau dharmāntaraprādurbhāva iti. AKBh 3.50, ed. Pradhan, p.159, 1. 19f.
} 
concluding formulation of his theory of transformation is also quite close to the metrical characterisation of transformation quoted in the Yuktidipika , which states that "transformation is called [the process concerning] a substrate that is not deprived of existence when it gets rid of one previous property and assumes a later one". 83

It thus appears that Patañjali concluded his novel theory of transformation with a formulation that is very much in line with the views of previous and contemporary mainstream Sānkhya philosophers. The innovative aspect of Patañjali's theory is therefore not to be found in its conclusion, but in its derivation as a process that on a conventional level can be analysed as being triple.

Patañjali's elegant and catchy conclusion of his argumentation was, however, at risk of being truncated in the course of its reception, since his formulation involved the concepts of arising (utpatti) and passing away (nivrtti). This reference to generation could be interpreted as a violation of the Sānkhya tenet of sarvasarvātmakavāda, according to which the destruction of something previously existent and the generation of something previously inexistent are equally impossible. As already Wilhelm Halbfass noticed, an objection along this line of argumentation, which could only be raised if Patañjali's formulation was taken out of its original context, appears indeed in the Yuktidīpikā on Sāikhyakārikā 9, where an opponent quotes Patañjali's formulation of transformation as involving the notion of the generation of something previously inexistent and the destruction of something existent. ${ }^{84}$

For what is called "transformation" is the passing away of one property and the arising of another property of a continuous substrate. This theory does not provide an alternative way [of defending the notion that the effect pre-exists in its cause], because in this [theory] the cessation of one property is accepted and the arising of something inexistent (i.e., of the new property) is asserted.

parin̄āmo* hi nāmāvasthitasya dravyasya dharmāntaranivrttir dharmāntarapravrttiś ca. tatra sato dharmāntarasya nirodhābhyupagamād asataś cotpattipratijñanān nedạ̣ mārgāntaram ārabhyate (Yuktidīpikā on Sānkhyakārikā 9, ed. Wezler and Motegi 1998, p. 111, 1. 15 f. Variant: * parināmo] correction of parimāṇo).

After a comparatively long discussion of various objections against the notion that the effect pre-exists in the cause, the author of the Yuktidipika refuted the objection that the theory of transformation involves the notion that entities may be generated or destroyed. He arrived at the conclusion that during transformation

\footnotetext{
83 jahad dharmantaram pūrvam upādatte yadā param / tattvād apracyuto dharmī parịnāmaḥ sa ucyate // (ed. Wezler and Motegi 1998, p. 111, 1. 21f.). The relative chronology of this anonymous quotation to the Pātañjalayogaśāstra is unclear.

84 See Halbfass (1992, p. 200f., n. 71) and Bronkhorst (1994, p. 318).
} 
properties are neither generated nor destroyed. They just appear and disappear, which affects their epistemological rather than their ontological status. ${ }^{85}$

On the whole, however, Patañjali was successful in formulating a theory of transformation that was well received as magisterial in circles of Sānkhya philosophy, since it is precisely this formulation that Vātsyāyana quoted in Nyāyabhāsya 3.2.15 as one out of two similar formulations of virtually the same theory of transformation that he intended to refute because it was incompatible with his Nyāya-specific ontology. ${ }^{86}$

Funding Open Access funding enabled and organized by Projekt DEAL.

\section{Compliance with Ethical Standards}

Conflict of interest The author states that there is no conflict of interest.

Open Access This article is licensed under a Creative Commons Attribution 4.0 International License, which permits use, sharing, adaptation, distribution and reproduction in any medium or format, as long as you give appropriate credit to the original author(s) and the source, provide a link to the Creative Commons licence, and indicate if changes were made. The images or other third party material in this article are included in the article's Creative Commons licence, unless indicated otherwise in a credit line to the material. If material is not included in the article's Creative Commons licence and your intended use is not permitted by statutory regulation or exceeds the permitted use, you will need to obtain permission directly from the copyright holder. To view a copy of this licence, visit http:// creativecommons.org/licenses/by/4.0/.

\section{Appendix: Pātañjalayogaśāstra 3.13 Critically Edited}

For the convenience of the reader, the text passages critically edited below are divided into paragraphs that neither occur in the printed editions nor the manuscripts of Patañjali's work. ${ }^{87}$

In the critically edited text, wavy underlines indicate that the reconstruction of the archetype is uncertain and that at least one viable alternative exists among the recorded variants.

\footnotetext{
$85 \ldots$ transformation is the appearance of one property and the disappearance of the previous property of a substrate. And appearance and disappearance are not [the same as] generation and destruction ... dharmino dharmātarasyāvirbhāvah pūrvasya ca tirobhāvah parināmah. na cāvirbhāvatirobhāvāv utpattinirodhau (Yuktidīpikā on Sānkkhyakārikā 9, ed. Wezler and Motegi 1998, p. 121, 1. 5f.).

86 'OOne [objector] says 'a transformation of milk [occurs]' and [thinks] that transformation is the arising of a new property of a continuous substrate when the previous property ceases. Another [objector] claims: 'It is the appearance of another quality', and [thinks] that another quality arises when the previous quality of an existing substrate ceases. This is almost the assertion of the same position." "payasah parināmah" eka āha - parin̄āmaś cāvasthitasya dravyasya pūrvadharmanivrttau dharmāntarotpattir iti. "gunāntaraprādurbhāvah" ity apara āha - sa ca sato dravyasya pūrvagunanivrttau guñāntaram utpadyata iti. sa khalv ekapakșībhāva ivāyam (Nyāyabhāṣya 3.2.15, p. 183, 1. 1-3).

87 The conventions applied in the critical edition below are identical with the conventions applied in Maas 2018 b (87 f.), from which I quote the following introduction almost verbatim.
} 
The word forms resulting from the application of the euphonic rules (sandhi) have been standardised in the critically edited text, regardless of which word forms occur in the manuscripts. Moreover, punctuation marks have been introduced that are based on the interpretation of the text; the actual punctuation marks in the manuscripts were not taken into consideration.

The critical apparatuses are arranged according to lemmata extracted from the critically edited text for recording variant readings. If identical words or word stems occur within a single line of text, the lemmata are marked by superscript numbers according to their position within the line. The variants are recorded for all witnesses in the following way: First, the sigla of witnesses supporting the reading of the critically edited text are listed. Then, separated by a semicolon, the first variant reading is recorded. This is followed by a list of sigla of witnesses that read this variant, etc. Sometimes the reading of a particular witness is not available due to a longer lacuna in the text, or because the reconstruction of the reference text commented upon in a commentary is impossible due to a lack of reference to this text portion. In this case, the lack of information is indicated by a dagger $(\dagger)$ in place of the reading of the respective witness.

The recording of variants is limited to substantial variants. Thus the apparatus does not contain minor variants that can be interpreted as simple scribal slips unless such variants can be used to infer the existence of significant variants in an exemplar of the respective witness.

The main text of the critical edition was reconstructed through a case-by-case evaluation of the meaning of the text according to the different text versions transmitted in the manuscripts and the parallels transmitted in the Abhidharmakośabhāsyya. The evaluation of variants was as far as possible guided by stemmatical considerations as derived from the results of previous studies in the history of the transmission of the Pātañjalayogaśāstra. ${ }^{88}$

\section{Sigla of Witnesses of the Pātañjalayogaśāstra}

$\mathrm{A}^{\mathrm{d}}$ Digital images of a Xerox copy of a ms. of the Pātañjalayogaśāstra in Devanāgarī script on palm leaf. Lālbhāi Dalpatbhaī Sạ̣skṛti Vidyāmandir, Ahmedabad. Acc. no. 344.

$\mathrm{B}^{\mathrm{d} 1}$ Microfilm images of the Pātañjalayogaśāstra in Devanāgarī script on paper. Central Library, Baroda. Acc. no. 11088, serial no. 64 (in Nambiyar 1942) (ms. no. 1 in Maas 2006, p. xxxix).

$\mathrm{B}^{\mathrm{d} 2}$ Microfilm images of the Pātañjalayogaśāstra in Devanāgarī script on paper. Central Library, Baroda. Acc. no. 341, serial no. 61 (in Nambiyar 1942) (ms. no. 2 in Maas 2006, p. xxxixf.).

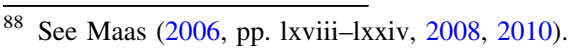




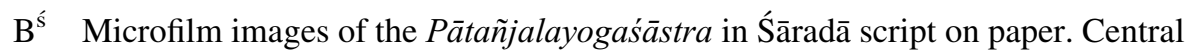
Library, Baroda. Acc. no. 1831, serial no. 62 (in Nambiyar 1942) (ms. no. 3 in Maas 2006, p. xli).

Jai $^{\mathrm{d}}$ Digital images of the Pātañjalayogaśāstra in Devanāgarī script on paper. Maharaja Sawai Man Singh II Museum, Jaipur. Ms. no. 2285 (in Bahura 1976).

$\mathrm{Je}^{\mathrm{d}}$ Digital images of a Xerox copy of a ms. of the Pātañjalayogaśāstra in Devanāgarī script on palm leaf. Manuscript no. 395/2 (in Jambuvijaya 2000).

$\mathrm{K}^{\mathrm{d} 1}$ NGMPP microfilm images of the Pātañjalayogaśāstra in Devanāgarī script on paper. National Archives, Kathmandu. Ms. no. 61, reel no. A 61/11 (ms. no. 5 in Maas 2006, p. xliii).

$\mathrm{K}^{\mathrm{d} 2}$ NGMPP microfilm images of the Pātañjalayogaśāstra in Devanāgarī script on paper. National Archives, Kathmandu. Ms. no. 1-1337, reel no. A 62-32 (ms. no. 6 in Maas 2006, p. xliv).

My ${ }^{\mathrm{t} 3}$ Digital images of the Pātañjalayogaśāstra in Telugu script on palm leaf. Oriental Research Institute, Mysore. Shelf no. P 1560/5, serial no. 35065 (in Marulasiddaiah 1984) (ms. no. 24 in Maas 2006, p. 1xvi).

$\mathrm{P}^{\mathrm{E}}$ The Pātañjalayogaśāstra as edited in Āgāse 1904, p. 124, 1. 9 - p. 132, 1.5 (edition no. 5 in Maas 2006, pp. xxiii-Xxv).

$\mathrm{P}^{\mathrm{d}}$ Digital images of the Pātañjalayogaśāstra in Devanāgarī script on paper. Jayakar Knowledge Resource Centre, Savitribai Phule Pune University (formerly Jayakar Library). Shelf no. 2742 (ms. no. 19 in Maas 2006, p. lix).

$\mathrm{Pc}^{\mathrm{g}}$ Digital images of the Pātañjalayogaśāstra in Grantha script on palm leaf. École française d'Extrême-Orient, Centre de Pondichéry, Pondicherry. Shelf no. 287 (ms. no. 15 in Maas 2006, p. liv).

$\mathrm{Tj}^{\mathrm{g} 1}$ Microfilm print-out of the Pātañjalayogaśāstra in Grantha script on palm leaf. Tanjore Mahārāja Serfoji’s Sarasvatī Mahāl Library, Tanjavur. Serial No. 670 3 (in S. Sastri 1931) (ms. no. 16 in Maas 2006, p. lvf.).

$\mathrm{Tv}^{\mathrm{m}}$ Digital images of the Pātañjalayogaśāstra in Malayālam script on palm leaf. Oriental Research Institute, Thiruvananthapuram (Trivandrum). Shelf no. 622, serial no. 14371 (in Bhaskaran 1984) (ms. no. 21 in Maas 2006, p. lx-lxii).

YVi Basic text commented upon in the Pātañjalayogaśāstravivaraṇa reconstructed from the edition by Polakam Sri Rama Sastri and S.R. Krishnamurthi Sastri. 


\section{Abbreviations Used in the Critically Edited Text Passages}

ac ante correctionem. The reading of a manuscript before a correction was applied.

om. omitted; i. e., the text of the lemma is missing in the listed witness(es).

pc post correctionem; i. e., the reading of a manuscript after a correction was made.

\section{Pātañjalyogaśāstra 3.13 Critically Edited}

[§1] etena bhūtendriyeșu dharmalakṣaṇāvasthāpariṇāmā vyākhyātāḥ (Yogasūtra 3.13). etena pūrvoktena cittapariṇāmena dharmalakṣaṇāvasthārūpeṇa bhūtendriyeṣu dharmapariṇāmo lakṣaṇapariṇāmo 'vasthāpariṇāmaś cokto veditavyaḥ.

Variant Readings: pūrvoktena] $\mathrm{A}^{\mathrm{d}} \mathrm{B}^{\mathrm{d} 1} \mathrm{~B}^{\mathrm{d} 2} \mathrm{~B}^{\mathrm{s}} \mathrm{Jai}^{\mathrm{d}} \mathrm{K}^{\mathrm{d} 1} \mathrm{~K}^{\mathrm{d} 2} \mathrm{Pc}^{\mathrm{g}} \mathrm{P}^{\mathrm{d}} \mathrm{Tj}^{\mathrm{g} 1} \mathrm{Tv}^{\mathrm{m}} \mathrm{P}^{\mathrm{E}} \mathrm{YVi}$; pūrvokta $\mathrm{Je}^{\mathrm{d}} \mathrm{My}^{\mathrm{t} 3}$-pariṇāmena] $\mathrm{A}^{\mathrm{d}} \mathrm{B}^{\mathrm{d} 1} \mathrm{~B}^{\mathrm{d} 2} \mathrm{~B}^{\mathrm{s}} \mathrm{Jai}^{\mathrm{d}} \mathrm{K}^{\mathrm{d} 1} \mathrm{~K}^{\mathrm{d} 2} \mathrm{My}^{\mathrm{t} 3} \mathrm{Pc}^{\mathrm{g}} \mathrm{P}^{\mathrm{d}} \mathrm{Tj}^{\mathrm{g} 1} \mathrm{Tv}^{\mathrm{m}}$ $\mathrm{P}^{\mathrm{E}}$ YVi; parin̄āmenaiva Je ${ }^{\mathrm{d}}$ dharma-] $\mathrm{A}^{\mathrm{d}} \mathrm{B}^{\mathrm{d} 2} \mathrm{~B}^{\mathrm{s}} \mathrm{Jai}^{\mathrm{d}} \mathrm{Je}^{\mathrm{d}} \mathrm{K}^{\mathrm{d} 1} \mathrm{~K}^{\mathrm{d} 2} \mathrm{My}^{\mathrm{t} 3} \mathrm{Pc}^{\mathrm{g}} \mathrm{P}^{\mathrm{d}} \mathrm{Tj}^{\mathrm{g} 1}$ $\mathrm{Tv}^{\mathrm{m}} \mathrm{P}^{\mathrm{E}}$ YVi; svadharma $\mathrm{B}^{\mathrm{d} 1}$-rūpeṇa] $\mathrm{A}^{\mathrm{d}} \mathrm{B}^{\mathrm{d} 1} \mathrm{~B}^{\mathrm{d} 2} \mathrm{~B}^{\mathrm{s}} \mathrm{Jai}^{\mathrm{d}} \mathrm{Je}^{\mathrm{d}} \mathrm{K}^{\mathrm{d} 1} \mathrm{~K}^{\mathrm{d} 2} \mathrm{My}^{\mathrm{t} 3} \mathrm{Pc}^{\mathrm{g}} \mathrm{P}^{\mathrm{d}}$ $\mathrm{Tv}^{\mathrm{m}} \mathrm{P}^{\mathrm{E}} \mathrm{YVi}$; parin̄āmarūpeṇa $\mathrm{Tj}^{\mathrm{g} 1}$

[§2] tatra vyutthānanirodhayor dharmayor abhibhavaprādurbhāvau dharmiṇi dharmapariṇāmah.

Variant Readings: dharmayor] $\mathrm{A}^{\mathrm{d}} \mathrm{Je}^{\mathrm{d}} \mathrm{K}^{\mathrm{d} 1} \mathrm{My}^{\mathrm{t} 3} \mathrm{Pc}^{\mathrm{g}} \mathrm{P}^{\mathrm{d}} \mathrm{TV}^{\mathrm{m}} \quad \mathrm{YVi}$; dvayor dharmayor $\mathrm{B}^{\mathrm{d} 2} \mathrm{~B}^{\mathrm{s}} \mathrm{Jai}^{\mathrm{d}} \mathrm{K}^{\mathrm{d} 2}$; dvayor $\mathrm{B}^{\mathrm{d} 1}$; om. $\mathrm{Tj}^{\mathrm{g} 1} \mathrm{P}^{\mathrm{E}}$ dharmini $] \mathrm{A}^{\mathrm{d}} \mathrm{B}^{\mathrm{d} 1} \mathrm{~B}^{\mathrm{d} 2} \mathrm{~B}^{\mathrm{s}} \mathrm{Jai}^{\mathrm{d}}$ $\mathrm{Je}^{\mathrm{d}} \mathrm{K}^{\mathrm{d} 1} \mathrm{~K}^{\mathrm{d} 2} \mathrm{My}^{\mathrm{t} 3} \mathrm{P}^{\mathrm{d}} \mathrm{P}^{\mathrm{E}}$ YVi; dharmino $\mathrm{Tj}^{\mathrm{g} 1}$; dharminaśs cittasya $\mathrm{Tv}^{\mathrm{m}}$; dharminaś citta Pc ${ }^{\mathrm{g}}$; dharmini citte YVi dharma-] $\mathrm{A}^{\mathrm{d}} \mathrm{B}^{\mathrm{d} 1} \mathrm{~B}^{\mathrm{d} 2} \mathrm{~B}^{\mathrm{s}} \mathrm{Jai}^{\mathrm{d}} \mathrm{Je}^{\mathrm{d}} \mathrm{K}^{\mathrm{d} 1} \mathrm{~K}^{\mathrm{d} 2} \mathrm{My}^{\mathrm{t} 3} \mathrm{P}^{\mathrm{d}} \mathrm{Tj}^{\mathrm{g} 1}$ $\mathrm{Tv}^{\mathrm{m}} \mathrm{P}^{\mathrm{E}} \mathrm{YVi}$; om. $\mathrm{Pc}^{\mathrm{g}}$

[§3] lakșaṇapariṇāmaḥ: nirodhas trilakṣaṇah, tribhir adhvabhir yuktaḥ. sa khalv anāgatalakṣaṇam adhvānam hitvā dharmatvam anatikrānto vartamānaṃ lakṣaṇam pratipannaḥ, yatrāsya svarūpeṇābhivyaktiḥ. eșo 'sya dvitīyo 'dhvā na cātītānāgatābhyāṃ lakșaṇābhyāṃ viyuktaḥ. tathā vyutthānạ̣ trilakṣaṇam, tribhir adhvabhir yuktam, vartamānalakṣaṇaṃ hitvā dharmatvam anatikrāntam atītalakṣaṇam pratipannam. eșo 'sya tṛtīyo 'dhvā na cānāgatavartamānābhyāṃ lakṣaṇābhyāṃ viyuktam. punar vyutthānam upasaṃpadyamānam anāgatalakṣaṇạ̣ hitvā dharmatvam anatikrāntam vartamānalakṣaṇaṃ pratipannam, yatrāsya svarūpābhivyaktau satyāṃ vyāpāraḥ. eșo 'sya dvitīyo 'dhvā na cātītānāgatābhyāṃ lakṣaṇābhyāṃ viyuktam iti. evam punar nirodha evaṃ punar vyutthānam iti.

Variant Readings: lakșaṇapariṇāmaḥ] $\quad \mathrm{A}^{\mathrm{d}} \quad \mathrm{Je}^{\mathrm{d}} \quad \mathrm{My}^{\mathrm{t} 3} \quad \mathrm{Pc}^{\mathrm{g}} \quad \mathrm{Tj}^{\mathrm{g} 1} \quad \mathrm{Tv}^{\mathrm{m}} \quad \mathrm{YVi}$; lakșaṇaparin̄āmaś ca $\mathrm{B}^{\mathrm{d} 1} \mathrm{~B}^{\mathrm{d} 2} \mathrm{~B}^{\hat{s}} \mathrm{Jai}^{\mathrm{d}} \mathrm{K}^{\mathrm{d} 1} \mathrm{~K}^{\mathrm{d} 2} \mathrm{P}^{\mathrm{d}} \mathrm{P}^{\mathrm{E}}$ anāgata-] $\mathrm{B}^{\mathrm{d} 1} \mathrm{~B}^{\mathrm{d} 2} \mathrm{~B}^{\hat{s}} \mathrm{Jai}^{\mathrm{d}} \mathrm{Je}^{\mathrm{d}}$ $\mathrm{K}^{\mathrm{d} 2} \mathrm{P}^{\mathrm{d}} \mathrm{Tj}^{\mathrm{g} 1} \mathrm{Tv}^{\mathrm{m}} \mathrm{P}^{\mathrm{E}} \mathrm{YVi}$; anāgatam $\mathrm{A}^{\mathrm{d}} \mathrm{K}^{\mathrm{d} 1} \mathrm{My}^{\mathrm{t} 3} \mathrm{Pc}^{\mathrm{g}}$ adhvānaṃ] $\mathrm{B}^{\mathrm{d} 2} \mathrm{Je}^{\mathrm{d}} \mathrm{K}^{\mathrm{d} 2} \mathrm{My}^{\mathrm{t} 3}$ 
$\mathrm{Pc}^{\mathrm{g}} \mathrm{Tj}^{\mathrm{g} 1} \mathrm{TV}^{\mathrm{m}} \mathrm{YVi}$; adhvānam prathamam $\mathrm{A}^{\mathrm{d}} \mathrm{B}^{\mathrm{s}} \mathrm{Jai}^{\mathrm{d}} \mathrm{K}^{\mathrm{d} 1} \mathrm{P}^{\mathrm{d}} \mathrm{P}^{\mathrm{E}}$; prathamam adhvānaṃ $\mathrm{B}^{\mathrm{d} 1}$ prathamaṃ $\mathrm{B}^{\mathrm{s}}$ vartamānam] $\mathrm{A}^{\mathrm{d}} \mathrm{B}^{\mathrm{s}} \mathrm{K}^{\mathrm{d} 2} \mathrm{My}^{\mathrm{t} 3} \mathrm{Pc}^{\mathrm{g}} \mathrm{Tj}^{\mathrm{g} 1} \mathrm{P}^{\mathrm{E}}$ (ga gha $\dot{n} a$ ca) YVi; vartamāna $\mathrm{B}^{\mathrm{d} 1} \mathrm{Jai}^{\mathrm{d}} \mathrm{Je}^{\mathrm{d}} \mathrm{K}^{\mathrm{d} 1} \mathrm{P}^{\mathrm{d}} \mathrm{P}^{\mathrm{E}}$ lakșanạạ ... yuktam ] $\mathrm{A}^{\mathrm{d}} \mathrm{B}^{\mathrm{d} 1} \mathrm{~B}^{\mathrm{d} 2} \mathrm{~B}^{\mathrm{s}} \mathrm{Jai}^{\mathrm{d}}$ $\mathrm{Je}^{\mathrm{d}} \mathrm{K}^{\mathrm{d} 1} \mathrm{~K}^{\mathrm{d} 2} \mathrm{My}^{\mathrm{t} 3} \mathrm{Pc}^{\mathrm{g}} \mathrm{P}^{\mathrm{d}} \mathrm{Tv}^{\mathrm{m}} \mathrm{P}^{\mathrm{E}} \mathrm{YVi}$; om. Tj ${ }^{\mathrm{g} 1}$ sva-] $\mathrm{A}^{\mathrm{d}} \mathrm{B}^{\mathrm{d} 2} \mathrm{~B}^{\mathrm{s}} \mathrm{Jai}^{\mathrm{d}} \mathrm{Je}^{\mathrm{d}} \mathrm{K}^{\mathrm{d} 1} \mathrm{~K}^{\mathrm{d} 2} \mathrm{My}^{\mathrm{t} 3}$ $\mathrm{Pc}^{\mathrm{g}} \mathrm{P}^{\mathrm{d}} \mathrm{TV}^{\mathrm{m}} \mathrm{P}^{\mathrm{E}} \mathrm{YVi}$; om. $\mathrm{B}^{\mathrm{d} 1}$; † Tj ${ }^{\mathrm{g} 1}$ na cātîtānāgatābhyām] $\mathrm{A}^{\mathrm{d}} \mathrm{B}^{\mathrm{d} 1} \mathrm{~B}^{\mathrm{d} 2} \mathrm{~B}^{\mathrm{s}} \mathrm{Jai}^{\mathrm{d}} \mathrm{K}^{\mathrm{d} 1}$ $\mathrm{K}^{\mathrm{d} 2} \mathrm{My}^{\mathrm{t} 3} \mathrm{Pc}^{\mathrm{g}} \mathrm{P}^{\mathrm{d}} \mathrm{Tv}^{\mathrm{m}} \mathrm{P}^{\mathrm{E}} \mathrm{YVi}$; nātītānāgatābhyām $\mathrm{Je}^{\mathrm{d}} ; \dagger \mathrm{Tj}^{\mathrm{g} 1}$ viyuktaḥ] $\mathrm{Jai}^{\mathrm{d}} \mathrm{My}^{\mathrm{t} 3}$ $\mathrm{Pc}^{\mathrm{g}} \mathrm{Tv}^{\mathrm{m}} \mathrm{P}^{\mathrm{E}} \mathrm{YVi}$; viyukta iti $\mathrm{A}^{\mathrm{d}}$; vimuktah $\mathrm{B}^{\mathrm{d} 1} \mathrm{~B}^{\mathrm{d} 2} \mathrm{~B}^{\mathrm{s}} \mathrm{Je}^{\mathrm{d}} \mathrm{K}^{\mathrm{d} 1} \mathrm{~K}^{\mathrm{d} 2} \mathrm{P}^{\mathrm{d}}$; $\mathrm{Tj}^{\mathrm{g} 1}$ vartamāna-] $\mathrm{B}^{\mathrm{d} 1} \mathrm{~B}^{\mathrm{d} 2} \mathrm{~B}^{\hat{s}} \mathrm{Je}^{\mathrm{d}} \mathrm{Pc}^{\mathrm{g}} \mathrm{P}^{\mathrm{d}} \mathrm{Tv}^{\mathrm{m}} \mathrm{P}^{\mathrm{E}} \mathrm{YVi}$; vartamānam $\mathrm{A}^{\mathrm{d}} \mathrm{Jai}^{\mathrm{d}} \mathrm{K}^{\mathrm{d} 1} \mathrm{~K}^{\mathrm{d} 2} \mathrm{My}^{\mathrm{t} 3}$ $\mathrm{Tj}^{\mathrm{g} 1} \mathrm{P}^{\mathrm{E}}$ (kha ga gha ina ca) -lakṣaṇam] $\mathrm{A}^{\mathrm{d}} \mathrm{B}^{\mathrm{d} 1} \mathrm{~B}^{\mathrm{d} 2} \mathrm{~B}^{\mathrm{s}} \mathrm{Jai}^{\mathrm{d}} \mathrm{Je}^{\mathrm{d}} \mathrm{K}^{\mathrm{d} 1} \mathrm{~K}^{\mathrm{d} 2} \mathrm{My}^{\mathrm{t} 3} \mathrm{P}^{\mathrm{d}} \mathrm{Tj}^{\mathrm{g} 1}$ $\mathrm{P}^{\mathrm{E}} \mathrm{YVi}$; lakșanạam adhvānam $\mathrm{Pc}^{\mathrm{g}} \mathrm{TV}^{\mathrm{m}}$ dharmatvam anatikrāntam] $\mathrm{A}^{\mathrm{d}} \mathrm{B}^{\mathrm{d} 1} \mathrm{~B}^{\mathrm{d} 2} \mathrm{~B}^{\mathrm{s}}$ $\mathrm{Jai}^{\mathrm{d}} \mathrm{Je}^{\mathrm{d}} \mathrm{K}^{\mathrm{d} 1} \mathrm{~K}^{\mathrm{d} 2} \mathrm{My}^{\mathrm{t} 3} \mathrm{Pc}^{\mathrm{g}} \mathrm{P}^{\mathrm{d}} \mathrm{TV}^{\mathrm{m}} \mathrm{P}^{\mathrm{E}} \mathrm{YVi}$; om. Tj ${ }^{\mathrm{g} 1}$ atīta- $] \mathrm{A}^{\mathrm{d}} \mathrm{B}^{\mathrm{d} 1} \mathrm{~B}^{\mathrm{d} 2} \mathrm{~B}^{\mathrm{s}} \mathrm{Jai}^{\mathrm{d}} \mathrm{Je}^{\mathrm{d}}$ $\mathrm{K}^{\mathrm{d} 2} \mathrm{My}^{\mathrm{t} 3} \mathrm{P}^{\mathrm{d}} \mathrm{Tv}^{\mathrm{m}} \mathrm{P}^{\mathrm{E}} \mathrm{YVi}$; atītam $\mathrm{K}^{\mathrm{d} 1} \mathrm{Pc}^{\mathrm{g}} \mathrm{Tj}^{\mathrm{g} 1}$ eso] $\mathrm{A}^{\mathrm{d}} \mathrm{B}^{\mathrm{d} 1} \mathrm{~B}^{\mathrm{d} 2} \mathrm{~B}^{\mathrm{s}} \mathrm{Jai}^{\mathrm{d}} \mathrm{Je}^{\mathrm{d}} \mathrm{K}^{\mathrm{d} 1} \mathrm{~K}^{\mathrm{d} 2}$ $\mathrm{My}^{\mathrm{t} 3} \mathrm{Pc}^{\mathrm{g}} \mathrm{P}^{\mathrm{d}} \mathrm{Tj}^{\mathrm{g} 1} \mathrm{P}^{\mathrm{E}} \mathrm{YVi}$; om. Tv ${ }^{\mathrm{m}}$ trtìyo] $\mathrm{B}^{\mathrm{d} 1} \mathrm{~B}^{\mathrm{d} 2} \mathrm{~B}^{\mathrm{s}} \mathrm{Jai}^{\mathrm{d}} \mathrm{Je}^{\mathrm{d}} \mathrm{K}^{\mathrm{d} 1} \mathrm{~K}^{\mathrm{d} 2} \mathrm{My}^{\mathrm{t} 3} \mathrm{P}^{\mathrm{d}} \mathrm{Tj}^{\mathrm{g} 1}$ $\mathrm{Tv}^{\mathrm{m}} \mathrm{P}^{\mathrm{E}}$; dvitīyo $\mathrm{A}^{\mathrm{d}} \mathrm{Pc}^{\mathrm{g}} \mathrm{YVi}$ laksanāābhyām] $\mathrm{A}^{\mathrm{d}} \mathrm{B}^{\mathrm{d} 1} \mathrm{~B}^{\mathrm{d} 2} \mathrm{~B}^{\mathrm{s}} \mathrm{Jai}^{\mathrm{d}} \mathrm{K}^{\mathrm{d} 1} \mathrm{~K}^{\mathrm{d} 2} \mathrm{Pc}^{\mathrm{g}} \mathrm{P}^{\mathrm{d}} \mathrm{Tv}^{\mathrm{m}}$ $\mathrm{P}^{\mathrm{E}}$ YVi; om. $\mathrm{Je}^{\mathrm{d}}$; † $\mathrm{My}^{\mathrm{t} 3} \mathrm{Tj}^{\mathrm{g} 1}$ viyuktam] $\mathrm{A}^{\mathrm{d}} \mathrm{Jai}^{\mathrm{d}} \mathrm{Je}^{\mathrm{d}} \mathrm{My}^{\mathrm{t} 3} \mathrm{Pc}^{\mathrm{g}} \mathrm{P}^{\mathrm{E}} \mathrm{YVi}$; viyuktam iti $\mathrm{Tv}^{\mathrm{m}}$; vimuktam $\mathrm{B}^{\mathrm{d} 1} \mathrm{~B}^{\mathrm{s}} \mathrm{K}^{\mathrm{d} 1} \mathrm{~K}^{\mathrm{d} 2} \mathrm{P}^{\mathrm{d}}$; vinirmuktam $\mathrm{B}^{\mathrm{d} 2}$; $\dagger \mathrm{Tj}^{\mathrm{g} 1}$ punar vyutthānam] $\mathrm{A}^{\mathrm{d}} \mathrm{Pc}^{\mathrm{g}}$ YVi; evam punar vyutthānam $\mathrm{B}^{\mathrm{d} 2} \mathrm{~B}^{\mathrm{s}} \mathrm{Jai}^{\mathrm{d}} \mathrm{K}^{\mathrm{d} 1} \mathrm{~K}^{\mathrm{d} 2} \mathrm{P}^{\mathrm{d}} \mathrm{Tv}^{\mathrm{m}} \mathrm{P}^{\mathrm{E}}$; evaṃ vyutthānam punar $\mathrm{Je}^{\mathrm{d}} \mathrm{My}^{\mathrm{t}}$; evaṃ vyutthānam $\mathrm{B}^{\mathrm{d} 1} ; \dagger \mathrm{Tj}^{\mathrm{g} 1}$ upasampadyamānam] $\mathrm{A}^{\mathrm{d}} \mathrm{B}^{\mathrm{d} 1} \mathrm{~B}^{\mathrm{d} 2} \mathrm{~B}^{\mathrm{s}} \mathrm{Jai}^{\mathrm{d}} \mathrm{Je}^{\mathrm{d}} \mathrm{K}^{\mathrm{d} 1} \mathrm{~K}^{\mathrm{d} 2} \mathrm{My}^{\mathrm{t} 3} \mathrm{P}^{\mathrm{d}} \mathrm{Tv}^{\mathrm{m}} \mathrm{P}^{\mathrm{E}} \mathrm{YVi}$; sampadyamānam $\mathrm{Pc}^{\mathrm{g}} ; \dagger \mathrm{Tj}^{\mathrm{g} 1}$ anāgata-] $\mathrm{B}^{\mathrm{d} 1} \mathrm{~B}^{\mathrm{d} 2} \mathrm{Jai}^{\mathrm{d}} \mathrm{Je}^{\mathrm{d}} \mathrm{K}^{\mathrm{d} 1} \mathrm{P}^{\mathrm{E}} \mathrm{YVi}$; anāgatam $\mathrm{A}^{\mathrm{d}} \mathrm{B}^{\hat{s}} \mathrm{~K}^{\mathrm{d} 2} \mathrm{My}^{\mathrm{t} 3} \mathrm{Pc}^{\mathrm{g}} \mathrm{P}^{\mathrm{d}} \mathrm{Tv}^{\mathrm{m}} ; \dagger \mathrm{Tj}^{\mathrm{g} 1}$ vartamāna-]B ${ }^{\mathrm{d} 2} \mathrm{~B}^{\mathrm{s}} \mathrm{Jai}^{\mathrm{d}} \mathrm{Je}^{\mathrm{d}} \mathrm{P}^{\mathrm{d}} \mathrm{P}^{\mathrm{E}} \mathrm{YVi}$; vartamānam $\mathrm{A}^{\mathrm{d}} \mathrm{B}^{\mathrm{d} 1} \mathrm{~K}^{\mathrm{d} 1} \mathrm{~K}^{\mathrm{d} 2} \mathrm{My}^{\mathrm{t} 3} \mathrm{Pc}^{\mathrm{g}} \mathrm{Tv}^{\mathrm{m}}$ $\mathrm{P}^{\mathrm{E}}($ ga gha $\dot{n} a$ ca $)$; † Tj ${ }^{\mathrm{g} 1}$ svarūpābhivyaktau $] \mathrm{A}^{\mathrm{d}} \mathrm{B}^{\mathrm{d} 1} \mathrm{~B}^{\mathrm{d} 2} \mathrm{~B}^{\hat{s}} \mathrm{Jai}^{\mathrm{d}} \mathrm{Je}^{\mathrm{d}} \mathrm{K}^{\mathrm{d} 1} \mathrm{~K}^{\mathrm{d} 2} \mathrm{My}^{\mathrm{t} 3}$ $\mathrm{Pc}^{\mathrm{g}} \mathrm{P}^{\mathrm{d}} \mathrm{P}^{\mathrm{E}}$; svarūpenāanbhivyaktau $\mathrm{Tv}^{\mathrm{m}} \mathrm{YVi} ; \dagger \mathrm{Tj}{ }^{\mathrm{g} 1}$ na cātītānāgatābhyāmạ] $\mathrm{A}^{\mathrm{d}} \mathrm{B}^{\mathrm{d} 1}$ $\mathrm{B}^{\mathrm{d} 2} \mathrm{~B}^{\mathrm{s}} \mathrm{Jai}^{\mathrm{d}} \mathrm{Je}^{\mathrm{d}} \mathrm{K}^{\mathrm{d} 1} \mathrm{~K}^{\mathrm{d} 2} \mathrm{My}^{\mathrm{t} 3} \mathrm{Pc}^{\mathrm{g}} \mathrm{P}^{\mathrm{d}} \mathrm{Tj}^{\mathrm{g} 1} \mathrm{P}^{\mathrm{E}}$ YVi; nātītānāgatābhyām $\mathrm{Tv}^{\mathrm{m}}$ lakșanāābhȳạm] $\mathrm{A}^{\mathrm{d}} \mathrm{B}^{\mathrm{d} 1} \mathrm{~B}^{\mathrm{d} 2} \mathrm{Jai}^{\mathrm{d}} \mathrm{K}^{\mathrm{d} 1} \mathrm{~K}^{\mathrm{d} 2} \mathrm{Pc}^{\mathrm{g}} \mathrm{P}^{\mathrm{d}} \mathrm{Tv}^{\mathrm{m}} \mathrm{P}^{\mathrm{E}} \mathrm{YVi}$; om. $\mathrm{B}^{\mathrm{s}} \mathrm{Je}^{\mathrm{d}} \mathrm{My}^{\mathrm{t} 3} \mathrm{Tj}^{\mathrm{g} 1}$ viyuktam] $\mathrm{A}^{\mathrm{d}} \mathrm{Jai}^{\mathrm{d}} \mathrm{Je}^{\mathrm{d}} \mathrm{My}^{\mathrm{t} 3} \mathrm{Pc}^{\mathrm{g}} \mathrm{Tj}^{\mathrm{g} 1} \mathrm{Tv}^{\mathrm{m}} \mathrm{P}^{\mathrm{E}} \mathrm{YVi}$; vimuktam $\mathrm{B}^{\mathrm{d} 1} \mathrm{~B}^{\mathrm{s}} \mathrm{K}^{\mathrm{d} 1} \mathrm{~K}^{\mathrm{d} 2} \mathrm{P}^{\mathrm{d}}$; vinirmuktam $\mathrm{B}^{\mathrm{d} 2}$ iti] $\mathrm{A}^{\mathrm{d}} \mathrm{B}^{\mathrm{d} 1} \mathrm{~B}^{\mathrm{d} 2} \mathrm{~B}^{\mathrm{s}} \mathrm{Jai}^{\mathrm{d}} \mathrm{Je}^{\mathrm{d}} \mathrm{K}^{\mathrm{d} 1} \mathrm{~K}^{\mathrm{d} 2} \mathrm{My}^{\mathrm{t} 3} \mathrm{Pc}^{\mathrm{g}} \mathrm{P}^{\mathrm{d}} \mathrm{Tj}^{\mathrm{g} 1} \mathrm{Tv}^{\mathrm{m}} \mathrm{P}^{\mathrm{E}} ;$ om. YVi punar nirodha evam] $A^{d} B^{d 1} B^{d 2} B^{s} J a i^{d} J^{d} K^{d 1} K^{d 2} P^{g} P^{d} T^{m} P^{E}$ YVi; punah punar nirodhah $\mathrm{My}^{\mathrm{t}}$; punar vyutthānam evam $\mathrm{Tj}^{\mathrm{g} 1}$ punar $\left.^{2}\right] \mathrm{A}^{\mathrm{d}} \mathrm{B}^{\mathrm{d} 1} \mathrm{~B}^{\mathrm{d} 2} \mathrm{~B}^{\hat{s}}$ $\mathrm{Jai}^{\mathrm{d}} \mathrm{Je}^{\mathrm{d}} \mathrm{K}^{\mathrm{d} 1} \mathrm{~K}^{\mathrm{d} 2} \mathrm{Pc}^{\mathrm{g}} \mathrm{P}^{\mathrm{d}} \mathrm{Tj}^{\mathrm{g} 1} \mathrm{P}^{\mathrm{E}} \mathrm{YVi}$; om. My ${ }^{\mathrm{t} 3} \mathrm{Tv}^{\mathrm{m}}$ vyutthānam] $\mathrm{A}^{\mathrm{d}} \mathrm{B}^{\mathrm{d} 1} \mathrm{~B}^{\mathrm{d} 2} \mathrm{~B}^{\mathrm{s}} \mathrm{Jai}^{\mathrm{d}}$ $\mathrm{Je}^{\mathrm{d}} \mathrm{K}^{\mathrm{d} 1} \mathrm{~K}^{\mathrm{d} 2} \mathrm{My}^{\mathrm{t} 3} \mathrm{Pc}^{\mathrm{g}} \mathrm{P}^{\mathrm{d}} \mathrm{Tv}^{\mathrm{m}} \mathrm{P}^{\mathrm{E}} \mathrm{YVi}$; nirodha $\mathrm{Tj}^{\mathrm{g} 1}$

[§4] tathāvasthāpariṇāmaḥ: nirodhakṣaṇeșu nirodhasaṃskārā balavanto bhavanti, durbalā vyutthānasaṃskārā iti. eșa dharmāṇām avasthāpariṇāmaḥ. tatra dharmiṇo dharmaiḥ pariṇāmaḥ, dharmāṇāṃ tryadhvanāṃ lakṣaṇaị̣ pariṇāmaḥ, lakṣaṇānām apy avasthābhị pariṇāma ity evạ̣ dharmalakṣaṇāvasthāparināmaih śūnyạ̣ na kṣaṇam api guṇavṛttam avatișṭhate. calaṃ guṇavṛttạ̣ guṇasvābhāvyạ̣ tu pravṛttikāraṇam uktạ̣ guṇānām iti.

Variant Readings: nirodha- $\left.{ }^{1}\right] \mathrm{A}^{\mathrm{d}} \mathrm{B}^{\mathrm{d} 1} \mathrm{~B}^{\mathrm{d} 2} \mathrm{~B}^{\mathrm{s}} \mathrm{Je}^{\mathrm{d}} \mathrm{K}^{\mathrm{d} 1} \mathrm{~K}^{\mathrm{d} 2} \mathrm{My}^{\mathrm{t} 3} \mathrm{Pc}^{\mathrm{g}} \mathrm{P}^{\mathrm{d}} \mathrm{Tj}^{\mathrm{g} 1} \mathrm{Tv}^{\mathrm{m}} \mathrm{P}^{\mathrm{E}}$ (ka kha ca) YVi; tatra nirodha $\mathrm{P}^{\mathrm{E}}$; om. Je $\mathrm{J}^{\mathrm{d}}$; J Jai ${ }^{\mathrm{d}}$-kșaṇeșu] $\mathrm{A}^{\mathrm{d}} \mathrm{B}^{\mathrm{d} 1} \mathrm{~K}^{\mathrm{d} 2} \mathrm{Tj}^{\mathrm{g} 1} \mathrm{P}^{\mathrm{E}} \mathrm{YVi}$; lakșaṇeșu $\mathrm{B}^{\mathrm{d} 2} \mathrm{~B}^{\hat{s}}(p c) \mathrm{K}^{\mathrm{d} 1} \mathrm{My}^{\mathrm{t} 3} \mathrm{Pc}^{\mathrm{g}} \mathrm{P}^{\mathrm{d}} \mathrm{Tv}^{\mathrm{m}}$; om. Je $\mathrm{Je}^{\mathrm{d}}$; † Jai ${ }^{\mathrm{d}}$-samskārā balavanto bhavanti] $\mathrm{A}^{\mathrm{d}} \mathrm{B}^{\mathrm{d} 1} \mathrm{~B}^{\mathrm{d} 2} \mathrm{~B}^{\mathrm{s}} \mathrm{Je}^{\mathrm{d}} \mathrm{K}^{\mathrm{d} 1} \mathrm{~K}^{\mathrm{d} 2} \mathrm{My}^{\mathrm{t} 3} \mathrm{Pc}^{\mathrm{g}} \mathrm{P}^{\mathrm{d}} \mathrm{Tj}^{\mathrm{g} 1} \mathrm{P}^{\mathrm{E}} \mathrm{YVi}$; samskāro balavān bhavati $\mathrm{Tv}^{\mathrm{m}}$; † Jai ${ }^{\mathrm{d}}$ iti] $\mathrm{A}^{\mathrm{d}} \mathrm{B}^{\mathrm{d} 1} \mathrm{~B}^{\mathrm{d} 2} \mathrm{~B}^{\hat{\mathrm{s}}} \mathrm{Je}^{\mathrm{d}} \mathrm{K}^{\mathrm{d} 1} \mathrm{~K}^{\mathrm{d} 2} \mathrm{My}^{\mathrm{t} 3} \mathrm{Pc}^{\mathrm{g}} \mathrm{P}^{\mathrm{d}} \mathrm{Tv}^{\mathrm{m}} \mathrm{P}^{\mathrm{E}} \mathrm{YVi}$; bhavanti Tj ${ }^{\mathrm{g} 1}$; † Jai ${ }^{\mathrm{d}}$ esa] $\mathrm{A}^{\mathrm{d}} \mathrm{B}^{\mathrm{d} 1} \mathrm{~B}^{\mathrm{d} 2} \mathrm{~B}^{\mathrm{s}} \mathrm{Je}^{\mathrm{d}} \mathrm{K}^{\mathrm{d} 1} \mathrm{~K}^{\mathrm{d} 2} \mathrm{My}^{\mathrm{t} 3} \mathrm{Pc}^{\mathrm{g}} \mathrm{P}^{\mathrm{d}} \mathrm{Tj}^{\mathrm{g} 1} \mathrm{P}^{\mathrm{E}}$; evam YVi; eva Tv ${ }^{\mathrm{m}}$; † Jai ${ }^{\mathrm{d}}$ dharmaih] $\mathrm{B}^{\mathrm{d} 1} \mathrm{~B}^{\mathrm{d} 2} \mathrm{~B}^{\mathrm{s}} \mathrm{Je}^{\mathrm{d}} \mathrm{K}^{\mathrm{d} 1} \mathrm{~K}^{\mathrm{d} 2} \mathrm{My}^{\mathrm{t} 3} \mathrm{Pc}^{\mathrm{g}} \mathrm{P}^{\mathrm{d}} \mathrm{Tj}^{\mathrm{g} 1} \mathrm{Tv}^{\mathrm{m}} \mathrm{P}^{\mathrm{E}} \mathrm{YVi}$; 
dharma $\mathrm{A}^{\mathrm{d}}$; † Jai ${ }^{\mathrm{d}}$ pariṇāmạ̣ $\left.{ }^{1}\right] \mathrm{A}^{\mathrm{d}} \mathrm{B}^{\mathrm{d} 1} \mathrm{~B}^{\mathrm{d} 2} \mathrm{~B}^{\mathrm{s}} \mathrm{Je}^{\mathrm{d}} \mathrm{K}^{\mathrm{d} 1} \mathrm{~K}^{\mathrm{d} 2} \mathrm{My}^{\mathrm{t} 3} \mathrm{Pc}^{\mathrm{g}} \mathrm{P}^{\mathrm{d}} \mathrm{Tv}^{\mathrm{m}} \mathrm{P}^{\mathrm{E}} \mathrm{YVi}$; parimānāmo dharmmaparin̄āmah $\mathrm{Tj}^{\mathrm{g} 1}$; † Jai ${ }^{\mathrm{d}}$ try- $] \mathrm{A}^{\mathrm{d}} \mathrm{K}^{\mathrm{d} 1} \mathrm{My}^{\mathrm{t}}{ }^{3} \mathrm{Pc}^{\mathrm{g}} \mathrm{Tj}^{\mathrm{g} 1} \mathrm{Tv}^{\mathrm{m}} \mathrm{P}^{\mathrm{E}}$ YVi; om. B $\mathrm{B}^{\mathrm{d} 1} \mathrm{~B}^{\mathrm{d} 2} \mathrm{~B}^{\mathrm{s}} \mathrm{Je}^{\mathrm{d}} \mathrm{K}^{\mathrm{d} 2} \mathrm{P}^{\mathrm{d}}$; † Jai ${ }^{\mathrm{d}}$ pariṇāmah $\left.{ }^{2}\right] \mathrm{A}^{\mathrm{d}} \mathrm{B}^{\mathrm{d} 1} \mathrm{~B}^{\mathrm{d} 2} \mathrm{~B}^{\hat{s}} \mathrm{Je}^{\mathrm{d}} \mathrm{K}^{\mathrm{d} 1} \mathrm{~K}^{\mathrm{d} 2} \mathrm{Pc}^{\mathrm{g}}$ $\mathrm{P}^{\mathrm{d}} \mathrm{Tv}^{\mathrm{m}} \mathrm{P}^{\mathrm{E}}$ YVi; pariṇāmo lakșaṇapariṇāmo $\mathrm{Tj}^{\mathrm{g} 1} ;$ om. $\mathrm{My}^{\mathrm{t} 3}$; † Jai ${ }^{\mathrm{d}}$ apy] $\mathrm{A}^{\mathrm{d}} \mathrm{B}^{\mathrm{d} 1} \mathrm{~B}^{\mathrm{d} 2}$ (pc) $\mathrm{Je}^{\mathrm{d}} \mathrm{K}^{\mathrm{d} 1} \mathrm{~K}^{\mathrm{d} 2} \mathrm{Pc}^{\mathrm{g}} \mathrm{Tj}^{\mathrm{g} 1} \mathrm{Tv}^{\mathrm{m}} \mathrm{P}^{\mathrm{E}} \mathrm{YVi}$; om. $\mathrm{B}^{\mathrm{d} 2}(a c) \mathrm{B}^{\mathrm{s}} \mathrm{My}^{\mathrm{t} 3} \mathrm{P}^{\mathrm{d}}$; † Jai ${ }^{\mathrm{d}}$ pariṇāma] $\mathrm{A}^{\mathrm{d}} \mathrm{B}^{\mathrm{d} 1} \mathrm{~B}^{\mathrm{d} 2} \mathrm{~B}^{\mathrm{s}} \mathrm{Je}^{\mathrm{d}} \mathrm{K}^{\mathrm{d} 1} \mathrm{~K}^{\mathrm{d} 2} \mathrm{My}^{\mathrm{t} 3} \mathrm{Pc}^{\mathrm{g}} \mathrm{P}^{\mathrm{d}} \mathrm{Tv}^{\mathrm{m}} \mathrm{P}^{\mathrm{E}} \mathrm{YVi}$; parin̄āmah avasthāparin̄āma iti $\mathrm{Tj}^{\mathrm{g} 1}$; † Jai ${ }^{\mathrm{d}}$ evam] $\mathrm{A}^{\mathrm{d}} \mathrm{B}^{\mathrm{d} 1} \mathrm{~B}^{\mathrm{d} 2} \mathrm{~B}^{\mathrm{s}} \mathrm{Je}^{\mathrm{d}} \mathrm{K}^{\mathrm{d} 1} \mathrm{~K}^{\mathrm{d} 2} \mathrm{My}^{\mathrm{t} 3} \mathrm{P}^{\mathrm{d}} \mathrm{Tj}^{\mathrm{g} 1} \mathrm{Tv}^{\dot{\mathrm{m}}} \mathrm{P}^{\mathrm{E}} \mathrm{YVi}$; eva $\mathrm{Pc}^{\mathrm{g}}$; $\dagger$ $\mathrm{Jai}^{\mathrm{d}}$ dharma-] $\mathrm{A}^{\mathrm{d}} \mathrm{B}^{\mathrm{d} 1} \mathrm{~B}^{\mathrm{d} 2} \mathrm{~B}^{\mathrm{s}} \mathrm{Je}^{\mathrm{d}} \mathrm{K}^{\mathrm{d} 1} \mathrm{~K}^{\mathrm{d} 2} \mathrm{My}^{\mathrm{t} 3} \mathrm{Pc}^{\mathrm{g}} \mathrm{P}^{\mathrm{d}} \mathrm{Tj}^{\mathrm{g} 1} \mathrm{P}^{\mathrm{E}} \mathrm{YVi}$; $\approx$ dharmānāạ $\mathrm{Tv}^{\mathrm{m}}$; † Jai ${ }^{\mathrm{d}}$ śūnyam na kṣaṇam] $\mathrm{B}^{\mathrm{d} 1} \mathrm{~B}^{\mathrm{s}} \mathrm{K}^{\mathrm{d} 1} \mathrm{~K}^{\mathrm{d} 2} \mathrm{Pc}^{\mathrm{g}} \mathrm{P}^{\mathrm{d}} \mathrm{Tj}^{\mathrm{g} 1} \mathrm{Tv}^{\mathrm{m}} \mathrm{P}^{\mathrm{E}}$; śūnyam lakșaṇam $\mathrm{A}^{\mathrm{d}} \quad \mathrm{B}^{\mathrm{d} 2}$; śūnyam na lakșaṇam $\mathrm{Je}^{\mathrm{d}}$; na śūnyạ̣ lakṣaṇam $\mathrm{My}^{\mathrm{t}}$; aśūnyalakșanạn $\mathrm{YVi}$; † Jai ${ }^{\mathrm{d}}$ calam] $\mathrm{A}^{\mathrm{d}} \mathrm{Tv}^{\mathrm{m}} \mathrm{YVi}$; calad $\mathrm{A}^{\mathrm{d}}$; calam ca $\mathrm{B}^{\mathrm{d} 1} \mathrm{~B}^{\mathrm{d} 2} \mathrm{~B}^{\mathrm{s}}$ $\mathrm{Je}^{\mathrm{d}} \mathrm{K}^{\mathrm{d} 1} \mathrm{~K}^{\mathrm{d} 2} \mathrm{My}^{\mathrm{t} 3} \mathrm{Pc}^{\mathrm{g}} \mathrm{P}^{\mathrm{d}} \mathrm{Tj}^{\mathrm{g} 1} \mathrm{Tv}^{\mathrm{m}} \mathrm{P}^{\mathrm{E}}$; † Jai ${ }^{\mathrm{d}}$-vṛttam] $\mathrm{A}^{\mathrm{d}} \mathrm{B}^{\mathrm{d} 1} \mathrm{~B}^{\mathrm{d} 2} \mathrm{~B}^{\mathrm{s}} \mathrm{Je}^{\mathrm{d}} \mathrm{K}^{\mathrm{d} 1} \mathrm{~K}^{\mathrm{d} 2}$ $\mathrm{My}^{\mathrm{t} 3} \mathrm{Pc}^{\mathrm{g}} \mathrm{P}^{\mathrm{d}} \mathrm{P}^{\mathrm{E}} \mathrm{YVi}$; vrttam iti $\mathrm{Tj}^{\mathrm{g} 1} \mathrm{Tv}^{\mathrm{m}}$; † Jai ${ }^{\mathrm{d}}$ guṇasvābhāvyam tu] $\mathrm{A}^{\mathrm{d}} \mathrm{B}^{\mathrm{d} 1} \mathrm{~B}^{\mathrm{d} 2} \mathrm{~B}^{\mathrm{s}}$ $\mathrm{Je}^{\mathrm{d}} \mathrm{K}^{\mathrm{d} 1} \mathrm{~K}^{\mathrm{d} 2} \mathrm{My}^{\mathrm{t} 3} \mathrm{Pc}^{\mathrm{g}} \mathrm{P}^{\mathrm{d}} \mathrm{Tj}^{\mathrm{g} 1} \mathrm{Tv}^{\mathrm{m}} \mathrm{P}^{\mathrm{E}}$; tu gunasvābhāvyam $\mathrm{YVi}$; † Jai ${ }^{\mathrm{d}}$ uktam $] \mathrm{A}^{\mathrm{d}}$ $\mathrm{B}^{\mathrm{d} 1} \mathrm{~B}^{\mathrm{d} 2} \mathrm{~B}^{\mathrm{s}} \mathrm{Je}^{\mathrm{d}} \mathrm{K}^{\mathrm{d} 1} \mathrm{~K}^{\mathrm{d} 2} \mathrm{My}^{\mathrm{t} 3} \mathrm{P}^{\mathrm{d}} \mathrm{Tj}^{\mathrm{g} 1} \mathrm{Tv}^{\mathrm{m}} \mathrm{P}^{\dot{\mathrm{E}}} \mathrm{YVi}$; om. Pc $\mathrm{Pc}^{\mathrm{g}} ; \dagger \mathrm{Jai}^{\mathrm{d}}$

[§5] etena bhūtendriyeșu dharmadharmibhedāt trividhạ̣ pariṇāmo veditavyaḥ. paramārthatas tv eka eva pariṇāmaḥ, dharmisvarūpamātro hi dharmaḥ, dharmivikriyaivaișā dharmadvārā prapañcyata iti.

Variant Readings: bhūtendriyeșu $] \mathrm{B}^{\mathrm{d} 1} \mathrm{~B}^{\mathrm{d} 2} \mathrm{~B}^{\mathrm{s}} \mathrm{Je}^{\mathrm{d}} \mathrm{K}^{\mathrm{d} 1} \mathrm{~K}^{\mathrm{d} 2} \mathrm{My}^{\mathrm{t} 3} \mathrm{Pc}^{\mathrm{g}} \mathrm{P}^{\mathrm{d}} \mathrm{P}^{\mathrm{E}} \mathrm{YVi}$; bhūtendriyeșu ca $\mathrm{Tj}^{\mathrm{g} 1} \mathrm{Tv}^{\mathrm{m}}$; bhūteșv iṃdriyeșu ca $\mathrm{A}^{\mathrm{d}}$; † Jai ${ }^{\mathrm{d}}$ dharmadharmibhedāt] $\mathrm{A}^{\mathrm{d}} \mathrm{B}^{\mathrm{d} 2} \mathrm{Jai}^{\mathrm{d}} \mathrm{Je}^{\mathrm{d}} \mathrm{K}^{\mathrm{d} 1} \mathrm{~K}^{\mathrm{d} 2} \mathrm{My}^{\mathrm{t} 3} \mathrm{Pc}^{\mathrm{g}} \mathrm{P}^{\mathrm{d}} \mathrm{Tj}^{\mathrm{g} 1} \mathrm{Tv}^{\mathrm{m}} \mathrm{P}^{\mathrm{E}} \mathrm{YVi}$; dharmidharmabhedāt $\mathrm{B}^{\mathrm{d} 1} \mathrm{~B}^{\hat{s}}$ pariṇāmaḥ] $\quad \mathrm{A}^{\mathrm{d}} \quad \mathrm{B}^{\mathrm{d} 1} \quad \mathrm{~B}^{\mathrm{d} 2} \quad \mathrm{~B}^{\mathrm{s}} \quad \mathrm{Jai}^{\mathrm{d}} \mathrm{Je}^{\mathrm{d}} \quad \mathrm{K}^{\mathrm{d} 1} \quad \mathrm{~K}^{\mathrm{d} 2} \quad \mathrm{My}^{\mathrm{t} 3} \quad \mathrm{Pc}^{\mathrm{g}} \quad \mathrm{P}^{\mathrm{d}} \quad \mathrm{Tv}^{\mathrm{m}} \quad \mathrm{P}^{\mathrm{E}} \quad \mathrm{YVi}$; dharmaparin̄āmo $\mathrm{Tj}^{\mathrm{g} 1}$ iti] $\mathrm{A}^{\mathrm{d}} \mathrm{B}^{\mathrm{d} 1} \mathrm{~B}^{\mathrm{d} 2} \mathrm{~B}^{\mathrm{s}} \mathrm{Jai}^{\mathrm{d}} \mathrm{Je}^{\mathrm{d}} \mathrm{K}^{\mathrm{d} 1} \mathrm{~K}^{\mathrm{d} 2} \mathrm{My}^{\mathrm{t} 3} \mathrm{Pc}^{\mathrm{g}} \mathrm{P}^{\mathrm{d}} \mathrm{Tj}^{\mathrm{g} 1} \mathrm{Tv}^{\mathrm{m}} \mathrm{P}^{\mathrm{E}}$; om. YVi

[§6] tatra dharmasya dharmiṇi vartamānasyādhvasv atītānāgatavartamāneṣu bhāvānyathātvaṃ bhavati, na dravyānyathātvam. yathā suvarṇabhājanasya bhittvānyathākriyamāṇasya bhāvānyathātvaṃ bhavati na suvarṇānyathātvam iti. apara āha: "dharmānabhyadhiko dharmī pūrvatattvānatikramāt. pūrvāparāvasthābhedam anupatitạ̣ kauțasthyenaiva parivarteta yady anvaȳ syāt" iti. ayam adoṣaḥ. kasmāt? ekāntatānabhyupagamāt: tad etat trailokyạ̣ vyakter apaiti nityatvapratiședhāt. apetam apy asti vināśapratiședhāt. saṃsargāc cāsya saukṣmyam, saukṣmyāc cānupalabdhir iti.

Variant Readings: vartamānasyādhvasv $] \quad B^{\mathrm{d} 2} \quad \mathrm{Je}^{\mathrm{d}} \quad \mathrm{Pc}^{\mathrm{g}} \quad \mathrm{Tj}^{\mathrm{g} 1} \quad \mathrm{Tv}^{\mathrm{m}} \quad \mathrm{YVi}$; vartamānasyaivādhvasv $\mathrm{A}^{\mathrm{d}} \mathrm{B}^{\mathrm{d} 1} \mathrm{~B}^{\mathrm{s}} \mathrm{Jai}^{\mathrm{d}} \mathrm{K}^{\mathrm{d} 1} \mathrm{~K}^{\mathrm{d} 2} \mathrm{My}^{\mathrm{t} 3} \mathrm{P}^{\mathrm{d}} \mathrm{P}^{\mathrm{E}}$ bhāvānyathātvạ̣] $\mathrm{B}^{\mathrm{d} 1}$ $\mathrm{B}^{\mathrm{d} 2} \mathrm{~B}^{\mathrm{s}} \mathrm{Jai}^{\mathrm{d}} \mathrm{Je}^{\mathrm{d}} \mathrm{K}^{\mathrm{d} 1} \mathrm{~K}^{\mathrm{d} 2} \mathrm{My}^{\mathrm{t} 3} \mathrm{Pc}^{\mathrm{g}} \mathrm{P}^{\mathrm{d}} \mathrm{Tj}^{\mathrm{g} 1} \mathrm{Tv}^{\mathrm{m}} \mathrm{P}^{\mathrm{E}}$ YVi; svabhāvānyathātvạ̣ $\mathrm{A}^{\mathrm{d}}$ bhavati] $\mathrm{A}^{\mathrm{d}} \mathrm{B}^{\mathrm{d} 1} \mathrm{~B}^{\mathrm{d} 2} \mathrm{~B}^{\mathrm{s}} \mathrm{Jai}^{\mathrm{d}} \mathrm{Je}^{\mathrm{d}} \mathrm{K}^{\mathrm{d} 1} \mathrm{~K}^{\mathrm{d} 2} \mathrm{My}^{\mathrm{t} 3} \mathrm{Pc}^{\mathrm{g}} \mathrm{P}^{\mathrm{d}} \mathrm{Tj}^{\mathrm{g} 1} \mathrm{Tv}^{\mathrm{m}} \mathrm{P}^{\mathrm{E}}$; om. YVi na] $\mathrm{A}^{\mathrm{d}}$ $\mathrm{B}^{\mathrm{d} 2} \mathrm{~K}^{\mathrm{d} 1} \mathrm{~K}^{\mathrm{d} 2} \mathrm{My}^{\mathrm{t} 3} \mathrm{Pc}^{\mathrm{g}} \mathrm{Tj}^{\mathrm{g} 1} \mathrm{Tv}^{\mathrm{m}} \mathrm{P}^{\mathrm{E}}$ (ga gha $\dot{n} a$ ca) $\mathrm{YVi}$, na tu $\mathrm{B}^{\mathrm{d} 1} \mathrm{~B}^{\mathrm{s}} \mathrm{P}^{\mathrm{d}} \mathrm{P}^{\mathrm{E}} ;$ om. Je ${ }^{\mathrm{d}} ; \dagger$ $\mathrm{Jai}^{\mathrm{d}}$ bhavati] $\mathrm{A}^{\mathrm{d}} \mathrm{B}^{\mathrm{d} 1} \mathrm{~B}^{\mathrm{d} 2} \mathrm{~B}^{\mathrm{s}} \mathrm{Jai}^{\mathrm{d}} \mathrm{Je}^{\mathrm{d}} \mathrm{K}^{\mathrm{d} 1} \mathrm{~K}^{\mathrm{d} 2} \mathrm{My}^{\mathrm{t} 3} \mathrm{Pc}^{\mathrm{g}} \mathrm{P}^{\mathrm{d}} \mathrm{Tj}^{\mathrm{g} 1} \mathrm{Tv}^{\mathrm{m}} \mathrm{P}^{\mathrm{E}} ;$ om. YVi; $\dagger$ $\mathrm{A}^{\mathrm{d}} \mathrm{Jai}^{\mathrm{d}}$ na] $\mathrm{B}^{\mathrm{d} 2} \mathrm{~B}^{\mathrm{s}} \mathrm{Je}^{\mathrm{d}} \mathrm{K}^{\mathrm{d} 1} \mathrm{~K}^{\mathrm{d} 2} \mathrm{My}^{\mathrm{t} 3} \mathrm{Pc}^{\mathrm{g}} \mathrm{P}^{\mathrm{d}} \mathrm{Tv}^{\mathrm{m}} \mathrm{P}^{\mathrm{E}} \mathrm{YVi}$; na tu $\mathrm{B}^{\mathrm{d} 1}$; na punar $\mathrm{Tj}^{\mathrm{g} 1}$; $\dagger$ $\mathrm{A}^{\mathrm{d}} \mathrm{Jai}^{\mathrm{d}}$ suvarṇānyathātvam] $\mathrm{B}^{\mathrm{d} 1} \mathrm{~B}^{\mathrm{d} 2} \mathrm{~B}^{\mathrm{s}} \mathrm{Je}^{\mathrm{d}} \mathrm{K}^{\mathrm{d} 1} \mathrm{~K}^{\mathrm{d} 2} \mathrm{My}^{\mathrm{t} 3} \mathrm{Pc}^{\mathrm{g}} \mathrm{P}^{\mathrm{d}} \mathrm{Tj}^{\mathrm{g} 1} \mathrm{Tv}^{\mathrm{m}} \mathrm{P}^{\mathrm{E}}$; suvarṇadravyānyathātvam $\mathrm{YVi}$; † $\mathrm{A}^{\mathrm{d}} \mathrm{Jai}^{\mathrm{d}}$ iti] $\mathrm{B}^{\mathrm{d} 1} \mathrm{~B}^{\mathrm{d} 2} \mathrm{~B}^{\mathrm{s}} \mathrm{Jai}^{\mathrm{d}} \mathrm{Je}^{\mathrm{d}} \mathrm{K}^{\mathrm{d} 1} \mathrm{~K}^{\mathrm{d} 2} \mathrm{My}^{\mathrm{t} 3} \mathrm{Pc}^{\mathrm{g}}$ $\mathrm{P}^{\mathrm{d}} \mathrm{Tj}^{\mathrm{g} 1} \mathrm{P}^{\mathrm{E}}$; bhavati $\mathrm{Tv}^{\mathrm{m}}$; $\dagger \mathrm{A}^{\mathrm{d}}$ dharmānabhyadhiko] $\mathrm{B}^{\mathrm{d} 2} \mathrm{~B}^{\mathrm{s}} \mathrm{Jai}^{\mathrm{d}} \mathrm{Je}^{\mathrm{d}} \mathrm{K}^{\mathrm{d} 1} \mathrm{~K}^{\mathrm{d} 2} \mathrm{My}^{\mathrm{t} 3}$ 
$\mathrm{Pc}^{\mathrm{g}} \mathrm{P}^{\mathrm{d}} \mathrm{Tj}^{\mathrm{g} 1} \mathrm{Tv}^{\mathrm{m}} \mathrm{P}^{\mathrm{E}}$; dharmābhyadhiko $\mathrm{B}^{\mathrm{d} 1} \mathrm{YVi} ; \dagger \mathrm{A}^{\mathrm{d}}$ pūrvatattvānatikramāt] $\mathrm{B}^{\mathrm{d} 1}$ $\mathrm{B}^{\mathrm{d} 2} \mathrm{~B}^{\mathrm{s}} \mathrm{Jai}^{\mathrm{d}} \mathrm{Je}^{\mathrm{d}} \mathrm{K}^{\mathrm{d} 1} \mathrm{~K}^{\mathrm{d} 2} \mathrm{My}^{\mathrm{t} 3} \mathrm{Pc}^{\mathrm{g}} \mathrm{P}^{\mathrm{d}} \mathrm{Tj}^{\mathrm{g} 1} \mathrm{Tv}^{\mathrm{m}} \mathrm{P}^{\mathrm{E}}$; pūrvatattvāt anatikrāman $\mathrm{YVi}$; $\dagger$ $\mathrm{A}^{\mathrm{d}}$ kauțasthyenaiva parivarteta] $\mathrm{Je}^{\mathrm{d}} \mathrm{K}^{\mathrm{d} 1} \mathrm{Tv}^{\mathrm{m}} \mathrm{P}^{\mathrm{E}}$; kauțasthyenāpi parivarteta YVi; kauțasthyena viparivartteta $\mathrm{B}^{\mathrm{d} 1} \mathrm{~B}^{\mathrm{d} 2} \mathrm{Jai}^{\mathrm{d}} \mathrm{K}^{\mathrm{d} 2} \mathrm{Pc}^{\mathrm{g}} \mathrm{P}^{\mathrm{d}} \mathrm{Tj}^{\mathrm{g} 1}$; kauțasthyena viparivarttate $\mathrm{B}^{\mathrm{s}} \mathrm{My}^{\mathrm{t} 3} ; \dagger \mathrm{A}^{\mathrm{d}}$ yady ... iti] $\mathrm{B}^{\mathrm{d} 1} \mathrm{~B}^{\mathrm{d} 2} \mathrm{~B}^{\mathrm{s}} \mathrm{Jai}^{\mathrm{d}} \mathrm{Je}^{\mathrm{d}} \mathrm{K}^{\mathrm{d} 1} \mathrm{~K}^{\mathrm{d} 2} \mathrm{Pc}^{\mathrm{g}} \mathrm{P}^{\mathrm{d}} \mathrm{Tj}^{\mathrm{g} 1} \mathrm{TV}^{\mathrm{m}} \mathrm{P}^{\mathrm{E}} \mathrm{YVi}$; om. $\mathrm{My}^{\mathrm{t} 3}$; $† \mathrm{~A}^{\mathrm{d}}$ yady] $\mathrm{B}^{\mathrm{d} 1} \mathrm{~B}^{\mathrm{d} 2} \mathrm{Jai}^{\mathrm{d}} \mathrm{Je}^{\mathrm{d}} \mathrm{K}^{\mathrm{d} 1} \mathrm{~K}^{\mathrm{d} 2} \mathrm{Pc}^{\mathrm{g}} \mathrm{P}^{\mathrm{d}} \mathrm{Tj}^{\mathrm{g} 1} \mathrm{Tv}^{\mathrm{m}} \mathrm{P}^{\mathrm{E}} \mathrm{YVi}$; yady ayam $\mathrm{B}^{\mathrm{s}}$; $\dagger$ $\mathrm{A}^{\mathrm{d}} \mathrm{My}^{\mathrm{t} 3}$ ayam] $\mathrm{B}^{\mathrm{d} 1} \mathrm{~B}^{\mathrm{d} 2} \mathrm{~B}^{\mathrm{s}} \mathrm{Jai}^{\mathrm{d}} \mathrm{Je}^{\mathrm{d}} \mathrm{K}^{\mathrm{d} 1} \mathrm{~K}^{\mathrm{d} 2} \mathrm{My}^{\mathrm{t} 3} \mathrm{P}^{\mathrm{d}} \mathrm{Tj}^{\mathrm{g} 1} \mathrm{Tv}^{\mathrm{m}} \mathrm{P}^{\mathrm{E}} \mathrm{YVi} ;$ om. Pc ${ }^{\mathrm{g}} ; \dagger \mathrm{A}^{\mathrm{d}}$ ekāntatānabhyupagamāt] $\mathrm{B}^{\mathrm{d} 2} \quad \mathrm{~B}^{\mathrm{s}} \mathrm{Jai}^{\mathrm{d}} \mathrm{Je}^{\mathrm{d}} \mathrm{K}^{\mathrm{d} 2} \mathrm{Pc}^{\mathrm{g}} \mathrm{P}^{\mathrm{d}} \mathrm{Tj}^{\mathrm{g} 1} \mathrm{P}^{\mathrm{E}}$; ekāntānabhyupagamāt $\mathrm{B}^{\mathrm{d} 1} \mathrm{~K}^{\mathrm{d} 1} \mathrm{Tv}^{\mathrm{m}} \mathrm{YVi}$; ekāṃtavādānabhyupagamāt $\mathrm{My}^{\mathrm{t}}{ }^{3} ; \dagger \mathrm{A}^{\mathrm{d}}$ vināśa-] $\mathrm{B}^{\mathrm{d} 1} \mathrm{~B}^{\mathrm{d} 2}$ $\mathrm{B}^{\mathrm{s}} \mathrm{Jai}^{\mathrm{d}} \mathrm{Je}^{\mathrm{d}} \mathrm{K}^{\mathrm{d} 1} \mathrm{~K}^{\mathrm{d} 2} \mathrm{My}^{\mathrm{t} 3} \mathrm{Pc}^{\mathrm{g}} \mathrm{P}^{\mathrm{d}} \mathrm{Tj}^{\mathrm{g} 1} \mathrm{P}^{\mathrm{E}} \mathrm{YVi}$; atyantanāśa Tv ${ }^{\mathrm{m}} ; \dagger \mathrm{A}^{\mathrm{d}}$ cāsya] $\mathrm{B}^{\mathrm{d} 1} \mathrm{~B}^{\mathrm{d} 2}$ $\mathrm{B}^{\mathrm{s}} \mathrm{Jai}^{\mathrm{d}} \mathrm{Je}^{\mathrm{d}} \mathrm{K}^{\mathrm{d} 1} \mathrm{~K}^{\mathrm{d} 2} \mathrm{My}^{\mathrm{t} 3} \mathrm{Pc}^{\mathrm{g}} \mathrm{P}^{\mathrm{d}} \mathrm{Tj}^{\mathrm{g} 1} \mathrm{Tv}^{\mathrm{m}} \mathrm{P}^{\mathrm{E}}$; asya $\mathrm{YVi} ; \dagger \mathrm{A}^{\mathrm{d}}$ saukșmyāe] $\mathrm{B}^{\mathrm{d} 1} \mathrm{~B}^{\mathrm{d} 2}$

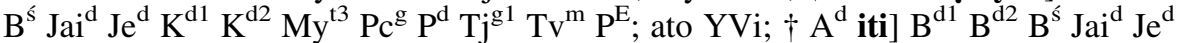
$\mathrm{K}^{\mathrm{d} 1} \mathrm{~K}^{\mathrm{d} 2} \mathrm{My}^{\mathrm{t} 3} \mathrm{P}^{\mathrm{d}} \mathrm{Tj}^{\mathrm{g} 1} \mathrm{Tv}^{\mathrm{m}} \mathrm{P}^{\mathrm{E}} ;$ om. $\mathrm{Pc}^{\mathrm{g}} \mathrm{YVi} ; \dagger \mathrm{A}^{\mathrm{d}}$

[§7] lakṣaṇapariṇāmaḥ: dharmo 'dhvasu vartamāno 'tīto 'tītalakṣaṇayukto 'nāgatavartamānābhyāṃ lakṣaṇābhyām aviyuktah. tathānāgato 'nāgatalakṣaṇayukto vartamānātītābhyāṃ lakṣaṇābhyām aviyuktạ̣. tathā vartamāno vartamānalakșaṇayukto 'tītānāgatābhyām aviyukta iti. yathā puruṣa ekasyāṃ striyāṃ rakto na śeșāsu virakto bhavatīti.

Variant Readings: 'tīto] $\mathrm{B}^{\mathrm{d} 2} \mathrm{~B}^{\mathrm{s}} \mathrm{Je}^{\mathrm{d}} \mathrm{K}^{\mathrm{d} 1} \mathrm{~K}^{\mathrm{d} 2} \mathrm{Pc}^{\mathrm{g}} \mathrm{Tv}^{\mathrm{m}} \mathrm{P}^{\mathrm{E}} \mathrm{YVi}$; om. Jai ${ }^{\mathrm{d}} \mathrm{My}^{\mathrm{t} 3} \mathrm{P}^{\mathrm{d}} \mathrm{Tj}^{\mathrm{g} 1}$; $\dagger \mathrm{A}^{\mathrm{d}} \mathrm{B}^{\mathrm{d} 1}$ lakșanāābhyām] $\mathrm{B}^{\mathrm{d} 2} \mathrm{Je}^{\mathrm{d}} \mathrm{K}^{\mathrm{d} 1} \mathrm{~K}^{\mathrm{d} 2} \mathrm{Pc}^{\mathrm{g}} \mathrm{P}^{\mathrm{d}} \mathrm{Tj}^{\mathrm{g} 1} \mathrm{Tv}^{\mathrm{m}} \mathrm{P}^{\mathrm{E}}$; om. $\mathrm{B}^{\mathrm{d} 1} \mathrm{~B}^{\mathrm{s}} \mathrm{My}^{\mathrm{t} 3}$ $\mathrm{YVi}$; $\dagger \mathrm{A}^{\mathrm{d}} \mathrm{Jai}^{\mathrm{d}}$ aviyuktah! $] \mathrm{B}^{\mathrm{d} 1} \mathrm{Je}^{\mathrm{d}} \mathrm{K}^{\mathrm{d} 2} \mathrm{My}^{\mathrm{t} 3} \mathrm{Tv}^{\mathrm{m}} \mathrm{P}^{\mathrm{E}} \mathrm{YVi}$; api yuktah $\mathrm{Pc}^{\mathrm{g}} \mathrm{Tj}^{\mathrm{g} 1}$; avimuktạ $\mathrm{B}^{\mathrm{d} 2} \mathrm{~B}^{\mathrm{s}} \mathrm{K}^{\mathrm{d} 1} \mathrm{P}^{\mathrm{d}} ; \dagger \mathrm{A}^{\mathrm{d}} \mathrm{Jai}^{\mathrm{d}}$ tathānāgato ... iti] $\mathrm{K}^{\mathrm{d} 2} \mathrm{P}^{\mathrm{E}}$; tathā vartamāno vartamānalakṣaṇayukto 'tītānāgatābhyāṃ lakṣaṇābhyām aviyuktạ tathānāgato 'nāgatalakșaṇayukto vartamānātītābhyāṃ lakșaṇābhyām aviyukta iti $\mathrm{B}^{\mathrm{d} 2} \mathrm{~B}^{\mathrm{s}} \mathrm{Je}^{\mathrm{d}}$ $\mathrm{K}^{\mathrm{d} 1} \mathrm{My}^{\mathrm{t} 3} \mathrm{P}^{\mathrm{d}} \mathrm{Tj}^{\mathrm{g} 1} \mathrm{YVi}$; tathā vartamāno vartamānalakșaṇayukto 'tītānāgatābhyāṃ lakṣaṇābhyām aviyukta iti $\mathrm{Tv}^{\mathrm{m}}$; tathānāgato 'nāgatalakṣaṇayukto vartamānātītābhyāṃ lakșaṇābhyām aviyukta iti $\mathrm{B}^{\mathrm{d} 1} \mathrm{Pc}^{\mathrm{g}}$; (for variant readings of individual words in the preceeding two entries see the following lemmata); $\dagger \mathrm{A}^{\mathrm{d}} \mathrm{Jai}^{\mathrm{d}}$ vartamānātītābhyāmẹ] $\mathrm{B}^{\mathrm{d} 2} \mathrm{Jai}^{\mathrm{d}} \mathrm{Je}^{\mathrm{d}} \mathrm{K}^{\mathrm{d} 1} \mathrm{~K}^{\mathrm{d} 2} \mathrm{My}^{\mathrm{t} 3} \mathrm{Pc}^{\mathrm{g}} \mathrm{P}^{\mathrm{d}} \mathrm{P}^{\mathrm{E}} \mathrm{YVi}$; varttmānātīta $\mathrm{B}^{\mathrm{d} 1}$ $\mathrm{B}^{\mathrm{s}} \mathrm{Tj}^{\mathrm{g} 1}$; † $\mathrm{A}^{\mathrm{d}} \mathrm{TV}{ }^{\mathrm{m}}$ aviyuktaḥ ... 'tītānāgatābhyām] $\mathrm{B}^{\mathrm{d} 2} \mathrm{~B}^{\mathrm{s}} \mathrm{Jai}^{\mathrm{d}} \mathrm{Je}^{\mathrm{d}} \mathrm{K}^{\mathrm{d} 1} \mathrm{~K}^{\mathrm{d} 2} \mathrm{My}^{\mathrm{t} 3} \mathrm{P}^{\mathrm{d}}$ $\mathrm{Tj}^{\mathrm{g} 1} \mathrm{Tv}^{\mathrm{m}} \mathrm{P}^{\mathrm{E}} \mathrm{YVi}$; om. $\mathrm{B}^{\mathrm{d} 1} \mathrm{Pc}^{\mathrm{g}} ; \dagger+\mathrm{A}^{\mathrm{d}}$ aviyuktah $] \mathrm{B}^{\mathrm{d} 2} \mathrm{~B}^{\mathrm{s}} \mathrm{Jai}^{\mathrm{d}} \mathrm{Je}^{\mathrm{d}} \mathrm{K}^{\mathrm{d} 2} \mathrm{My}^{\mathrm{t} 3} \mathrm{Tj}^{\mathrm{g} 1} \mathrm{Tv}^{\mathrm{m}}$ $\mathrm{P}^{\mathrm{E}} \mathrm{YVi}$; avimukta iti $\mathrm{K}^{\mathrm{d} 1} \mathrm{P}^{\mathrm{d}}$; $\dagger \mathrm{A}^{\mathrm{d}} \mathrm{B}^{\mathrm{d} 1} \mathrm{Pc}^{\mathrm{g}}$ 'tītānāgatābhyām] Bś; 'tītānāgatābhyām lakșan̄ābhyām $\mathrm{B}^{\mathrm{d} 2} \mathrm{Jai}^{\mathrm{d}} \mathrm{Je}^{\mathrm{d}} \mathrm{K}^{\mathrm{d} 1} \mathrm{~K}^{\mathrm{d} 2} \mathrm{My}^{\mathrm{t} 3} \mathrm{P}^{\mathrm{d}} \mathrm{Tj}^{\mathrm{g} 1} \mathrm{Tv}^{\mathrm{m}} \mathrm{P}^{\mathrm{E}} \mathrm{YVi} ; \dagger \mathrm{A}^{\mathrm{d}} \mathrm{B}^{\mathrm{d} 1} \mathrm{Pc}^{\mathrm{g}}$ aviyukta] $\mathrm{B}^{\mathrm{d} 2} \mathrm{~B}^{\mathrm{s}} \mathrm{Jai}^{\mathrm{d}} \mathrm{Je}^{\mathrm{d}} \mathrm{K}^{\mathrm{d} 2} \mathrm{My}^{\mathrm{t} 3} \mathrm{P}^{\mathrm{d}} \mathrm{Tv}^{\mathrm{m}} \mathrm{P}^{\mathrm{E}} \mathrm{YVi}$; api yuktah $\mathrm{Tj}^{\mathrm{g} 1}$; avimukta iti $\mathrm{K}^{\mathrm{d} 1} ; \dagger \mathrm{A}^{\mathrm{d}} \mathrm{B}^{\mathrm{d} 1} \mathrm{Pc}^{\mathrm{g}}$ iti] $\mathrm{B}^{\mathrm{d} 1} \mathrm{~B}^{\mathrm{d} 2} \mathrm{~B}^{\hat{s}} \mathrm{Jai}^{\mathrm{d}} \mathrm{Je}^{\mathrm{d}} \mathrm{K}^{\mathrm{d} 1} \mathrm{~K}^{\mathrm{d} 2} \mathrm{Pc}^{\mathrm{g}} \mathrm{P}^{\mathrm{d}} \mathrm{Tj}^{\mathrm{g} 1} \mathrm{Tv}^{\mathrm{m}} \mathrm{P}^{\mathrm{E}} ;$ om. $\mathrm{My}^{\mathrm{t} 3}$

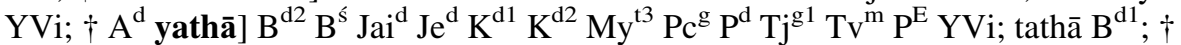
$\mathrm{A}^{\mathrm{d}}$ na śeșāsu] $\mathrm{B}^{\mathrm{d} 1} \mathrm{~B}^{\mathrm{d} 2} \mathrm{~B}^{\mathrm{s}} \mathrm{Jai}^{\mathrm{d}} \mathrm{Je}^{\mathrm{d}} \mathrm{K}^{\mathrm{d} 1} \mathrm{~K}^{\mathrm{d} 2} \mathrm{My}^{\mathrm{t} 3} \mathrm{Pc}^{\mathrm{g}} \mathrm{P}^{\mathrm{d}} \mathrm{Tv}^{\mathrm{m}} \mathrm{P}^{\mathrm{E}} \mathrm{YVi}$; nānyāsv Tj ${ }^{\mathrm{g} 1}$; † $\mathrm{A}^{\mathrm{d}}$ virakto] $\mathrm{B}^{\mathrm{d} 1} \mathrm{~B}^{\mathrm{d} 2} \mathrm{~B}^{\mathrm{s}} \mathrm{Jai}^{\mathrm{d}} \mathrm{Je}^{\mathrm{d}} \mathrm{K}^{\mathrm{d} 1} \mathrm{~K}^{\mathrm{d} 2} \mathrm{My}^{\mathrm{t} 3} \mathrm{Pc}^{\mathrm{g}} \mathrm{P}^{\mathrm{d}} \mathrm{Tv}^{\mathrm{m}} \mathrm{P}^{\mathrm{E}}$; ayukto $\mathrm{Tj}^{\mathrm{g} 1} ; \dagger \mathrm{A}^{\mathrm{d}}$ bhavatīti] $\mathrm{B}^{\mathrm{d} 1} \mathrm{~B}^{\mathrm{d} 2} \mathrm{~B}^{\hat{s}} \mathrm{Jai}^{\mathrm{d}} \mathrm{Je}^{\mathrm{d}} \mathrm{K}^{\mathrm{d} 1} \mathrm{~K}^{\mathrm{d} 2} \mathrm{My}^{\mathrm{t} 3} \mathrm{Pc}^{\mathrm{g}} \mathrm{P}^{\mathrm{d}} \mathrm{Tv}^{\mathrm{m}} \mathrm{P}^{\mathrm{E}}$; bhavati $\mathrm{Tj}{ }^{\mathrm{g} 1} \mathrm{YVi} ; \dagger \mathrm{A}^{\mathrm{d}}$

[§8] "atra lakṣaṇapariṇāme sarvasya sarvalakṣaṇayogād adhvasaṃkaraḥ prāpnoti" iti parair doṣaś codyate. tasya parihāraḥ: dharmāṇạ̣̄ dharmatvam aprasādhyam. sati ca dharmatve lakṣaṇabhedo 'pi vācyaḥ, na vartamānasamaya evāsya dharmasyaikalakṣaṇam. evaṃ hi na cittạ̣ rāgadharmakạ̣ syāt krodhakāle 
rāgasyāsamudācārāt, iti. kiṃca trayāṇāṃ lakṣaṇānāṃ yugapad ekasyāṃ vṛttau nāsti saṃbhavaḥ, krameṇa svavyañjakāñjanasya bhaved iti. uktạ̣ ca: "rūpātiśayā vṛttyatiśayāś ca virudhyante, sāmānyāni tv atiśayaih saha vartante." tasmād asaṃkaraḥ. yathā rāgasyaiva kvacit samudācāra iti na tadānīm anyatrābhāvaḥ, kiṃtu kevalaṃ sāmānyena samanvāgata ity asti tadā tatra tasya bhāvaḥ, tathā lakṣaṇasyeti.

Variant Readings: sarva-] $\mathrm{B}^{\mathrm{d} 1} \mathrm{~B}^{\mathrm{d} 2} \mathrm{~B}^{\mathrm{s}} \mathrm{Jai}^{\mathrm{d}} \mathrm{Je}^{\mathrm{d}} \mathrm{K}^{\mathrm{d} 1} \mathrm{~K}^{\mathrm{d} 2} \mathrm{P}^{\mathrm{d}} \mathrm{Tj}^{\mathrm{g} 1} \mathrm{TV}^{\mathrm{m}} \mathrm{P}^{\mathrm{E}} \mathrm{YVi}$; om. $\mathrm{My}^{\mathrm{t} 3} \mathrm{Pc}^{\mathrm{g}}$; † $\mathrm{A}^{\mathrm{d}}$-yogād] $\mathrm{B}^{\mathrm{d} 1} \mathrm{~B}^{\mathrm{d} 2} \mathrm{~B}^{\mathrm{s}} \mathrm{Jai}^{\mathrm{d}} \mathrm{K}^{\mathrm{d} 1} \mathrm{~K}^{\mathrm{d} 2} \mathrm{My}^{\mathrm{t} 3} \mathrm{P}^{\mathrm{d}} \mathrm{Tj}^{\mathrm{g} 1} \mathrm{P}^{\mathrm{E}} \mathrm{YVi}$; yogād ity Je ${ }^{\mathrm{d}}$ $\mathrm{Pc}^{\mathrm{g}} \mathrm{Tv}^{\mathrm{m}}$; † $\mathrm{A}^{\mathrm{d}}$ prāpnoti iti] $\mathrm{B}^{\mathrm{d} 1} \mathrm{~B}^{\mathrm{d} 2} \mathrm{Jai}^{\mathrm{d}} \mathrm{Je}^{\mathrm{d}} \mathrm{K}^{\mathrm{d} 1} \mathrm{~K}^{\mathrm{d} 2} \mathrm{My}^{\mathrm{t} 3} \mathrm{Pc}^{\mathrm{g}} \mathrm{P}^{\mathrm{d}} \mathrm{Tj}^{\mathrm{g} 1} \mathrm{Tv}^{\mathrm{m}} \mathrm{P}^{\mathrm{E}}$; prāpnoti $\mathrm{B}^{\mathrm{s}}$; om. YVi; $\dagger \mathrm{A}^{\mathrm{d}}$ parair] $\mathrm{B}^{\mathrm{d} 1} \mathrm{~B}^{\mathrm{d} 2} \mathrm{~B}^{\mathrm{s}} \mathrm{Jai}^{\mathrm{d}} \mathrm{Je}^{\mathrm{d}} \mathrm{K}^{\mathrm{d} 1} \mathrm{~K}^{\mathrm{d} 2} \mathrm{My}^{\mathrm{t} 3} \mathrm{Pc}^{\mathrm{g}} \mathrm{P}^{\mathrm{d}} \mathrm{Tv}^{\mathrm{m}} \mathrm{P}^{\mathrm{E}}$ YVi; yah parair $\mathrm{Tj}^{\mathrm{g} 1}$; $\dagger \mathrm{A}^{\mathrm{d}}$ codyate $] \mathrm{Je}^{\mathrm{d}} \mathrm{Pc}^{\mathrm{g}} \mathrm{Tj}^{\mathrm{g} 1} \mathrm{Tv}^{\mathrm{m}} \mathrm{YVi}$; codyata iti $\mathrm{B}^{\mathrm{d} 1} \mathrm{~B}^{\mathrm{s}} \mathrm{Jai}^{\mathrm{d}}$ $\mathrm{K}^{\mathrm{d} 1} \mathrm{~K}^{\mathrm{d} 2} \mathrm{My}^{\mathrm{t} 3} \mathrm{P}^{\mathrm{d}} \mathrm{P}^{\mathrm{E}}$; āpādyata iti $\mathrm{B}^{\mathrm{d} 2}$; $\dagger \mathrm{A}^{\mathrm{d}}$ dharmasyaikalakṣaṇam] $\mathrm{Je}^{\mathrm{d}}$; ekam lakșaṇam dharmasya YVi; dharmatvam $\mathrm{B}^{\mathrm{d} 1} \mathrm{~B}^{\mathrm{d} 2} \mathrm{~B}^{\hat{s}} \mathrm{Jai}^{\mathrm{d}} \mathrm{K}^{\mathrm{d} 1} \mathrm{~K}^{\mathrm{d} 2} \mathrm{My}^{\mathrm{t} 3} \mathrm{Pc}^{\mathrm{g}} \mathrm{P}^{\mathrm{d}} \mathrm{Tj}^{\mathrm{g} 1}$ $\left.\mathrm{Tv}^{\mathrm{m}} \mathrm{P}^{\mathrm{E}} ; \dagger \mathrm{A}^{\mathrm{d}} \mathbf{h i}\right] \mathrm{B}^{\mathrm{d} 1} \mathrm{~B}^{\mathrm{d} 2} \mathrm{~B}^{\hat{s}} \mathrm{Jai}^{\mathrm{d}} \mathrm{Je}^{\mathrm{d}} \mathrm{K}^{\mathrm{d} 1} \mathrm{~K}^{\mathrm{d} 2} \mathrm{P}^{\mathrm{d}} \mathrm{Tj}^{\mathrm{g} 1} \mathrm{P}^{\mathrm{E}} \mathrm{YVi} ;$ om. $\mathrm{My}^{\mathrm{t} 3} \mathrm{Pc}^{\mathrm{g}} \mathrm{Tv}^{\mathrm{m}} ; \dagger$ $\mathrm{A}^{\mathrm{d}}$ rāga-] $\mathrm{B}^{\mathrm{d} 1} \mathrm{~B}^{\mathrm{d} 2} \mathrm{~B}^{\hat{s}} \mathrm{Jai}^{\mathrm{d}} \mathrm{Je}^{\mathrm{d}} \mathrm{K}^{\mathrm{d} 1} \mathrm{~K}^{\mathrm{d} 2} \mathrm{My}^{\mathrm{t} 3} \mathrm{Pc}^{\mathrm{g}} \mathrm{P}^{\mathrm{d}} \mathrm{Tv}^{\mathrm{m}} \mathrm{P}^{\mathrm{E}} \mathrm{YVi}$; rāgādi $\mathrm{Tj}^{\mathrm{g} 1} ; \dagger \mathrm{A}^{\mathrm{d}}$ syāt] $B^{\mathrm{d} 1} \mathrm{~B}^{\mathrm{d} 2} \mathrm{~B}^{\mathrm{s}} \mathrm{Jai}^{\mathrm{d}} \mathrm{Je}^{\mathrm{d}} \mathrm{K}^{\mathrm{d} 1} \mathrm{~K}^{\mathrm{d} 2} \mathrm{My}^{\mathrm{t} 3} \mathrm{Pc}^{\mathrm{g}} \mathrm{P}^{\mathrm{d}} \mathrm{Tj}^{\mathrm{g} 1} \mathrm{Tv}^{\mathrm{m}} \mathrm{P}^{\mathrm{E}}$; kasmāt $\mathrm{YVi}$; † $\mathrm{A}^{\mathrm{d}}$ krodhakāle] $\mathrm{B}^{\mathrm{d} 1} \mathrm{~B}^{\mathrm{d} 2} \mathrm{~B}^{\mathrm{s}} \mathrm{Jai}^{\mathrm{d}} \mathrm{Je}^{\mathrm{d}} \mathrm{K}^{\mathrm{d} 1} \mathrm{~K}^{\mathrm{d} 2} \mathrm{Pc}^{\mathrm{g}} \mathrm{P}^{\mathrm{d}} \mathrm{Tj}^{\mathrm{g} 1} \mathrm{Tv}^{\mathrm{m}} \mathrm{P}^{\mathrm{E}} \mathrm{YVi}$; rāgakāle My ${ }^{\mathrm{t} 3}$; $\mathrm{A}^{\mathrm{d}}$ rāgasyāsamudācārāt] $\mathrm{B}^{\mathrm{d} 1} \mathrm{~B}^{\mathrm{d} 2} \mathrm{~B}^{\mathrm{s}} \mathrm{Jai}^{\mathrm{d}} \mathrm{K}^{\mathrm{d} 1} \mathrm{~K}^{\mathrm{d} 2} \mathrm{Pc}^{\mathrm{g}} \mathrm{P}^{\mathrm{d}} \mathrm{Tj}^{\mathrm{g} 1} \mathrm{TV}^{\mathrm{m}} \mathrm{P}^{\mathrm{E}} \quad \mathrm{YVi}$; rāgasyāsamupācārād Je ${ }^{\mathrm{d}}$; krodhasyāsamudācārād $\mathrm{My}^{\mathrm{t} 3} ; \dagger \mathrm{A}^{\mathrm{d}}$ iti] $\mathrm{B}^{\mathrm{d} 1} \mathrm{~B}^{\mathrm{d} 2} \mathrm{Jai}^{\mathrm{d}} \mathrm{Je}^{\mathrm{d}} \mathrm{K}^{\mathrm{d} 1}$ $\mathrm{K}^{\mathrm{d} 2} \mathrm{My}^{\mathrm{t} 3} \mathrm{Pc}^{\mathrm{g}} \mathrm{P}^{\mathrm{d}} \mathrm{Tj}^{\mathrm{g} 1} \mathrm{Tv}^{\mathrm{m}} \mathrm{P}^{\mathrm{E}} ;$ om. $\mathrm{B}^{\mathrm{s}} \mathrm{YVi} ; \dagger \mathrm{A}^{\mathrm{d}}$ vṛttau] $\mathrm{B}^{\mathrm{d} 1} \mathrm{Je}^{\mathrm{d}} \mathrm{YVi}$; pravṛttau Tv ${ }^{\mathrm{m}}$; vyaktau $\mathrm{B}^{\mathrm{d} 2} \mathrm{~B}^{\mathrm{s}} \mathrm{Jai}^{\mathrm{d}} \mathrm{K}^{\mathrm{d} 1} \mathrm{~K}^{\mathrm{d} 2} \mathrm{My}^{\mathrm{t} 3} \mathrm{Pc}^{\mathrm{g}} \mathrm{P}^{\mathrm{d}} \mathrm{Tj}^{\mathrm{g} 1} \mathrm{P}^{\mathrm{E}} ; \dagger \mathrm{A}^{\mathrm{d}}$ sambhavah] $\mathrm{B}^{\mathrm{d} 1} \mathrm{~B}^{\mathrm{d} 2} \mathrm{~B}^{\mathrm{s}} \mathrm{Jai}^{\mathrm{d}}$ $\mathrm{Je}^{\mathrm{d}} \mathrm{K}^{\mathrm{d} 1} \mathrm{~K}^{\mathrm{d} 2} \mathrm{Pc}^{\mathrm{g}} \mathrm{P}^{\mathrm{d}} \mathrm{Tj}^{\mathrm{g} 1} \mathrm{Tv}^{\mathrm{m}} \mathrm{P}^{\mathrm{E}} \mathrm{YVi}$; sambhava iti $\mathrm{My}^{\mathrm{t}}$; $\dagger \mathrm{A}^{\mathrm{d}}$ kramenana $\mathrm{B}^{\mathrm{d} 1} \mathrm{~B}^{\mathrm{d} 2} \mathrm{~B}^{\mathrm{s}}$ $\mathrm{Jai}^{\mathrm{d}} \mathrm{Je}^{\mathrm{d}} \mathrm{K}^{\mathrm{d} 1} \mathrm{~K}^{\mathrm{d} 2} \mathrm{My}^{\mathrm{t}}{ }^{2} \mathrm{Pc}^{\mathrm{g}} \mathrm{Tj}^{\mathrm{g} 1}$ YVi; kramena tu $\mathrm{P}^{\mathrm{d}} \mathrm{Tv}^{\mathrm{m}} \mathrm{P}^{\mathrm{E}} ; \dagger \mathrm{A}^{\mathrm{d}} \mathrm{Pc}^{\mathrm{g}}$ bhaved] $\mathrm{B}^{\mathrm{d} 2}$ $\mathrm{Tv}^{\mathrm{m}}$ YVi; bhāvo bhaved Jai ${ }^{\mathrm{d}} \mathrm{Je}^{\mathrm{d}} \mathrm{K}^{\mathrm{d} 1} \mathrm{~K}^{\mathrm{d} 2} \mathrm{P}^{\mathrm{d}} \mathrm{P}^{\mathrm{E}}$; bhaved bhāvah $\mathrm{B}^{\mathrm{d} 1} \mathrm{~B}^{\text {ś }} \mathrm{Tj}^{\mathrm{g} 1}$; bhaved iti bhāvah $\mathrm{My}^{\mathrm{t} 3}$; † $\mathrm{A}^{\mathrm{d}} \mathrm{Pc}^{\mathrm{g}}$ iti] $\mathrm{B}^{\mathrm{d} 1} \mathrm{~B}^{\mathrm{d} 2} \mathrm{~B}^{\mathrm{s}} \mathrm{Jai}^{\mathrm{d}} \mathrm{Je}^{\mathrm{d}} \mathrm{K}^{\mathrm{d} 1} \mathrm{~K}^{\mathrm{d} 2} \mathrm{My}^{\mathrm{t} 3} \mathrm{Pc}^{\mathrm{g}} \mathrm{P}^{\mathrm{d}} \mathrm{Tj}^{\mathrm{g} 1} \mathrm{Tv}^{\mathrm{m}} \mathrm{P}^{\mathrm{E}}$; om. YVi; $\left.\dagger \mathrm{A}^{\mathrm{d}} \mathrm{Pc}^{\mathrm{g}} \mathbf{c a}^{2}\right] \mathrm{B}^{\mathrm{d} 2} \mathrm{~B}^{\mathrm{s}} \mathrm{Jai}^{\mathrm{d}} \mathrm{Je}^{\mathrm{d}} \mathrm{K}^{\mathrm{d} 1} \mathrm{~K}^{\mathrm{d} 2} \mathrm{My}^{\mathrm{t} 3} \mathrm{P}^{\mathrm{d}} \mathrm{Tj}^{\mathrm{g} 1} \mathrm{TV}^{\mathrm{m}} \mathrm{P}^{\mathrm{E}} \mathrm{YVi}$; ca paraspareṇa $\mathrm{B}^{\mathrm{d} 1}$; † $\mathrm{A}^{\mathrm{d}} \mathrm{Pc}^{\mathrm{g}}$ sāmānyāni tv] $\mathrm{B}^{\mathrm{d} 1} \mathrm{~B}^{\mathrm{d} 2} \mathrm{~B}^{\mathrm{s}} \mathrm{Jai}^{\mathrm{d}} \mathrm{Je}^{\mathrm{d}} \mathrm{K}^{\mathrm{d} 1} \mathrm{~K}^{\mathrm{d} 2} \mathrm{My}^{\mathrm{t} 3} \mathrm{Pc}^{\mathrm{g}} \mathrm{P}^{\mathrm{d}}$ $\mathrm{Tj}^{\mathrm{g} 1} \mathrm{TV}^{\mathrm{m}} \mathrm{P}^{\mathrm{E}}$; om. $\mathrm{YVi}$; $\mathrm{A}^{\mathrm{d}} \mathrm{Pc}^{\mathrm{g}}$ vartante] $\mathrm{Je}^{\mathrm{d}} \mathrm{YVi}$; vartanta iti $\mathrm{My}^{\mathrm{t} 3} \mathrm{Tj}^{\mathrm{g} 1} \mathrm{Tv}^{\mathrm{m}}$; pravartante $\mathrm{B}^{\mathrm{d} 1} \mathrm{~B}^{\mathrm{d} 2} \mathrm{~B}^{\mathrm{s}} \mathrm{Jai}^{\mathrm{d}} \mathrm{K}^{\mathrm{d} 1} \mathrm{~K}^{\mathrm{d} 2} \mathrm{P}^{\mathrm{d}} \mathrm{P}^{\mathrm{E}} ; \dagger \mathrm{A}^{\mathrm{d}} \mathrm{Pc}^{\mathrm{g}}$ kvacit $] \mathrm{B}^{\mathrm{d} 1} \mathrm{~B}^{\mathrm{d} 2} \mathrm{~B}^{\mathrm{s}} \mathrm{Je}^{\mathrm{d}} \mathrm{K}^{\mathrm{d} 1} \mathrm{~K}^{\mathrm{d} 2}$ $\mathrm{My}^{\mathrm{t} 3} \mathrm{P}^{\mathrm{d}} \mathrm{Tj}^{\mathrm{g} 1} \mathrm{Tv}^{\mathrm{m}} \mathrm{P}^{\mathrm{E}} \mathrm{YVi}$; om. Jai ${ }^{\mathrm{d}}$; $\mathrm{A}^{\mathrm{d}} \mathrm{Pc}^{\mathrm{g}}$ kevalam] $\mathrm{B}^{\mathrm{d} 1} \mathrm{~B}^{\mathrm{d} 2} \mathrm{~B}^{\mathrm{s}} \mathrm{Jai}^{\mathrm{d}} \mathrm{Je}^{\mathrm{d}} \mathrm{K}^{\mathrm{d} 1} \mathrm{~K}^{\mathrm{d} 2}$ $\mathrm{Pc}^{\mathrm{g}} \mathrm{P}^{\mathrm{d}} \mathrm{Tj}^{\mathrm{g} 1} \mathrm{Tv}^{\mathrm{m}} \mathrm{P}^{\mathrm{E}} \mathrm{YVi}$; om. My ${ }^{\mathrm{t} 3}$; $\dagger \mathrm{A}^{\mathrm{d}}$ samanvāgata] $\mathrm{B}^{\mathrm{d} 1} \mathrm{~B}^{\mathrm{d} 2} \mathrm{~B}^{\mathrm{s}} \mathrm{Jai}^{\mathrm{d}} \mathrm{Je}^{\mathrm{d}} \mathrm{K}^{\mathrm{d} 1} \mathrm{~K}^{\mathrm{d} 2}$ $\mathrm{Pc}^{\mathrm{g}} \mathrm{P}^{\mathrm{d}} \mathrm{Tj}^{\mathrm{g} 1} \mathrm{Tv}^{\mathrm{m}} \mathrm{P}^{\mathrm{E}} \mathrm{YVi}$; samanveta $\mathrm{My}^{\mathrm{t} 3}$; $\dagger \mathrm{A}^{\mathrm{d}}$ tadā tatra tasya] $\mathrm{B}^{\mathrm{d} 1} \mathrm{~B}^{\mathrm{s}} \mathrm{Jai}^{\mathrm{d}} \mathrm{K}^{\mathrm{d} 1}$ $\mathrm{K}^{\mathrm{d} 2} \mathrm{P}^{\mathrm{E}}$; tasya tadā tatra $\mathrm{Je}^{\mathrm{d}} \mathrm{Tv}^{\mathrm{m}}$; tadā tasya tatra $\mathrm{B}^{\mathrm{d} 2} \mathrm{Tj}^{\mathrm{g} 1}$; tadā tasya $\mathrm{My}^{\mathrm{t} 3} \mathrm{P}^{\mathrm{d}} \mathrm{YVi}$; $\dagger$ $\mathrm{A}^{\mathrm{d}} \mathrm{Pc}^{\mathrm{g}}$

[§9] na dharmī tryadhvā, dharmās tryadhvānaḥ. te lakṣitā alakṣitāḥ. tatra lakṣitās tāṃ tām avasthāṃ prāpnuvanto 'nyatvena pratinirdiśyante 'vasthāntarato na dravyāntarataḥ. yathaikā rekhā śatasthāne śatam, daśasthāne daśa, ekā caikasthāne. yathā vaikatve 'pi strī "mātā" cocyate "duhitā" ca "svasā" ceti.

Variant Readings: na] $\mathrm{B}^{\mathrm{d} 1} \mathrm{~B}^{\mathrm{d} 2} \mathrm{~B}^{\mathrm{s}} \mathrm{K}^{\mathrm{d} 1} \mathrm{~K}^{\mathrm{d} 2} \mathrm{P}^{\mathrm{d}} \mathrm{P}^{\mathrm{E}} \mathrm{YVi}$; na ca Jai ${ }^{\mathrm{d}}$; tena Je ${ }^{\mathrm{d}}$; om. My $^{\mathrm{t} 3}$ $\mathrm{Tj}^{\mathrm{g} 1} \mathrm{Tv}^{\mathrm{m}} ; \dagger \mathrm{A}^{\mathrm{d}} \mathrm{Pc}^{\mathrm{g}}$ tryadhvā] $\mathrm{B}^{\mathrm{d} 2} \mathrm{Jai}^{\mathrm{d}} \mathrm{Je}^{\mathrm{d}} \mathrm{K}^{\mathrm{d} 1} \mathrm{My}^{\mathrm{t} 3} \mathrm{P}^{\mathrm{d}} \mathrm{Tj}^{\mathrm{g} 1} \mathrm{Tv}^{\mathrm{m}} \mathrm{P}^{\mathrm{E}} \mathrm{YVi}$; adhvā B ${ }^{\mathrm{d} 1}$ $\mathrm{B}^{\hat{s}} \mathrm{~K}^{\mathrm{d} 2} ; \dagger \mathrm{A}^{\mathrm{d}} \mathrm{Pc}^{\mathrm{g}}$ dharmās] Jai ${ }^{\mathrm{d}} \mathrm{My}^{\mathrm{t} 3} \mathrm{Tv}^{\mathrm{m}} \mathrm{YVi}$; dharmās tu $\mathrm{B}^{\mathrm{d} 1} \mathrm{~B}^{\mathrm{d} 2} \mathrm{~B}^{\mathrm{s}} \mathrm{Je}^{\mathrm{d}} \mathrm{K}^{\mathrm{d} 1} \mathrm{~K}^{\mathrm{d} 2}$ $\mathrm{P}^{\mathrm{d}} \mathrm{P}^{\mathrm{E}}$; dharmāś ca Tj ${ }^{\mathrm{g} 1}$; $\dagger \mathrm{A}^{\mathrm{d}} \mathrm{Pc}^{\mathrm{g}}$ try-] $\mathrm{B}^{\mathrm{d} 2} \mathrm{Jai}^{\mathrm{d}} \mathrm{My}^{\mathrm{t} 3} \mathrm{P}^{\mathrm{d}} \mathrm{Tj}^{\mathrm{g} 1} \mathrm{Tv}^{\mathrm{m}} \mathrm{P}^{\mathrm{E}} \mathrm{YVi}$; om. $\mathrm{B}^{\mathrm{d} 1} \mathrm{~B}^{\text {ś }}$ $\mathrm{Je}^{\mathrm{d}} \mathrm{K}^{\mathrm{d} 1} \mathrm{~K}^{\mathrm{d} 2}$; † $\mathrm{A}^{\mathrm{d}} \mathrm{Pc}^{\mathrm{g}}$ lakṣitā alakṣitāḥ tatra lakṣitās] $\mathrm{P}^{\mathrm{d}} \mathrm{Tv}^{\mathrm{m}} \mathrm{P}^{\mathrm{E}}$; lakṣitā alakṣitāś 
ca tatra lakșitās $\mathrm{B}^{\mathrm{d} 1}$; lakṣitāś cālakșitāś ca $\mathrm{Je}^{\mathrm{d}} \mathrm{K}^{\mathrm{d} 1} \mathrm{Tj}^{\mathrm{g} 1}$; lakṣitā alakșitāś ca $\mathrm{B}^{\mathrm{d} 2} \mathrm{~B}^{\mathrm{s}}$ $\mathrm{Jai}^{\mathrm{d}} \mathrm{K}^{\mathrm{d} 2} \mathrm{P}^{\mathrm{E}}$ (ga gha ña ca); lakșitās YVi; † $\left.\mathrm{A}^{\mathrm{d}} \mathrm{My}^{\mathrm{t} 3} \mathrm{Pc}^{\mathrm{g}} \mathbf{t a ̄ m}\right] \mathrm{B}^{\mathrm{d} 1} \mathrm{~B}^{\mathrm{d} 2} \mathrm{~B}^{\text {ś }} \mathrm{Je}^{\mathrm{d}} \mathrm{K}^{\mathrm{d} 1} \mathrm{~K}^{\mathrm{d} 2}$ $\mathrm{P}^{\mathrm{d}} \mathrm{Tj}^{\mathrm{g} 1} \mathrm{Tv}^{\mathrm{m}} \mathrm{P}^{\mathrm{E}} \mathrm{YVi}$; om. Jai ${ }^{\mathrm{d}} ; \dagger \mathrm{A}^{\mathrm{d}} \mathrm{My}^{\mathrm{t} 3} \mathrm{Pc}^{\mathrm{g}}$ yathaikā $] \mathrm{B}^{\mathrm{d} 1} \mathrm{~B}^{\mathrm{d} 2} \mathrm{~B}^{\mathrm{s}} \mathrm{Jai}^{\mathrm{d}} \mathrm{Je}^{\mathrm{d}} \mathrm{K}^{\mathrm{d} 1} \mathrm{~K}^{\mathrm{d} 2}$ $\mathrm{Pc}^{\mathrm{g}} \mathrm{P}^{\mathrm{d}} \mathrm{Tj}^{\mathrm{g} 1} \mathrm{P}^{\mathrm{E}} \mathrm{YVi}$; yathaivaikā $\mathrm{Tv}^{\mathrm{m}} ; \dagger \mathrm{A}^{\mathrm{d}} \mathrm{My}^{\mathrm{t} 3}$ śatam] $\mathrm{B}^{\mathrm{d} 1} \mathrm{~B}^{\mathrm{d} 2} \mathrm{~B}^{\mathrm{s}} \mathrm{Jai}^{\mathrm{d}} \mathrm{Je}^{\mathrm{d}} \mathrm{K}^{\mathrm{d} 1} \mathrm{~K}^{\mathrm{d} 2}$ $\mathrm{Pc}^{\mathrm{g}} \mathrm{P}^{\mathrm{d}} \mathrm{Tv}^{\mathrm{m}} \mathrm{P}^{\mathrm{E}} \mathrm{YVi}$; śatam bhavati $\mathrm{Tj}^{\mathrm{g} 1}$; † $\mathrm{A}^{\mathrm{d}} \mathrm{My}^{\mathrm{t} 3}$ daśa ekā caikasthāne] $\mathrm{B}^{\mathrm{d} 1} \mathrm{~B}^{\mathrm{d} 2}$ $\mathrm{B}^{\mathrm{s}} \mathrm{Jai}^{\mathrm{d}} \mathrm{K}^{\mathrm{d} 1} \mathrm{~K}^{\mathrm{d} 2} \mathrm{P}^{\mathrm{d}} \mathrm{P}^{\mathrm{E}}$; daśa ekāś caikasthāna iti $\mathrm{Pc}^{\mathrm{g}} \mathrm{Tj}^{\mathrm{g} 1}$; daśa caikā ekasthāne Je ${ }^{\mathrm{d}}$; śatasthāne śatam sahasrasthāne sahasrañ ca $\mathrm{Tv}^{\mathrm{m}}$; daśa saiva prathamasthāne ekā $\mathrm{YVi}$; $\mathrm{A}^{\mathrm{d}} \mathrm{My}^{\mathrm{t} 3}$ vaikatve] $\mathrm{Je}^{\mathrm{d}} \mathrm{Pc}^{\mathrm{g}} \mathrm{YVi}$; vā ekaiva Tv ${ }^{\mathrm{m}}$; caikatve $\mathrm{B}^{\mathrm{d} 1} \mathrm{~B}^{\mathrm{d} 2} \mathrm{~B}^{\mathrm{s}} \mathrm{Jai}^{\mathrm{d}} \mathrm{K}^{\mathrm{d} 1}$ $\mathrm{K}^{\mathrm{d} 2} \mathrm{P}^{\mathrm{d}} \mathrm{Tj}^{\mathrm{g} 1} \mathrm{P}^{\mathrm{E}} ; \dagger \mathrm{A}^{\mathrm{d}} \mathrm{My}^{\mathrm{t} 3}$ ceti] $\mathrm{B}^{\mathrm{d} 1} \mathrm{~B}^{\mathrm{d} 2} \mathrm{~B}^{\mathrm{s}} \mathrm{Jai}^{\mathrm{d}} \mathrm{Je}^{\mathrm{d}} \mathrm{K}^{\mathrm{d} 1} \mathrm{~K}^{\mathrm{d} 2} \mathrm{My}^{\mathrm{t} 3} \mathrm{Pc}^{\mathrm{g}} \mathrm{P}^{\mathrm{d}} \mathrm{Tj}^{\mathrm{g} 1} \mathrm{Tv}^{\mathrm{m}} \mathrm{P}^{\mathrm{E}}$; ca $\mathrm{YVi} ; \dagger \mathrm{A}^{\mathrm{d}}$

[§10] avasthāpariṇāme kauțasthyaprasaṅgadoṣa uktah. katham? "adhvano vyāpāreṇa vyavasthitatāḥ. yadā dharmaḥ svavyāpāraṃ na karoti tadānāgatạ̣, yadā karoti tadā vartamānah, yadā kṛtvā nivṛttas tadātīta ity evạ̣ dharmadharmiṇor lakṣaṇānām avasthānāṃ ca kauṭasthyạ̣ prāpnoti” iti doṣa ucyate.

Variant Readings: -doșa] $\mathrm{B}^{\mathrm{d} 1} \mathrm{~B}^{\mathrm{d} 2} \mathrm{~B}^{\mathrm{s}} \mathrm{Jai}^{\mathrm{d}} \mathrm{Je}^{\mathrm{d}} \mathrm{K}^{\mathrm{d} 1} \mathrm{~K}^{\mathrm{d} 2} \mathrm{Pc}^{\mathrm{g}} \mathrm{P}^{\mathrm{d}} \mathrm{Tj}^{\mathrm{g} 1} \mathrm{Tv}^{\mathrm{m}} \mathrm{P}^{\mathrm{E}}$; om. $\mathrm{My}^{\mathrm{t}}{ }^{\text {; }}$; $\dagger \mathrm{A}^{\mathrm{d}}$ uktah] Je $\mathrm{Jy}^{\mathrm{d}} \mathrm{My}^{\mathrm{t}} \mathrm{Pc}^{\mathrm{g}} \mathrm{Tj}^{\mathrm{g} 1} \mathrm{Tv}^{\mathrm{m}} \mathrm{YVi}$; kaiścid uktah $\mathrm{B}^{\mathrm{d} 1} \mathrm{~B}^{\mathrm{d} 2} \mathrm{~B}^{\mathrm{s}} \mathrm{Jai}^{\mathrm{d}} \mathrm{K}^{\mathrm{d} 1} \mathrm{~K}^{\mathrm{d} 2} \mathrm{P}^{\mathrm{d}}$ $\mathrm{P}^{\mathrm{E}}$; † $\mathrm{A}^{\mathrm{d}}$ vyāpāreṇa] $\mathrm{B}^{\mathrm{d} 1} \mathrm{~B}^{\mathrm{d} 2} \mathrm{~B}^{\mathrm{s}} \mathrm{Jai}^{\mathrm{d}} \mathrm{Je}^{\mathrm{d}} \mathrm{K}^{\mathrm{d} 1} \mathrm{~K}^{\mathrm{d} 2} \mathrm{Pc}^{\mathrm{g}} \mathrm{P}^{\mathrm{d}} \mathrm{Tj}^{\mathrm{g} 1} \mathrm{Tv}^{\mathrm{m}} \mathrm{P}^{\mathrm{E}}$; svavyāpāreṇa $\mathrm{A}^{\mathrm{d}} \mathrm{My}^{\mathrm{t} 3}$ YVi vyavasthitatāḥ] $\mathrm{A}^{\mathrm{d}} \mathrm{My}^{\mathrm{t} 3} \mathrm{Pc}^{\mathrm{g}} \mathrm{Tv}^{\mathrm{m}} \mathrm{YVi}$; vyavahitatvāt $\mathrm{B}^{\mathrm{d} 1} \mathrm{~B}^{\mathrm{d} 2} \mathrm{~B}^{\mathrm{s}} \mathrm{Jai}^{\mathrm{d}}$ $\mathrm{Je}^{\mathrm{d}} \mathrm{K}^{\mathrm{d} 1} \mathrm{~K}^{\mathrm{d} 2} \mathrm{P}^{\mathrm{d}} \mathrm{Tj}^{\mathrm{g} 1} \mathrm{P}^{\mathrm{E}}$ sva-] $\mathrm{B}^{\mathrm{d} 1} \mathrm{~B}^{\mathrm{d} 2} \mathrm{~B}^{\mathrm{s}} \mathrm{Jai}^{\mathrm{d}} \mathrm{Je}^{\mathrm{d}} \mathrm{K}^{\mathrm{d} 1} \mathrm{~K}^{\mathrm{d} 2} \mathrm{My}^{\mathrm{t} 3} \mathrm{Pc}^{\mathrm{g}} \mathrm{P}^{\mathrm{d}} \mathrm{Tj}^{\mathrm{g} 1} \mathrm{TV}^{\mathrm{m}} \mathrm{P}^{\mathrm{E}}$ YVi; svam $A^{\mathrm{d}}$ nivruttas] $\mathrm{B}^{\mathrm{d} 1} \mathrm{~B}^{\mathrm{d} 2} \mathrm{~B}^{\mathrm{s}} \mathrm{Jai}^{\mathrm{d}} \mathrm{Je}^{\mathrm{d}} \mathrm{K}^{\mathrm{d} 1} \mathrm{~K}^{\mathrm{d} 2} \mathrm{My}^{\mathrm{t} 3} \mathrm{Pc}^{\mathrm{g}} \mathrm{P}^{\mathrm{d}} \mathrm{Tj}^{\mathrm{g} 1} \mathrm{Tv}^{\mathrm{m}} \mathrm{P}^{\mathrm{E}} \mathrm{YVi}$; vinivṛttas $A^{d}$ evaṃ] $A^{d} B^{d 1} B^{d 2} B^{s} J a i^{d} J^{d} K^{d 1} K^{d 2} P^{g} P^{d} T^{g 1} T^{m} v^{m} P^{E}$; ity eva $\mathrm{My}^{\mathrm{t} 3}$; tena YVi dharmadharmiṇor] $\mathrm{A}^{\mathrm{d}} \mathrm{B}^{\mathrm{d} 1} \mathrm{~B}^{\mathrm{d} 2} \mathrm{~B}^{\mathrm{s}} \mathrm{Jai}^{\mathrm{d}} \mathrm{Je}^{\mathrm{d}} \mathrm{K}^{\mathrm{d} 1} \mathrm{~K}^{\mathrm{d} 2} \mathrm{My}^{\mathrm{t} 3} \mathrm{Pc}^{\mathrm{g}} \mathrm{P}^{\mathrm{d}}$ $\mathrm{Tv}^{\mathrm{m}} \mathrm{P}^{\mathrm{E}}$ dharmiṇo dharmāṇām $\mathrm{Tj}^{\mathrm{g} 1}$; dharmin̄ām nityatvād dharma YVi lakṣaṇānām avasthānāṃ ca] $\mathrm{A}^{\mathrm{d}} \mathrm{B}^{\mathrm{d} 1} \mathrm{~B}^{\mathrm{d} 2} \mathrm{~B}^{\hat{\mathrm{s}}} \mathrm{Jai}^{\mathrm{d}} \mathrm{Je}^{\mathrm{d}} \mathrm{K}^{\mathrm{d} 1} \mathrm{~K}^{\mathrm{d} 2} \mathrm{My}^{\mathrm{t} 3} \mathrm{Pc}^{\mathrm{g}} \mathrm{P}^{\mathrm{d}} \mathrm{Tj}^{\mathrm{g} 1} \mathrm{Tv}^{\mathrm{m}} \mathrm{P}^{\mathrm{E}}$; lakșanāāvasthānām Y YVi doṣa] $\mathrm{B}^{\mathrm{d} 1} \mathrm{~B}^{\mathrm{s}} \mathrm{Je}^{\mathrm{d}} \mathrm{My}^{\mathrm{t} 3} \mathrm{Pc}^{\mathrm{g}} \mathrm{YVi}$; parair doșa $\mathrm{A}^{\mathrm{d}} \mathrm{B}^{\mathrm{d} 2} \mathrm{Jai}^{\mathrm{d}} \mathrm{K}^{\mathrm{d} 1}$ $\mathrm{K}^{\mathrm{d} 2} \mathrm{P}^{\mathrm{d}} \mathrm{Tj}^{\mathrm{g} 1} \mathrm{P}^{\mathrm{E}} ;$ om. $\mathrm{Tv}{ }^{\mathrm{m}}$

[§11] nāsau doṣaḥ. kasmāt? guṇinityatve 'pi guṇānāṃ vimardavaicitryāt. yathā saṃsthānam ādimad dharmamātrạ̣ śabdādīnāṃ vināśy avināśinām, evaṃ lingam ādimad dharmamātrạ̣ guṇānāṃ vināśy avināśinām, tasmin vikārasaṃjñeti.

Variant Readings: nāsau] $\mathrm{B}^{\mathrm{d} 1} \mathrm{~B}^{\mathrm{d} 2} \mathrm{~B}^{\mathrm{s}} \mathrm{Jai}^{\mathrm{d}} \mathrm{Je}^{\mathrm{d}} \mathrm{K}^{\mathrm{d} 1} \mathrm{~K}^{\mathrm{d} 2} \mathrm{My}^{\mathrm{t} 3} \mathrm{Pc}^{\mathrm{g}} \mathrm{P}^{\mathrm{d}} \mathrm{Tj}^{\mathrm{g} 1} \mathrm{Tv}^{\mathrm{m}} \mathrm{P}^{\mathrm{E}} \mathrm{YVi}$; nāyạ̣ $\mathrm{A}^{\mathrm{d}}$ śabdādīnāme ] $\mathrm{A}^{\mathrm{d}} \mathrm{B}^{\mathrm{d} 1} \mathrm{~B}^{\mathrm{d} 2} \mathrm{~B}^{\hat{s}} \mathrm{Je}^{\mathrm{d}} \mathrm{K}^{\mathrm{d} 1} \mathrm{My}^{\mathrm{t} 3} \mathrm{Pc}^{\mathrm{g}} \mathrm{Tj}^{\mathrm{g} 1} \mathrm{Tv}^{\mathrm{m}} \mathrm{P}^{\mathrm{E}}$ (ga gha ña ca) YVi; śabdādīnāṃ guṇānāṃ Jai ${ }^{\mathrm{d}} \mathrm{K}^{\mathrm{d} 2} \mathrm{P}^{\mathrm{d}} \mathrm{P}^{\mathrm{E}}$ guṇānāṃ] $\mathrm{Je}^{\mathrm{d}} \mathrm{My}^{\mathrm{t} 3} \mathrm{YVi}$; sattvādīnāṃ $\mathrm{B}^{\mathrm{d} 1}(a c) \mathrm{My}^{\mathrm{t} 3} \mathrm{Pc}^{\mathrm{g}} \mathrm{P}^{\mathrm{d}} \mathrm{Tj}^{\mathrm{g} 1} \mathrm{Tv}^{\mathrm{m}}$; sattvādīnāṃ gunānāṃ $\mathrm{A}^{\mathrm{d}} \mathrm{B}^{\mathrm{d} 1}(p c) \mathrm{B}^{\mathrm{d} 2} \mathrm{~B}^{\mathrm{s}} \mathrm{Jai}^{\mathrm{d}} \mathrm{K}^{\mathrm{d} 1}$ $K^{\mathrm{d} 2} \mathrm{P}^{\mathrm{E}}$-saṃjñeti] $\mathrm{B}^{\mathrm{d} 1} \mathrm{~B}^{\mathrm{d} 2} \mathrm{~B}^{\mathrm{s}} \mathrm{Jai}^{\mathrm{d}} \mathrm{Je}^{\mathrm{d}} \mathrm{K}^{\mathrm{d} 1} \mathrm{~K}^{\mathrm{d} 2} \mathrm{My}^{\mathrm{t} 3} \mathrm{Pc}^{\mathrm{g}} \mathrm{P}^{\mathrm{d}} \mathrm{Tj}^{\mathrm{g} 1} \mathrm{Tv}^{\mathrm{m}} \mathrm{P}^{\mathrm{E}} \mathrm{YVi}$; saṃjñā $\mathrm{A}^{\mathrm{d}}$

[§12] tatrodāharaṇam: mṛddharmī piṇụākārād dharmād dharmāntaram upasampadyamāno dharmatạ pariṇamate ghațākāra iti. ghațākāro 'nāgatam lakṣaṇaṃ hitvā vartamānaṃ lakṣaṇaṃ pratipadyata iti lakșaṇatạ pariṇamate. ghațo navapurāṇatāṃ pratikṣaṇam anubhavann avasthāpariṇāmaṃ pratipadyata iti. dharmiṇo 'pi dharmāntaram avasthā dharmasyāpi lakṣaṇāntaram avasthā, ity eka eva pariṇāmo bhedenopadarśita iti. evaṃ padārthāntareṣv api yojyam iti. 
Variant Readings: tatrodāharanam] $\mathrm{A}^{\mathrm{d}} \mathrm{Je}^{\mathrm{d}} \mathrm{My}^{\mathrm{t} 3} \mathrm{Pc}^{\mathrm{g}} \mathrm{Tj}^{\mathrm{g} 1} \mathrm{Tv}^{\mathrm{m}} \mathrm{YVi}$; tatredam udāharanam $\mathrm{B}^{\mathrm{d} 1} \mathrm{~B}^{\mathrm{d} 2} \mathrm{~B}^{\mathrm{s}} \mathrm{Jai}^{\mathrm{d}} \mathrm{K}^{\mathrm{d} 1} \mathrm{~K}^{\mathrm{d} 2} \mathrm{P}^{\mathrm{d}} \mathrm{P}^{\mathrm{E}}$ pinḍākārād] $\mathrm{A}^{\mathrm{d}} \mathrm{B}^{\mathrm{d} 1} \mathrm{~B}^{\mathrm{d} 2} \mathrm{~B}^{\mathrm{s}} \mathrm{Jai}^{\mathrm{d}} \mathrm{Je}^{\mathrm{d}} \mathrm{K}^{\mathrm{d} 1}$ $\mathrm{K}^{\mathrm{d} 2} \mathrm{P}^{\mathrm{d}} \mathrm{P}^{\mathrm{E}}$ YVi; piṇ̣ākārah $\mathrm{Pc}^{\mathrm{g}} \mathrm{Tv}^{\mathrm{m}}$; om. $\mathrm{My}^{\mathrm{t}}{ }^{\dot{3}} \mathrm{Tj}^{\mathrm{g} 1}$ dharmād dharmāntaram] $\mathrm{B}^{\mathrm{d} 1}$ $\mathrm{B}^{\mathrm{d} 2} \mathrm{~B}^{\mathrm{s}} \mathrm{Jai}^{\mathrm{d}} \mathrm{K}^{\mathrm{d} 1} \mathrm{~K}^{\mathrm{d} \dot{2}} \mathrm{P}^{\mathrm{d}} \mathrm{P}^{\dot{\mathrm{E}}}$; dharmāmutaram $\mathrm{A}^{\mathrm{d}}$; piṃụataram $\mathrm{Je}^{\mathrm{d}}$; piṇụākaram $\mathrm{My}^{\mathrm{t} 3}$ $\mathrm{Tj}^{\mathrm{g} 1} \mathrm{Tv}^{\mathrm{m}}$; piṃụāntam Pc $\mathrm{c}^{\mathrm{g}}$; ākārantaram YVi ghațākāra iti] $\mathrm{B}^{\mathrm{d} 1} \mathrm{~B}^{\mathrm{d} 2} \mathrm{~B}^{\mathrm{s}} \mathrm{Jai}^{\mathrm{d}} \mathrm{K}^{\mathrm{d} 1} \mathrm{~K}^{\mathrm{d} 2}$ $\mathrm{My}^{\mathrm{t} 3} \mathrm{P}^{\mathrm{E}}$; ghatākāram $\mathrm{A}^{\mathrm{d}}$; piṇụaghațākāreṇa $\mathrm{Tj}^{\mathrm{g} 1}$; om. $\mathrm{Je}^{\mathrm{d}} \mathrm{Pc}^{\mathrm{g}} \mathrm{P}^{\mathrm{d}} \mathrm{TV}^{\mathrm{m}} \quad \mathrm{YVi}$ ghațākāro ... parinamate] $\mathrm{A}^{\mathrm{d}} \mathrm{B}^{\mathrm{d} 1} \mathrm{~B}^{\mathrm{d} 2} \mathrm{~B}^{\mathrm{s}} \mathrm{Jai}^{\mathrm{d}} \mathrm{Je}^{\mathrm{d}} \mathrm{K}^{\mathrm{d} 1} \mathrm{~K}^{\mathrm{d} 2} \mathrm{My}^{\mathrm{t} 3} \mathrm{Pc}^{\mathrm{g}} \mathrm{P}^{\mathrm{d}} \mathrm{Tj}^{\mathrm{g} 1} \mathrm{Tv}^{\mathrm{m}}$ $\mathrm{P}^{\mathrm{E}}$; om. YVi ghațākāro] $\mathrm{A}^{\mathrm{d}} \mathrm{B}^{\mathrm{d} 1} \mathrm{~B}^{\mathrm{d} 2} \mathrm{~B}^{\mathrm{s}} \mathrm{Jai}^{\mathrm{d}} \mathrm{Je}^{\mathrm{d}} \mathrm{K}^{\mathrm{d} 1} \mathrm{~K}^{\mathrm{d} 2} \mathrm{Pc}^{\mathrm{g}} \mathrm{P}^{\mathrm{d}} \mathrm{Tj}^{\mathrm{g} 1} \mathrm{Tv}^{\mathrm{m}} \mathrm{P}^{\mathrm{E}}$; om. $\mathrm{My}^{\mathrm{t} 3}$; † YVi 'nāgatam ] $\mathrm{A}^{\mathrm{d}} \mathrm{B}^{\mathrm{d} 1} \mathrm{~B}^{\mathrm{d} 2} \mathrm{~B}^{\mathrm{s}} \mathrm{Jai}^{\mathrm{d}} \mathrm{Je}^{\mathrm{d}} \mathrm{K}^{\mathrm{d} 1} \mathrm{~K}^{\mathrm{d} 2} \mathrm{Pc}^{\mathrm{g}} \mathrm{P}^{\mathrm{d}} \mathrm{Tj}^{\mathrm{g} 1} \mathrm{P}^{\mathrm{E}}$; nāgata $\mathrm{My}^{\mathrm{t} 3}$ $\mathrm{Tv}^{\mathrm{m}}$; † YVi vartamānam] $\mathrm{A}^{\mathrm{d}} \mathrm{Jai}^{\mathrm{d}} \mathrm{Je}^{\mathrm{d}} \mathrm{K}^{\mathrm{d} 1} \mathrm{My}^{\mathrm{t} 3} \mathrm{Pc}^{\mathrm{g}} \mathrm{P}^{\mathrm{d}}$; vartamāna $\mathrm{B}^{\mathrm{d} 1} \mathrm{~B}^{\mathrm{d} 2} \mathrm{~B}^{\mathrm{s}} \mathrm{K}^{\mathrm{d} 2}$ $\mathrm{Tj}^{\mathrm{g} 1} \mathrm{Tv}^{\mathrm{m}} \mathrm{P}^{\mathrm{E}}$; † YVi ghațo] $\mathrm{A}^{\mathrm{d}} \mathrm{B}^{\mathrm{d} 1} \mathrm{~B}^{\mathrm{d} 2} \mathrm{~B}^{\mathrm{s}} \mathrm{Jai}^{\mathrm{d}} \mathrm{Je}^{\mathrm{d}} \mathrm{K}^{\mathrm{d} 1} \mathrm{~K}^{\mathrm{d} 2} \mathrm{My}^{\mathrm{t} 3} \mathrm{Pc}^{\mathrm{g}} \mathrm{Tv}^{\mathrm{m}} \mathrm{P}^{\mathrm{E}} \mathrm{YVi}$; ghatākaro $\mathrm{Tj}^{\mathrm{g} 1}$; om. $\mathrm{P}^{\mathrm{d}}$ pratikṣaṇam] $\mathrm{A}^{\mathrm{d}} \mathrm{B}^{\mathrm{d} 1} \mathrm{~B}^{\mathrm{s}} \mathrm{K}^{\mathrm{d} 1} \mathrm{~K}^{\mathrm{d} 2} \mathrm{Tj}^{\mathrm{g} 1} \mathrm{Tv}^{\mathrm{m}} \mathrm{P}^{\mathrm{E}} \mathrm{YVi}$; pratilakșanam $\mathrm{Je}^{\mathrm{d}} \mathrm{My}^{\mathrm{t} 3} \mathrm{Pc}^{\mathrm{g}} \mathrm{P}^{\mathrm{d}}$; om. $\mathrm{B}^{\mathrm{d} 2} \mathrm{Jai}^{\mathrm{d}}$ avasthāparin̄āmam $] \mathrm{A}^{\mathrm{d}} \mathrm{B}^{\mathrm{d} 1} \mathrm{~B}^{\mathrm{d} 2} \mathrm{~B}^{\mathrm{s}} \mathrm{Jai}^{\mathrm{d}}$ $\mathrm{Je}^{\mathrm{d}} \mathrm{K}^{\mathrm{d} 1} \mathrm{~K}^{\mathrm{d} 2} \mathrm{My}^{\mathrm{t} 3} \mathrm{Pc}^{\mathrm{g}} \mathrm{P}^{\mathrm{d}} \mathrm{Tv}^{\mathrm{m}} \mathrm{P}^{\mathrm{E}} \mathrm{YVi}$; avasthātah parināmam $\mathrm{Tj}^{\mathrm{g} 1}$ pratipadyata iti] $\mathrm{A}^{\mathrm{d}} \mathrm{B}^{\mathrm{d} 1} \mathrm{~B}^{\mathrm{d} 2} \mathrm{~B}^{\mathrm{s}} \mathrm{Jai}^{\mathrm{d}} \mathrm{Je}^{\mathrm{d}} \mathrm{K}^{\mathrm{d} 1} \mathrm{~K}^{\mathrm{d} 2} \mathrm{My}^{\mathrm{t} 3} \mathrm{Pc}^{\mathrm{g}} \mathrm{P}^{\mathrm{d}} \mathrm{Tv}^{\mathrm{m}} \mathrm{P}^{\mathrm{E}}$ YVi; anubhavati $\mathrm{Tj}^{\mathrm{g} 1}$ dharmasyāpi] $\mathrm{A}^{\mathrm{d}} \mathrm{B}^{\mathrm{d} 1} \mathrm{~B}^{\mathrm{d} 2} \mathrm{~B}^{\mathrm{s}} \mathrm{Jai}^{\mathrm{d}} \mathrm{Je}^{\mathrm{d}} \mathrm{K}^{\mathrm{d} 1} \mathrm{~K}^{\mathrm{d} 2} \mathrm{My}^{\mathrm{t} 3} \mathrm{Pc}^{\mathrm{g}} \mathrm{P}^{\mathrm{d}} \mathrm{Tv}^{\mathrm{m}} \mathrm{P}^{\mathrm{E}} \mathrm{YVi}$; dharmasya $\mathrm{Tj}^{\mathrm{g} 1}$ avasthā ity] $\mathrm{A}^{\mathrm{d}} \mathrm{B}^{\mathrm{d} 1} \mathrm{~B}^{\mathrm{d} 2} \mathrm{~B}^{\mathrm{s}} \mathrm{Jai}^{\mathrm{d}} \mathrm{Je}^{\mathrm{d}} \mathrm{K}^{\mathrm{d} 1} \mathrm{~K}^{\mathrm{d} 2} \mathrm{My}^{\mathrm{t} 3} \mathrm{Pc}^{\mathrm{g}} \mathrm{P}^{\mathrm{d}} \mathrm{Tj}^{\mathrm{g} 1} \mathrm{Tv}^{\mathrm{m}} \mathrm{P}^{\mathrm{E}}$; avasthā tata YVi eva] $\mathrm{A}^{\mathrm{d}} \mathrm{B}^{\mathrm{d} 1} \mathrm{~B}^{\mathrm{d} 2} \mathrm{~B}^{\mathrm{s}} \mathrm{Jai}^{\mathrm{d}} \mathrm{Je}^{\mathrm{d}} \mathrm{K}^{\mathrm{d} 1} \mathrm{~K}^{\mathrm{d} 2} \mathrm{My}^{\mathrm{t} 3} \mathrm{Pc}^{\mathrm{g}} \mathrm{P}^{\mathrm{d}} \mathrm{TV}^{\mathrm{m}} \mathrm{P}^{\mathrm{E}} ;$ om. $\mathrm{Tj}^{\mathrm{g} 1}$ pariṇāmo] $\mathrm{A}^{\mathrm{d}} \mathrm{B}^{\mathrm{d} 1} \mathrm{~B}^{\mathrm{d} 2} \mathrm{~B}^{\hat{s}} \mathrm{Je}^{\mathrm{d}} \mathrm{K}^{\mathrm{d} 1} \mathrm{~K}^{\mathrm{d} 2} \mathrm{My}^{\mathrm{t} 3} \mathrm{Pc}^{\mathrm{g}} \mathrm{Tj}^{\mathrm{g} 1} \mathrm{Tv}^{\mathrm{m}} \mathrm{YVi}$; dravyapariṇāmo Jai ${ }^{\mathrm{d}}$ $\mathrm{P}^{\mathrm{d}} \mathrm{P}^{\dot{E}}$ bhedenopa- $] \mathrm{A}^{\mathrm{d}} \mathrm{B}^{\mathrm{d} 1} \mathrm{~B}^{\mathrm{d} 2} \mathrm{~B}^{\mathrm{s}} \mathrm{Jai}^{\mathrm{d}} \mathrm{Je}^{\mathrm{d}} \mathrm{K}^{\mathrm{d} 1} \mathrm{~K}^{\mathrm{d} 2} \mathrm{My}^{\mathrm{t} 3} \mathrm{P}^{\mathrm{d}} \mathrm{Tj}^{\mathrm{g} 1} \mathrm{TV}^{\mathrm{m}} \mathrm{P}^{\mathrm{E}} \mathrm{YVi}$; bhedena Pc ${ }^{\mathrm{g}}$ iti] $\mathrm{A}^{\mathrm{d}} \mathrm{B}^{\mathrm{d} 2} \mathrm{Jai}^{\mathrm{d}} \mathrm{Je}^{\mathrm{d}} \mathrm{K}^{\mathrm{d} 1} \mathrm{~K}^{\mathrm{d} 2} \mathrm{My}^{\mathrm{t} 3} \mathrm{Pc}^{\mathrm{g}} \mathrm{P}^{\mathrm{d}} \mathrm{Tj}^{\mathrm{g} 1} \mathrm{TV}^{\mathrm{m}} \mathrm{P}^{\mathrm{E}} \mathrm{YVi}$; om. $\mathrm{B}^{\mathrm{d} 1} \mathrm{~B}^{\text {ś }}$ iti] $\mathrm{A}^{\mathrm{d}} \mathrm{B}^{\mathrm{d} 1} \mathrm{~B}^{\mathrm{d} 2} \mathrm{~B}^{\mathrm{s}} \mathrm{Jai}^{\mathrm{d}} \mathrm{Je}^{\mathrm{d}} \mathrm{K}^{\mathrm{d} 1} \mathrm{~K}^{\mathrm{d} 2} \mathrm{My}^{\mathrm{t} 3} \mathrm{Pc}^{\mathrm{g}} \mathrm{P}^{\mathrm{d}} \mathrm{TV}^{\mathrm{m}} \mathrm{P}^{\mathrm{E}} ;$ om. $\mathrm{Tj}^{\mathrm{g} 1} \mathrm{YVi}$

[§13] ta ete dharmalakṣaṇāvasthāpariṇāmā dharmisvarūpam anatikrāntā ity eka eva parin̄āmah sarvān amūn viśeșān abhiplavate: avasthitasya dravyasya pūrvadharmanivṛttau dharmāntarotpattị pariṇāma iti.

Variant Readings: ta ete] $\mathrm{A}^{\mathrm{d}} \mathrm{B}^{\mathrm{d} 1} \mathrm{~B}^{\mathrm{d} 2} \mathrm{Jai}^{\mathrm{d}} \mathrm{Je}^{\mathrm{d}} \mathrm{K}^{\mathrm{d} 1} \mathrm{~K}^{\mathrm{d} 2} \mathrm{My}^{\mathrm{t} 3} \mathrm{P}^{\mathrm{d}} \mathrm{Tv}^{\mathrm{m}} \mathrm{P}^{\mathrm{E}} \mathrm{YVi}$; ata ete $\mathrm{Tj}^{\mathrm{g} 1}$; ete $\mathrm{My}^{\mathrm{t} 3} \mathrm{Pc}^{\mathrm{g}}$; etena $\mathrm{B}^{\mathrm{s}}$ dharmalakșaṇāvasthā-] $\mathrm{A}^{\mathrm{d}} \mathrm{B}^{\mathrm{d} 1} \mathrm{~B}^{\mathrm{d} 2} \mathrm{~B}^{\mathrm{s}} \mathrm{Jai}^{\mathrm{d}} \mathrm{Je}^{\mathrm{d}} \mathrm{K}^{\mathrm{d} 1} \mathrm{~K}^{\mathrm{d} 2}$ $\mathrm{Pc}^{\mathrm{g}} \mathrm{P}^{\mathrm{d}} \mathrm{Tj}^{\mathrm{g} 1} \mathrm{Tv}^{\mathrm{m}} \mathrm{P}^{\mathrm{E}} \mathrm{YVi}$; lakșaṇadharmāivasthā My ${ }^{\mathrm{t} 3}$-pariṇāmāa $] \mathrm{B}^{\mathrm{d} 1} \mathrm{~B}^{\mathrm{d} 2} \mathrm{~B}^{\mathrm{s}} \mathrm{Jai}^{\mathrm{d}} \mathrm{Je}^{\mathrm{d}}$ $\mathrm{K}^{\mathrm{d} 1} \mathrm{~K}^{\mathrm{d} 2} \mathrm{My}^{\mathrm{t} 3} \mathrm{Pc}^{\mathrm{g}} \mathrm{P}^{\mathrm{d}} \mathrm{Tj}^{\mathrm{g} 1} \mathrm{P}^{\dot{\mathrm{E}}} \mathrm{YVi}$; om. $\mathrm{A}^{\mathrm{d}} \mathrm{Tv}^{\mathrm{m}}$ amūn] $\mathrm{A}^{\dot{\mathrm{d}}} \mathrm{B}^{\mathrm{d} 1} \mathrm{~B}^{\mathrm{d} 2} \mathrm{~B}^{\text {s }} \mathrm{Jai}^{\mathrm{d}} \mathrm{Je}^{\mathrm{d}} \mathrm{K}^{\mathrm{d} 1}$ $\mathrm{K}^{\mathrm{d} 2} \mathrm{Pc}^{\mathrm{g}} \mathrm{P}^{\mathrm{d}} \mathrm{Tj}^{\mathrm{g} 1} \mathrm{Tv}^{\mathrm{m}} \mathrm{P}^{\mathrm{E}}$; om. My ${ }^{\mathrm{t} 3}$ YVi viśeșān] $\mathrm{A}^{\mathrm{d}} \mathrm{B}^{\mathrm{d} 1} \mathrm{~B}^{\mathrm{d} 2} \mathrm{Jai}^{\mathrm{d}} \mathrm{Je}^{\mathrm{d}} \mathrm{K}^{\mathrm{d} 1} \mathrm{~K}^{\mathrm{d} 2} \mathrm{My}^{\mathrm{t} 3}$ $\mathrm{Pc}^{\mathrm{g}} \mathrm{P}^{\mathrm{d}} \mathrm{Tj}^{\mathrm{g} 1} \mathrm{TV}^{\mathrm{m}} \mathrm{P}^{\mathrm{E}} \mathrm{YVi}$; om. $\mathrm{B}^{\mathrm{s}}$ abhiplavate] $\mathrm{A}^{\mathrm{d}} \mathrm{My}^{\mathrm{t} 3} \mathrm{Pc}^{\mathrm{g}} \mathrm{Tj}^{\mathrm{g} 1} \mathrm{YVi}$; anuplavate $\mathrm{Tv}^{\mathrm{m}}$; abhiplavate atha ko 'yam parināmah $\mathrm{B}^{\mathrm{d} 1} \mathrm{~B}^{\mathrm{d} 2} \mathrm{~B}^{\mathrm{s}} \mathrm{Jai}^{\mathrm{d}} \mathrm{Je}^{\mathrm{d}} \mathrm{K}^{\mathrm{d} 1} \mathrm{~K}^{\mathrm{d} 2} \mathrm{P}^{\mathrm{d}} \mathrm{P}^{\mathrm{E}}$ avasthitasya] $\mathrm{A}^{\mathrm{d}} \mathrm{B}^{\mathrm{d} 1} \mathrm{~B}^{\mathrm{d} 2} \mathrm{~B}^{\hat{s}} \mathrm{Jai}^{\mathrm{d}} \mathrm{Je}^{\mathrm{d}} \mathrm{K}^{\mathrm{d} 1} \mathrm{~K}^{\mathrm{d} 2} \mathrm{My}^{\mathrm{t} 3} \mathrm{Pc}^{\mathrm{g}} \mathrm{P}^{\mathrm{d}} \mathrm{Tj}^{\mathrm{g} 1} \mathrm{P}^{\mathrm{E}} \mathrm{YVi}$; avasthita $\mathrm{Tv}^{\mathrm{m}}$ dravyasya] $\mathrm{A}^{\mathrm{d}} \mathrm{B}^{\mathrm{d} 1} \mathrm{~B}^{\mathrm{d} 2} \mathrm{~B}^{\mathrm{s}} \mathrm{Jai}^{\mathrm{d}} \mathrm{K}^{\mathrm{d} 1} \mathrm{~K}^{\mathrm{d} 2} \mathrm{My}^{\mathrm{t} 3} \mathrm{Tj}^{\mathrm{g} 1} \mathrm{Tv}^{\mathrm{m}} \mathrm{P}^{\mathrm{E}} \mathrm{YVi}$; dharmasya Je ${ }^{\mathrm{d}}$ $\mathrm{Pc}^{\mathrm{g}} \mathrm{P}^{\mathrm{d}}$ iti] $\mathrm{A}^{\mathrm{d}} \mathrm{B}^{\mathrm{d} 1} \mathrm{~B}^{\mathrm{d} 2} \mathrm{~B}^{\mathrm{s}} \mathrm{Jai}^{\mathrm{d}} \mathrm{Je}^{\mathrm{d}} \mathrm{K}^{\mathrm{d} 1} \mathrm{~K}^{\mathrm{d} 2} \mathrm{My}^{\mathrm{t} 3} \mathrm{Pc}^{\mathrm{g}} \mathrm{Tj}^{\mathrm{g} 1} \mathrm{Tv}^{\mathrm{m}} \mathrm{P}^{\mathrm{E}} \mathrm{YVi}$; om. $\mathrm{P}^{\mathrm{d}}$

\section{References}

\section{Primary Sources and Abbreviations}

Abhidharmadīpa. Padmanabhi S. Jaini (ed.). Abhidharmadīpa with Vibhāshāprabhā[v]rtti. Critically edited with notes and introduction. Patna: Kashi Prasad Jayaswal Research Institute, 1959.

AK Vasubandhu, Abhidharmakośakārikā 
AKBh Vasubandhu, Abhidharmakośabhāṣya

Bharț̣hari, Vākyapadīya. K. A. Subramania Iyer (ed.). Vākyapadīya of Bhartṛhari. With the Prakīnakaprakāśa of Helarāja. Kāṇụa 3,2. Poona: Deccan College, 1973.

Bhagavadgitā. The Mahābhārata. For the first time critically ed. by V.S. Sukthankar, S.K. Belvalkar et al. Vol 7: The Bhishmaparvan. Being the sixth book of the Mahābhārata. Poona: Bhandarkar Oriental Research Institute, 1947.

Chāndogya Upanișad. P. Olivelle. The early Upanishads. Annotated text and translation. New York, Oxford: Oxford University Press, 1998.

Kamalaśila, Tattvasamgrahapañjikā. E. Krishnamacharya (ed.). Tattvasangraha by Śäntarakșita. With Pañjikā by his disciple Kamalaśilla. Vol. 1. Baroda: Central Library, 1926.

Kamalaśīla, Tattvasamgrahapañjikā, Dwārikādās Śāstri (ed.). Tattvasañgraha of Ācārya Shāntarakșita. With the Commentary "Pañjikā" of Shri Kamalashīla. Vol. 2. Varanasi: Bauddha Bharati 1968.

NBh Vātsyāyana, Nyāyabhāssya

Patañjali, Pātañjalayogaśāstra. VācaspatimiśraviracitațīkāsaṃvalitaVyāsabhāṣyasametāni Pātañjalayogasūtrāṇi tathā BhojadevaviracitaRājamārtaṇ̣ābhidhavṛttisametāni Pātañjalayogasūtrāṇi. Ed. K. Ś. Āgāśe. Punyāāhyapattana: Ānandāśramamudranālaya, 1904.

Patañjali, Vyākaranamahābhāssya. Kielhorn, Franz (ed.). The Vyākarana-Mahābhāssya of Patañjali. ... 3. ed. revised and furnished with additional readings ... by ... Kasinath Vasudev Abhyankar. Vol. 1. Poona: Bhandarkar Oriental Research Institute, 1962.

PYŚ Patañjali, Pātañjalayogaśāstra

Vācaspatimiśra I., Tattvavaiśārad̄̄ see Āgāśe.

Vasubandhu, Abhidharmakośabhāșya. P. Pradhan (ed.). Abhidharmakośabhāșyam of Vasubandhu. Rev. 2. ed. Patna: K.P. Jayaswal Research Institute, 1975.

Vātsyāyana, Nyāyabhāṣya. A. Thakur (ed.). Gautamīyanyāyadarśana with Bhāṣya of Vātsyāyana. New Delhi: Indian Council of Philosophical Research, 1997.

Yaśomitra, Sphutārthābhidharmakośavyākhyyā. Dwarikadas Shastri (ed.). Abhidharmakosa and Bhāssya of Acharya Vasubandhu with Sphutārthā commentary of Ācārya Yaśomitra. Part 2: 3. and 4. Kośasthāna. Crit. ed. Varanasi: Bauddha Bharati, 1971.

Yuktidīpikā see Wezler - Motegi 1998.

Vibhāṣāprabhāvṛtti see Abhidharmadīpa.

Śankara, Pātañjalayogaśāstravivaraṇa. Polakam Sri Rama Sastri - S.R. Krishnamurthi Sastri (eds.). Pātañjala-Yogasūtra-Bhāsya-Vivarana of Śankara-Bhagavatpāda. Critically ed. with introduction. Madras: Government Oriental Manuscript Library, 1952.

YS Patañjali, Yogasūtra see Pātañjalayogaśāstra.

\section{Secondary Sources}

Bahura, G. N. (1976). Literary heritage of the rulers of Amber and Jaipur. With an index to the register of manuscripts in the pothikhana of Jaipur. $<1$. Khasmohor Collection. $>$ Jaipur: Maharaja Sawai Man Singh II Museum, City Palace.

Bhaskaran, T. (1984). Alphabetical index of Sanskrit manuscripts in the Oriental Research Institute and Manuscript Library, Trivandrum. Vol. 3: ya to șa. Trivandrum: Oriental Research Institute and Manuscript Library, University of Kerala.

Bouthillette, K.-S. (2020). Dialogue and doxography in Indian philosophy. Points of view in Buddhist, Jaina, and Advaita Vedānta traditions. London: Routledge.

Bronkhorst, J. (1985). Patañjali and the Yoga Sūtras. Studien zur Indologie und Iranistik, 10, 191-212.

Bronkhorst, J. (1994). The qualities of Sānkhya. Wiener Zeitschrift für die Kunde Südasiens 38 (Orbis Indicus, Festschrift G. Oberhammer) (pp. 309-322).

Bronkhorst, J. (2011). Language and reality. An episode in Indian thought. Transl. from the French by M. S. Allen and R. Raghunathan. Revised and with a new appendix. Leiden, Boston: Brill.

Bronkhorst, J. (2018). Abhidharma in early Mahāyāna. In: P. Harrison (Ed.), Setting out on the great way. Essays on early Mahāyāna Buddhism (pp. 119-140). Sheffield: Equinox.

Chakravarti, P. (1951). Origins and development of the Sāmkhya system of thought. Calcutta: Metropolitan Printing and Publishing House. 
Cox, C. (1995). Disputed dharmas: Early Buddhist theories on existence. An annotated translation of the section on factors dissociated from thought from Sanghabhadra's Nyāyānusara. Tokyo: The International Institute for Buddhist Studies.

Deleanu, F. (2019). Dating with procrustes: Early Pramāṇavāda chronology revisited. Bulletin of the International Institute for Buddhist Studies, 2, 11-47.

Dessein, B. (2007). The existence of factors in the three time periods: Sarvāstivāda and Madhyamaka Buddhist interpretations of difference in mode, difference in characteristic marks, difference in state and mutual difference. Acta Orientalia, 60(3), 131-150.

Edgerton, F. (1953). Buddhist Hybrid Sanskrit grammar and dictionary (Vol. 2, p. 1953). New Haven: Yale University Press.

Franco, E. (2017). Vasubandhu the unified. Journal of Indian Philosophy, 45, 961-972.

Franco, E., \& Preisendanz, K. (1995). Bhavadāsa's interpretation of Mìmāmsāsūtra 1.1 .4 and the date of the Nyāyabhāsya. Berliner Indologische Studien, 8, 81-86.

Franco, E., Preisendanz, K. (2010). "Vorwort." In: Erich Frauwallner, Die Philosophie des Buddhismus (pp. XI-XXX). 5. Aufl. Berlin: Akademie Verlag

Frauwallner, E. (1953). Geschichte der indischen Philosophie (Vol. 1). Salzburg: Otto Müller Verlag.

Frauwallner, E. (1973). Abhidharmastudien 5. Der Sarvāstivādaḥ. Eine entwicklungsgeschichtliche Studie. Wiener Zeitschrift für die Kunde Südasiens, 17, 97-121.

Freschi, E., \& Maas, Ph. A. (2017). Introduction: Conceptual reflections on adaptive reuse. In E. Freschi \& P. A. Maas (Eds.), Adaptive reuse: Aspects of creativity in South Asian cultural history (pp. 1124). Wiesbaden: Harrassowitz.

Halbfass, W. (1992). On being and what there is. Classical Vaiśeșika and the history of Indian Ontology. New York: State University of New York Press.

Jacobi, H. (1929). Über das ursprüngliche Yogasystem. Sitzungsberichte der Preußischen Akademie der Wissenschaften. Phil.-hist. Kl. (pp. 581-624).

Jambuvijaya, M. (2000). A catalogue of manuscripts in Jaisalmer Jain Bhandaras. Jaisalmer ke prācīn jain graṃthbhaṃ̣ārom kī sūcī. Delhi: Motilal Banarsidass \& Parshvanath Jain Shwetambar Trust.

Junshō, Katō. (1989). Kyōryōbu no kenkyū. Tokyo: Shunjilsha.

Kane, P.V. (1934). Gleanings from the Abhinavabhāratī of Abhinavagupta. In: Commemorative essays presented to Kashinath Bapuji Pathak (pp. 385-400). Poona: Bhandarkar Institute Press. Government Oriental Series. Class B, No. 7.

Kritzer, R. (2005). Vasubandhu and the Yogācārabhūmi. Yogācāra elements in the Abhidharmakośabhāsyya. Tokyo: The International Institute for Buddhist Studies.

Kritzer, R. (2019). Vasubandhu. In: J. A. Silk (ed.-in-chief), Brill's encyclopedia of Buddhism. Vol. 2: Lives. Leiden: Brill.

La Vallée Poussin, L. de (1936-1937). Le bouddhisme et le yoga de Patañjali. Mélanges chinois et bouddhiques, 5, 223-242.

Lamotte, E. (1988). History of Indian Buddhism. From the origins to the Śaka Era. Transl. from the French by S. Webb-Boin under the supervision of J. Dantinne. Louvaine-La-Neuve: Institute Orientaliste de Université Catholique de Louvain.

Maas, Ph. A. (2006). Samādhipāda: Das erste Kapitel des Pātañjalayogaśāstra zum ersten Mal kritisch ediert. The first chapter of the Pātañjalayogaśāstra for the first time critically edited. Aachen: Shaker.

Maas, Ph. A. (2008). 'Descent with modification': The opening of the Pātañjalayogaśästra. In: W. Slaje (ed.), Śāstrārambha. Inquiries into the preamble in Sanskrit (pp. 97-119). Wiesbaden: Harrassowitz.

Maas, Ph. A. (2010). On the written transmission of the Pātañjalayogaśāstra. In J. Bronkhorst \& K. Preisendanz (eds.), From Vasubandhu to Caitanya. Studies in Indian philosophy and its textual history (pp. 157-172). Delhi etc.: Motilal Banarsidass.

Maas, Ph. A. (2013). A concise historiography of classical yoga philosophy. In E. Franco (ed.), Periodization and historiography of Indian Philosophy (pp. 53-90). Vienna: Sammlung de Nobili.

Maas, Ph. A. (2014). Sarvāstivāda Abhidharma and the Yoga of Patañjali. A presentation held at the 17. Congress of the International Association of Buddhist Studies, Vienna on 23 August 2014. https:// tinyurl.com/jgdkxyz.

Maas, Ph. A. (2018a). "Sthirasukham Assanam": Posture and performance in classical Yoga and beyond. In K. Baier, P. A. Maas, \& K. Preisendanz (eds.), Yoga in transformation: Historical and contemporary perspectives (pp. 49-100). Vienna: Vienna University Press.

Maas, Ph. A. (2018b). Indian Medicine and Ayurveda. In A. Jones \& L. Taub (eds.), The Cambridge history of science. Ancient sciences (Vol. 1, pp. 532-549). Cambridge: Cambridge University Press. 
Maas, Ph. A. (forthcoming). "Pātañjalayogaśāstra." In: K. A. Jacobsen (ed.), Brill's encyclopedia of Hinduism. Supplementary volume. Leiden etc: Brill.

Marulasiddhaiah, G. (1984). Descriptive catalogue of Sanskrit manuscripts. Vol. 10: Vyākaraṇa, Ślpa, Ratnaśāstra, Kāmaśāstra, Arthaśāstra, Sānkkhya, Yoga, Pūrvamīmāmsā, Nyāya. Oriental Research Institute, University of Mysore.

Monier-Williams, M. (1899). A Sanskrit-English dictionary. Etymologically and philologically arranged with special reference to cognate Indo-European languages. New ed. Greatly enlarged and improved with the collaboration of E. Leumann ... C. Cappeler ... [et. al.]. Oxford: Clarendon Press.

Nambiyar, R. (1942). An alphabetical list of manuscripts in the Oriental Institute, Baroda (Vol. 1). Baroda: Oriental Institute.

O'Brien-Kop, K. (2018). Classical discourses of liberation: shared botanical metaphors in Sarvāstivāda Buddhism and the Yoga of Patañjali. Religions of South Asia, 11(2-3), 123-157.

Park, Ch. (2014). Vasubhandhu, Śrīlata and the Sautrāntika theory of seeds. Wien: Arbeitskreis für tibetische und buddhistische Studien, Universität Wien.

Plofker, K. (2009). Mathematics in India. Princeton: Princeton University Press.

Preisendanz, K. (2018). Text segmentation, chapter naming and the transmission of embedded texts in South Asia, with special reference to the medical and philosophical traditions as exemplified by the Carakasaṃhitā and the Nyāyasūtra. In: F. Bretelle-Establet, \& S. Schmitt (eds.), Pieces and parts in scientific texts (pp. 159-220). Cham: Springer.

Raghavan (1938-1939). Abhinavagupta and the Bhāṣya on the Yogasūtras. Annals of Oriental Research (Madras), 3, 2, 1-6.

Ratié, I. (forthcoming). A history of time in the Sāṃkhya tradition. In: V. Eltschinger, B. Kellner, \& E. Mills (eds.), Roads not taken. Vienna: Wiener Studien zur Tibetologie und Buddhismuskunde.

Rau, W. (1988). Bhartrharis Vākyapadīya. Vollständiger Wortindex zu den mūlakārikās. Mainz: Akademie der Wissenschaften und der Literatur.

von Rospatt, A. (1995). The Buddhist doctrine of momentariness. A survey of the origins and early phase of this doctrine up to Vasubandhu. Stuttgart: Franz Steiner.

Sastri, S. (1931). A descriptive catalogue of the Sanskrit Manuscripts in the Tanjore Mahāräja Serfoji's Marasvatī Mahāl Library Tanjore. Vaiśeșika, Nyāya, Sānikhya \& Yoga (Vol. 11). Srirangam: Sri Vani Vilas Press.

Ščerbatckoj, F. (1923). The central conception of Buddhism. London: The Royal Asiatic Society.

Schayer, S. (1938). Contributions to the problem of time in Indian philosophy. Kraków: Nakładem Polskiej Akkademii Umiejetnościs.

Schmithausen, L. (1992). A note on Vasubandhu and the Lañkāvatārasūtra. Asiatische Studien 46.1 (Études bouddhiques offertes à Jaques May) (pp. 392-397).

Sinha, B. M. (1983). Time and temporality in Sāmkhya-yoga and in Abhidharma Buddhism. New Delhi: Munshiram Manoharlal.

Wezler, A. (1987). Remarks on the Sarvasarvātmakatvavāda. In R. Mukherji (ed.), Philosophical essays. Professor Anantalal Thakur felicitation volume (pp. 166-181). Calcutta: Sanskrit Pustak Bhandar.

Wezler, A., \& Motegi, S. (1998). Yuktidīpikā. The most significant commentary on the Sāmkhyakārikā critically edited (Vol. 1). Stuttgart: Steiner.

Willemen, C., Dessein, B., \& Cox, C. (1998). Sarvāstivāda Buddhist scholasticism. Leiden etc.: Brill. Williams, P. M. (1981). On the Abhidharma ontology. Journal of Indian Philosophy, 9, 227-257.

Wujastyk, D. (2018). Some problematic yoga sūtra-s and their Buddhist background. In K. Baier, P. A. Maas, \& K. Preisendanz (eds.), Yoga in transformation: Historical and contemporary perspectives (pp. 21-47). Vienna: Vienna University Press.

Yamashita, K. (1994). Pātañjalayoga philosophy. With reference to Buddhism. Calcutta: Firma KLM.

Publisher's Note Springer Nature remains neutral with regard to jurisdictional claims in published maps and institutional affiliations. 